Universidad de Lima

Facultad de Derecho

Carrera de Derecho

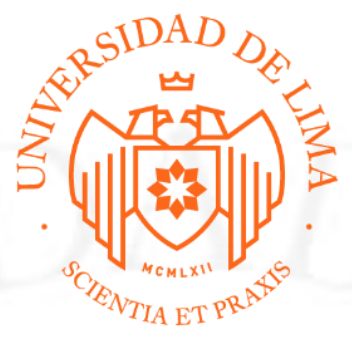

\title{
ANÁLISIS Y PROPUESTA DE MEJORA DEL ROL DEL CONCESIONARIO EN LOS PROCEDIMIENTOS DE ADQUISICIÓN Y EXPROPIACIÓN EN CONCESIONES VIALES
}

Tesis para optar el Título Profesional de Abogado

Chellscy Erika Cuenca Ramírez

Código 20111737

Asesor

Richard Martin Tirado

Lima - Perú

Junio de 2019 
A mis padres, Carlos y Erika, quienes con su amor, paciencia y esfuerzo me han permitido llegar a cumplir hoy una meta más.

A mis hermanos Octavio, Francisco y David, por su cariño y apoyo incondicional. 


\section{Agradecimientos}

Deseo agradecer a mi madre, Erika Ramírez, cuyo apoyo es constante en mi proceso formativo, y quien me acompañó de cerca en la evolución y desarrollo de la presente tesis, con mucha paciencia, comprensión y cariño, y a quien va dedicada esta tesis, en honor a su incomparable amor y su insuperable dedicación. A mi padre, Carlos Cuenca, por seguir desde siempre mis avances, y por sembrar en mis los valores que hoy me caracterizan, por sus consejos, compañía, amor y constante apoyo.

Agradezco al Dr. Richard Martin en su rol de asesor por el apoyo brindado en el desarrollo de la presente investigación.

Igualmente, agradezco al personal de la Facultad de Derecho por todo el apoyo brindado; y al de la Biblioteca de la Universidad de Lima por su amable apoyo al recopilar fuentes y bibliografía que sumaron a esta investigación.

Por último, gracias a todas las personas que me han animado en este largo camino, comprendiendo el tiempo y la dedicación que conlleva la realización de una tesis.

Mi mayor agradecimiento a todos. 


\section{ANÁLISIS Y PROPUESTA DE MEJORA DEL ROL DEL CONCESIONARIO EN LOS PROCEDIMIENTOS DE ADQUISICIÓN Y EXPROPIACIÓN EN CONCESIONES VIALES}




\section{TABLA DE CONTENIDO}

\section{INTRODUCCIÓN 11}

\section{CAPÍTULO I: DELIMITACIÓN DEL TEMA 13}

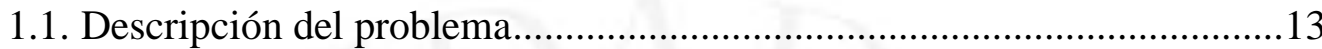

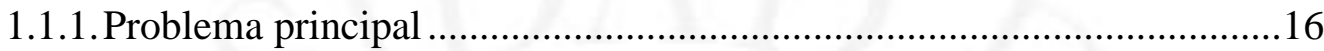

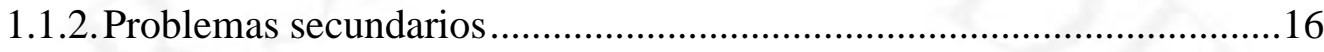

1.2. Justificación de las razones de estudio .................................................17

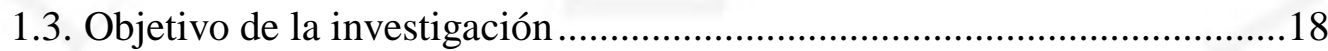

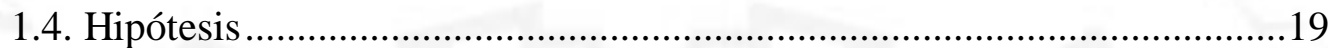

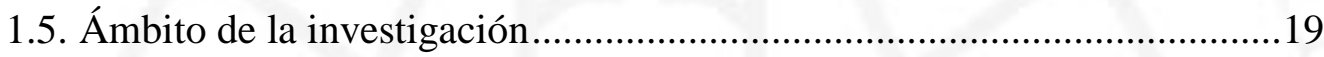

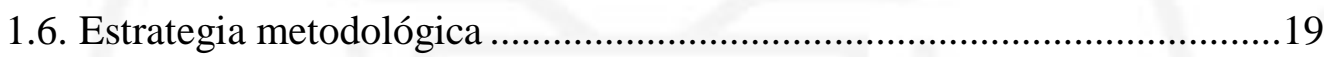

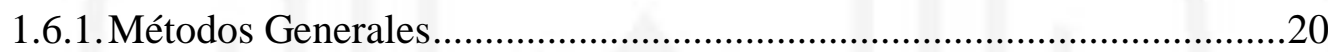

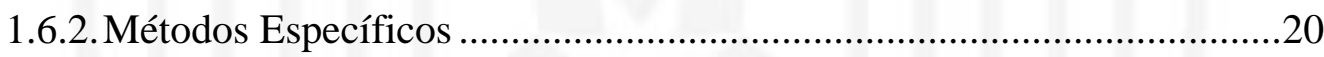

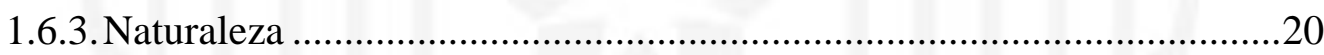

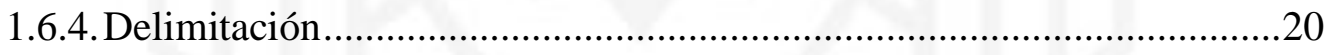

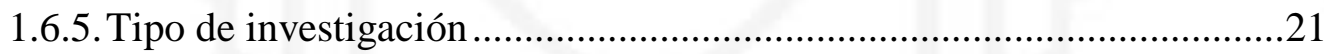

\section{CAPÍTULO II: LA GESTIÓN PREDIAL EN LAS CONCESIONES}

VIALES Y EL ROL DEL CONCESIONARIO 22

2.1 El contrato de concesión vial y la obtención de áreas concesionadas .......22

2.1.1 Cronología del marco legal del contrato de concesión vial ....................22

2.1.2. Afectación al derecho de propiedad ...................................................23

2.1.3. Diferencia entre el procedimiento de adquisición por trato directo y el procedimiento de expropiación .....................................................................28

2.1.4. Sujetos intervinientes en la obtención de predios .................................30

2.1.5. Bienes objeto de adquisición y expropiación ........................................33 
2.2. Procedimiento de obtención de áreas concesionadas .....

2.3. Cronología del procedimiento de obtención de áreas concesionadas en el Perú .38

2.4. Participación del concesionario en la adquisición de predios .45

2.4.1. Según marco legal vigente .45

2.4.2. Según contratos de concesión vial. .47

2.5. Conclusiones del Segundo Capítulo .51

CAPÍTULO III: PRINCIPALES FACTORES DE ÉXITO Y RIESGO DE LA GESTIÓN PREDIAL EN LOS CONTRATOS DE CONCESIÓN VIAL 55

3.1. Factores críticos de éxito de la gestión predial en los contratos de concesión vial. .55

3.1.1. Análisis de los factores críticos de éxito .56

3.2. Factores de riesgo de la gestión predial en los contratos de concesión vial .59

3.2.1. Factores de riesgo afrontadas en las adendas .59

3.2.2. Factores de riesgo según entrevista a expertos. 64

3.3. Asignación de los factores de riesgo de la gestión predial .68

3.3.1. Análisis a partir de los contratos de concesión vial .68

3.3.2. Análisis a partir de entrevistas a expertos . .71

3.4. Nueva asignación de los factores de riesgo de la gestión predial .73

3.4.1. Análisis a partir de los factores de riesgo considerados en los proyectos en cartera .76

3.5. Conclusiones del Tercer Capítulo .78

\section{CAPÍTULO IV: OBTENCIÓN DE PREDIOS EN LAS AMÉRICAS 80}

4.1. Infraestructura vial en América Latina. .80

4.1.1. Reflexiones .85 
4.2. Gestión predial en Chile y Colombia .......................................................86

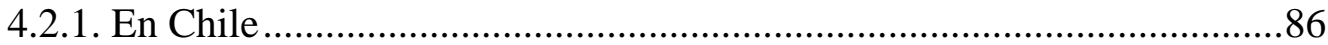

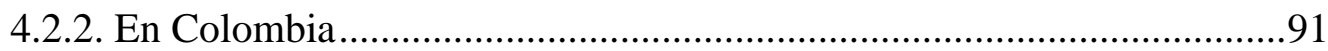

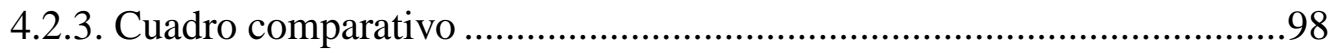

4.3. Conclusiones del Cuarto Capítulo............................................................100

CONCLUSIONES 105

RECOMENDACIONES 112 


\section{ÍNDICE DE TABLAS}

Tabla 2.1 Fases de una Asociación Público Privada 34

Tabla 2.2 Cuadro resumen de los dieciséis contratos de concesión vial vigentes. .48

Tabla 2.3 Participación de los concesionarios en los dieciséis contratos de concesión vial

Tabla 3.1 Cuadro comparativo de los procedimientos de adquisición y expropiación

Tabla 3.2 Listado de especialistas entrevistados .65

Tabla 4.1 Cuadro comparativo de la gestión predial en concesiones viales de Chile y Colombia .99 


\section{ÍNDICE DE FIGURAS}

Figura 2.1 Diagrama de flujo del procedimiento de adquisición por trato directo (Parte 1)

Figura 2.2 Diagrama de flujo del procedimiento de adquisición por trato directo

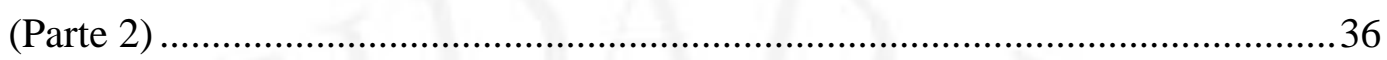

Figura 2.3 Diagrama de flujo del procedimiento de expropiación........................37

Figura 2.4 Cronología de las normas derogadas que regularon el procedimiento de expropiaciones en el Perú .40 


\section{ANEXOS}

Anexo A: Proyecto de Ley

.126 


\section{INTRODUCCIÓN}

La principal motivación para la elaboración del presente trabajo de investigación es mejorar el desarrollo de la infraestructura vial de nuestro país, desarrollo que se ha visto paralizado ante las constantes demoras en la ejecución de los proyectos viales, los mismos que se originan por las demoras en la entrega de las áreas concesionadas. Las áreas concesionadas, si no son de propiedad del Estado peruano, deben ser adquiridas a través de los procedimientos de adquisición o expropiación, los mismos que se encuentran bajo responsabilidad del mismo Estado (concedente); sin embargo, son estos procedimientos los que toman demasiado tiempo en ejecutarse. Ante esta situación, algunos inversionistas (concesionarios) optaron por suscribir adendas al contrato de concesión vial y, de esta manera, intervenir en el procedimiento de adquisición, logrando acelerar determinadas fases del mismo procedimiento.

Es por lo expuesto que el presente trabajo de investigación tiene por objetivo principal determinar las implicancias legales para asignar un nuevo rol al concesionario que optimice los procedimientos de adquisición y expropiación en los contratos de concesión vial.

En el primer capítulo de la investigación ahondamos en la descripción de la problemática descrita, desarrollaremos los objetivos de nuestra investigación, plantearemos nuestra hipótesis, y estableceremos el ámbito de investigación y la estrategia metodológica.

En el segundo capítulo, describimos la importancia del contrato de concesión vial y de la obtención de áreas concesionadas, comentamos sobre la afectación al derecho de propiedad, establecemos la principal diferencia entre el procedimiento de adquisición por trato directo y el procedimiento de expropiación, identificamos a los sujetos intervinientes en la obtención de predios e identificamos los bienes que son objeto de adquisición y expropiación. También, describimos el procedimiento que tiene el Estado peruano para obtener la titularidad de las áreas concesionadas, desarrollamos la cronología del procedimiento de la obtención de las áreas concesionadas en el Perú, y 
describimos la participación del concesionario en el procedimiento de adquisición, según marco legal peruano vigente y según contratos de concesión vial. Finalmente, presentamos las conclusiones del segundo capítulo.

En el tercer capítulo de la investigación identificamos los principales factores de éxito y riesgo de los procedimientos de adquisición y expropiación en los contratos de concesión vial, así como hemos identificado las medidas que fueron adoptadas para prevenir dichos factores de riesgo, según adendas a los contratos de concesión y entrevistas a expertos. También hemos estudiado la nueva asignación de los factores de riesgo de acuerdo a un proyecto vial en cartera. Finalmente, desarrollamos las conclusiones del tercer capítulo.

En el cuarto capítulo de la presente tesis estudiamos sobre el desarrollo de la infraestructura vial en América Latina, profundizamos nuestros estudios en materia de gestión predial de los países Chile y Colombia. Hemos elaborado un cuadro comparativo sobre las medidas adoptadas para prevenir los factores de riesgo derivados de la gestión predial en estos países. Finalmente, presentamos las conclusiones del cuarto capítulo.

Los resultados de nuestra investigación nos permitirán contribuir, desde una perspectiva jurídica, con el crecimiento y desarrollo de la infraestructura vial de nuestro país. Es por ello, que esperamos que nuestros aportes sean considerados por las entidades estatales correspondientes y sean empleados para optimizar los procedimientos de adquisición y expropiación. 


\section{CAPÍTULO I: DELIMITACIÓN DEL TEMA}

\subsection{Descripción del problema}

La economía peruana es emergente, y es una de las que lideran el crecimiento económico en la región de Latinoamérica. Estamos avanzando del sub desarrollo a la industrialización, lo que permite a sus ciudadanos tener una mejor calidad de vida; sin embargo, este crecimiento es reciente.

En los años noventa, el Perú atravesaba por una de las peores crisis económicas, sociales y políticas. La infraestructura nacional era mínima o nula y, no había empresa privada que deseara invertir en el país. La infraestructura vial se encontraba deteriorada y el país había alcanzado un crítico nivel de desarticulación e incomunicación que lo situaba al borde del colapso económico y social, pues, en ese entonces solo el $12 \%$ de la Red Vial Nacional se encontraba en buenas condiciones. (Cusato y Pastor, 2008)

El Ministerio de Transporte y Comunicaciones (MTC) ejecutó con recursos del Tesoro Público y Endeudamiento Externo, decenas de obras de rehabilitación de carreteras, puentes y aeropuertos. Se invirtieron 416 millones de dólares del Tesoro Público en obras destinadas a salvar los tramos críticos para la accesibilidad regional. Este esfuerzo que ha contado con el apoyo de Gobiernos Regionales y Municipales, ha permitido que el sistema vial del país se incremente entre los períodos 1990 y 1999 en 8092 km.: de 69,942 a 78,034. (Provias Nacional, s.f.)

La mejora en la infraestructura vial estimuló las actividades económicas en todos los sectores económicos, principalmente en minería, energía, hidrocarburos, salud, turismo, entre otros; y, se debió a la suscripción de contratos de concesión pública entre el Estado peruano e inversionistas del sector privado.

La concesión pública es una modalidad de participación de inversión privada (Asociación Público Privada). Cuando esta se vincula al sector de transporte se le denomina concesión vial. En términos generales, una concesión vial es un contrato suscrito entre el Estado y el sector privado (representado por uno o más inversionistas), por el cual, de un lado, el Estado se obliga a entregar a favor del inversionista privado un 
proyecto de infraestructura vial en concesión, por un determinado periodo de tiempo. Del otro lado, el inversionista privado se obliga a diseñar, construir, financiar, operar y/o mantener una o varias obras de infraestructura vial y a explotarla durante el periodo convenido. Finalizado dicho periodo, el inversionista privado entregará al Estado la obra de infraestructura vial según las condiciones que se hayan convenido en el contrato.

Teniendo en cuenta la necesidad del Estado peruano en seguir desarrollando su infraestructura vial, se suscribieron diversos contratos de concesión vial desde el 2003. En total, dieciséis contratos de concesión vial han sido suscritos entre el MTC (en representación del Estado peruano) e inversionistas, los mismos que se encuentran bajo la supervisión del Organismo Supervisor de la Inversión en Infraestructura de Transporte de Uso Público (OSITRAN).

Generalmente los proyectos de infraestructura vial son diseñados sobre áreas que, son de propiedad privada o se encuentra en posesión de un sujeto privado (persona natural o jurídica). Entonces, para lograr obtener la titularidad de las áreas que se encuentran bajo la propiedad de privados, necesariamente el Estado recurre a los procedimientos de adquisición por trato directo y expropiación. Para efectos de nuestra investigación, a dichos procedimientos los denominaremos gestión predial.

La gestión predial suele ser la principal traba para iniciar con la fase de construcción de las obras de infraestructura, pues, sino se cumple con obtener la titularidad de las áreas concesionadas, no se ejecuta la obra de infraestructura. Esta situación desencadena una serie de perjuicios para el concedente, el concesionario, y principalmente para los ciudadanos. Algunos perjuicios para el concedente y el concesionario son: el incremento de los costos para la ejecución del proyecto, modificación de las condiciones del contrato, incremento del plazo de vigencia, incremento de las garantías, cobro anticipado de las tarifas de peaje, rechazo social al proyecto por el cobro anticipado del peaje, entre otros. Asimismo, los ciudadanos se ven afectados por la contaminación sonora, polvo, congestión vehicular, cierre de áreas comunes, entre otros, y no pueden disfrutar de la obra de infraestructura vial según plazo estimado.

Anteriormente, las normas que regulaban la obtención de predios estaban dispersas en diversas normas. Esta situación generaba confusión entre los inversionistas e inclusive confusión en las competencias entre los actores estatales interventores. 
Entonces, con el objetivo de centralizar todos los procedimientos necesarios para la gestión predial, se publicó la Ley Marco de Adquisición y Expropiación de inmuebles, transferencia de inmuebles de propiedad del Estado, liberación de interferencias y dicta otras medidas para la ejecución de obras de infraestructura (Decreto Legislativo N ${ }^{\circ} 1192$, 2015), en adelante “D. Leg. N. ${ }^{\circ} 1192 ”$ o "Ley Marco de Adquisición y Expropiación”. Pese a ello, aun toma demasiado tiempo obtener la titularidad de las áreas concesionadas.

El D. Leg. N. ${ }^{\circ} 1192$ regula la gestión predial y otros procedimientos que permiten lograr la liberación del predio concesionado, el mismo que se divide en las siguientes etapas: Primero, para lograr obtener la titularidad del bien inmueble, se ejecuta el procedimiento de adquisición por trato directo o el procedimiento de expropiación. Segundo, si el/los ocupantes del bien inmueble no se retiran voluntariamente del bien inmueble adquirido por trato directo o expropiación, pese a haber sido correctamente compensados y notificados, se ejecuta el procedimiento de ejecución coactiva ${ }^{1}$ para lograr obtener la posesión del bien inmueble. Tercero, cuando se cuenta con la titularidad del bien inmueble y la posesión del mismo, se ejecuta el saneamiento físico legal y/o liberación de interferencias ${ }^{2}$, los mismos que se encuentran regulados por la Ley N. ${ }^{\circ}$ 26512 (2001), y, el Decreto Supremo N. ${ }^{\circ} 130-2001-E F$ (2001) y sus modificatorias.

Pese a los cambios realizados por el D. Leg. N. ${ }^{\circ} 1192$, no es fácil lograr obtener la titularidad de las áreas concesionadas. Las demoras se ven reflejadas en ocho contratos de concesión vial que no han sido culminados en los plazos convenidos, debido a la gran demora en la entrega de predios por parte del Estado peruano al concesionario. En algunos contratos, dichas demoras fueron afrontadas con medidas correctivas mediante la suscripción de adendas, por las que se encargaba al concesionario parte de las fases de

\footnotetext{
${ }^{1}$ El procedimiento de ejecución coactiva en el D. Leg. N. ${ }^{\circ} 1192$, es el procedimiento por el cual se obliga al sujeto pasivo de la gestión predial a desocupar un determinado bien inmueble, cuando este haya recibido la compensación económica que le correspondía y no haya desocupado voluntariamente el inmueble, de acuerdo a los requisitos establecidos en el Título V de la misma norma.

${ }^{2}$ Cuando el Estado logra obtener la titularidad de los predios, se debe proceder con el saneamiento y liberación de interferencias de los mismos. Por un lado, existen muchos problemas respecto a la titularidad de distintos predios, tales como problemas de duplicidad o triplicidad de partidas de inmuebles; propiedades inscritas en donde, de acuerdo a los planos inscritos, la ubicación registral no concuerda con la real; o que los ciudadanos no cuentan con su derecho de propiedad debidamente inscritos en SUNARP, por lo que se deben hacer las correcciones registrales. Por otro lado, la liberación de interferencias por servicios públicos que ya no se brindarán, también es otro factor que genera demoras. Para ejecutar la liberación de interferencias se debe coordinar el plan de retiro de dichos servicios; así como, se debe elaborar el presupuesto para realizarlo, el mismo que puede tomar meses.
} 
la gestión predial. Los concesionarios, a diferencia del concedente, lograron impulsar de forma significativa los procesos de obtención de titularidad de áreas concesionadas, ya sea identificando los bienes inmuebles, identificando a los sujetos pasivos, elaborando los expedientes técnicos o gestionando el trato directo, y con buenos resultados.

Por lo explicado, distintos funcionarios públicos y juristas han afirmado que el inversionista privado cuenta con mejores capacidades que el Estado peruano, para impulsar y gestionar de forma rápida y oportuna la obtención de la titularidad de las áreas concesionadas; sin embargo, no se ha identificado cuáles son las implicancias legales para realizar una nueva asignación de roles en los contratos de concesión vial.

\subsubsection{Problema principal}

De la problemática descrita en las líneas anteriores, y a partir de la misma, la pregunta principal de esta investigación es la siguiente:

¿Cuáles son las implicancias legales para asignar un nuevo rol al concesionario que optimice los procedimientos de adquisición y expropiación en los contratos de concesión vial?

\subsubsection{Problemas secundarios}

Asimismo, con la finalidad de ahondar en el tema y generar un conocimiento integral del mismo, la presente investigación intentará responder a las siguientes preguntas secundarias:

i. ¿Cómo se gestionan los procedimientos de adquisición y expropiación en concesiones viales según marco legal peruano vigente? ¿Qué rol tiene el concesionario en dichos procedimientos?

ii. ¿Cuáles son los principales factores de éxito y riesgos en los procedimientos de adquisición y expropiación? ¿Cómo son afrontados los factores de riesgo en los contratos de concesión vial?

iii. ¿Cuáles son los países más representativos de América, y con avances significativos, en cuanto a la legislación de gestión predial en concesiones viales? 
¿Cómo se desarrolla la gestión predial en dichos países y se afrontan los factores de riesgo anteriormente identificados?

\subsection{Justificación de las razones de estudio}

¿Por qué realizar una investigación sobre cuáles son las implicancias legales para asignar un nuevo rol al concesionario que optimice los procedimientos de adquisición y expropiación en los contratos de concesión vial?

La importancia de nuestra investigación radica en el interés que se tiene por reducir la gran brecha de infraestructura vial que aún prevalece en nuestro país y que afecta a todos sus ciudadanos. Por ello, el presente trabajo de investigación nos permitirá aportar a nuestra comunidad una posible solución alternativa frente a la demora en la obtención de áreas concesionadas; que, como mencionamos, es una problemática que se viene arrastrando desde hace muchos años y, generando pérdidas millonarias para el Estado peruano por los incumplimientos en la obligación de entrega de las áreas concesionadas; para el concesionario, quien no puede ejecutar la obra de infraestructura; y afectando principalmente a sus ciudadanos, quienes terminan pagando los sobrecostos a largo plazo, sin disfrutar de los beneficios de contar con una eficiente vía de transporte.

Según lo revisado en los contratos de concesión vial vigentes, la responsabilidad de obtener la titularidad de áreas concesionadas siempre ha sido, en todas sus fases, responsabilidad del Estado peruano; pese a que, la derogada Ley N. 27628 (2002) permitía delegar el procedimiento de adquisición por trato directo al concesionario.

Solo en algunos contratos de concesión vial, que mencionaremos más adelante, se delegó parte del procedimiento de adquisición por trato directo, como lo es la identificación del sujeto pasivo o la elaboración del expediente técnico. Con fecha posterior a la publicación del D. Leg. N. ${ }^{\circ} 1192$, el Estado y determinados concesionarios suscribieron adendas a los contratos de concesión vial, por los que el concesionario asumió la obligación de ejecutar una parte del procedimiento de adquisición que antes estaba a cargo del Estado. Los concesionarios cumplieron con dichas obligaciones y colaboraron con obtener la titularidad de predios en un periodo más breve.

Países vecinos como Chile y Colombia han optado por trasladar al concesionario, mayor responsabilidad en la gestión predial. Inclusive, en Colombia, el concesionario 
está facultado para actuar en representación del Estado colombiano en los procesos de expropiación. Estas facultades han sido otorgadas por dichos Estados recientemente, y les ha permitido avanzar mucho más rápido la gestión predial y, por tanto, ejecutar más obras de infraestructura sin interrupciones. Por los motivos expuestos, trasladar la responsabilidad de ejecutar los procedimientos de adquisición y expropiación al concesionario, podría ser la solución a la problemática descrita, siempre que estos cambios sean incorporados a la legislación peruana de manera adecuada. Sin embargo, esto lo determinaremos en el presente trabajo de investigación.

\subsection{Objetivo de la investigación}

\subsubsection{Objetivo general}

El objetivo fundamental de la presente investigación es contribuir, desde una perspectiva jurídica, con el crecimiento y desarrollo de la infraestructura vial de nuestro país, de forma tal que permita a todo aquel que revise esta tesis determinar las implicancias legales para asignar un nuevo rol al concesionario que optimice los procedimientos de adquisición y expropiación en los contratos de concesión vial.

\subsubsection{Objetivos específicos}

La presente investigación considera su desarrollo temático en torno a los siguientes objetivos específicos:

i. Comprender la gestión de los procedimientos de adquisición y expropiación en concesiones viales según marco legal peruano vigente. Así como, identificar el rol actual del concesionario en dichos procedimientos.

ii. Identificar los principales factores de éxito y riesgos en los procedimientos de adquisición y expropiación. Así como, determinar la forma en que son afrontados los factores de riesgo en los contratos de concesión vial

iii. Identificar a los países más representativos de América y con avances significativos en cuanto a la legislación de gestión predial en concesiones viales. Estudiar la gestión predial en proyectos de infraestructura vial de dichos países, e identificar las 
medidas preventivas adoptadas para afrontar los factores de riesgo de la gestión predial identificadas anteriormente.

\subsection{Hipótesis}

De acuerdo al análisis preliminar realizado sobre la materia de la presente investigación, consideramos que las implicancias legales para asignar un nuevo rol al concesionario, que optimice los procedimientos de adquisición y expropiación en los contratos de concesión vial, son realizar cambios al marco legal peruano que regula los procedimientos de adquisición y expropiación, al marco legal de las Asociaciones Público Privadas, al marco legal que regula los Planes de Adquisición, Compensación y Reasentamiento Involuntario; y, finalmente, cambios a los contratos de concesiones viales que reflejen lo normado en el marco legal peruano.

\section{5. Ámbito de la investigación}

El ámbito de la presente investigación se centra en el Derecho Administrativo, en tanto los estudios realizados sobre los procedimientos de adquisición y expropiación estudiados se centran en cada una de las principales etapas de dichos procedimientos; sin considerar los cuestionamientos en vía judicial o arbitral que pudiesen derivarse de los procedimientos de adquisición y expropiación.

\subsection{Estrategia metodológica}

La estrategia metodológica definida nos ha permitido realizar una adecuada selección del tema principal a investigar, así como de los temas secundarios que presentaremos y analizaremos; y, por los cuales, elaboraremos nuestras conclusiones a lo largo de la investigación.

La estrategia metodológica adoptada también nos permitió definir el tipo de investigación a realizar, con la finalidad de delimitar adecuadamente la temática e información obtenida. Asimismo, la estrategia metodológica permitió definir una estrategia de recolección de datos. Finalmente, la estrategia metodológica empleada nos permitió realizar un adecuado análisis de la información utilizada, con la finalidad de desarrollar 
las conclusiones y recomendaciones que aporten a la comunidad jurídica y, en especial, a nuestra sociedad.

\subsubsection{Métodos Generales}

Para ejecutar el Método General, analizaremos los resultados obtenidos del método específico.

\subsubsection{Métodos Específicos}

- Estudiaremos la normativa que regula el procedimiento de adquisición y expropiación de áreas concesionadas.

- Los contratos de concesión de infraestructura vial en los cuales haya sido necesario obtener la titularidad de los predios concesionados.

- Estudiaremos doctrina especializada y entrevistaremos a abogados especialistas en el tema de adquisiciones por trato directo y expropiaciones.

- Evaluaremos doctrina especializada nacional y doctrina especializada extranjera.

- Analizaremos los resultados de la investigación en cada capítulo.

\subsubsection{Naturaleza}

El tema de investigación elegido, procedimientos de adquisición por trato directo y expropiación, es simple, pues para obtener los resultados deseados en esta investigación requeriremos estudiar la siguiente materia: Derecho Administrativo.

\subsubsection{Delimitación}

Para la presente investigación se ha considerado las siguientes delimitaciones:

- Limitación temporal: Tendremos en consideración la regulación legal vigente desde la suscripción de los contratos de concesión vial, hasta la regulación legal vigente a la fecha de elaboración del presente trabajo de investigación.

- Limitación espacial: Tendremos en consideración las regulaciones legales nivel nacional (territorio peruano); así como de los países extranjeros (Chile y Colombia). 
- Limitación cualitativa: Estudiaremos los contratos de concesiones viales que fueron modificados con fecha posterior a la publicación del D. Leg. N. ${ }^{\circ} 1192$, y que, dicha modificación haya estado vinculada con el proceso para obtener la titularidad de las áreas concesionadas.

\subsubsection{Tipo de investigación}

La investigación desarrollada en la presente tesis es descriptiva propositiva. 


\section{CAPÍTULO II: LA GESTIÓN PREDIAL EN LAS \\ CONCESIONES VIALES Y EL ROL DEL \\ CONCESIONARIO}

\subsection{El contrato de concesión vial y la obtención de áreas concesionadas}

\subsubsection{Cronología del marco legal del contrato de concesión vial}

De acuerdo a lo desarrollado en el Capítulo I, conocemos en qué consiste una concesión vial, es por ello que ahora estudiaremos su marco legal histórico, pues nos servirá para comprender las condiciones contractuales sobre gestión predial, convenidas en los contratos de concesión vial vigentes.

Los contratos de concesión son una modalidad de Asociación Público Privada, y se rigen, por el Decreto Legislativo N. ${ }^{\circ} 1362$ (2018), Decreto Legislativo que regula la Promoción de la Inversión Privada mediante Asociaciones Público Privadas y Proyectos en Activos, y su reglamento, el Decreto Supremo N. ${ }^{\text {2 } 40-2018-E F ~(2018) . ~}$

Antes de la vigencia de las normas mencionadas, los contratos de concesión se regían por el Decreto Legislativo N. ${ }^{\circ} 1224$ (2015) y su reglamento, el Decreto Supremo N. ${ }^{\circ}$ 410-2015-EF (2015). Durante el periodo de vigencia de estas normas no se suscribieron contratos de concesión vial. Sin embargo, con anterioridad a estas normas, las concesiones se regían por el Decreto Legislativo N. ${ }^{\circ} 1012$ (2008) y su reglamento, el Decreto Supremo N. ${ }^{\text {1 }}$ 127-2014-EF (2014). Durante la vigencia de estas normas se suscribieron siete contratos de concesión vial. Finalmente, antes de la vigencia de éstas últimas, las concesiones se regían por el Decreto Supremo N. ${ }^{\circ}$ 059-96-PCM (1996), y bajo esta norma se suscribieron nueve contratos de concesión vial.

Cabe precisar que, tanto el Decreto Supremo N. ${ }^{\circ}$ 059-96-PCM (1996), como el Decreto Legislativo N. ${ }^{\circ} 1012$ (2008) y su reglamento, el Decreto Supremo N. ${ }^{\circ}$ 127-2014EF (2014), no consideraban en su regulación el procedimiento para obtener la titularidad 
de las áreas concesionadas, por tanto, los dieciséis contratos de concesión vial reflejaban esta situación. Dichos contratos serán analizados más adelante, en presente capítulo.

A diferencia de las anteriores normas que regulaban las concesiones, el Decreto Legislativo N. 1362 (2018) ha procurado estar en armonía y colaborar con la Ley Marco de Adquisición y Expropiación.

\section{Ilustración 2.1.1}

Cronología evolutiva de las normas que regularon las concesiones en el Perú

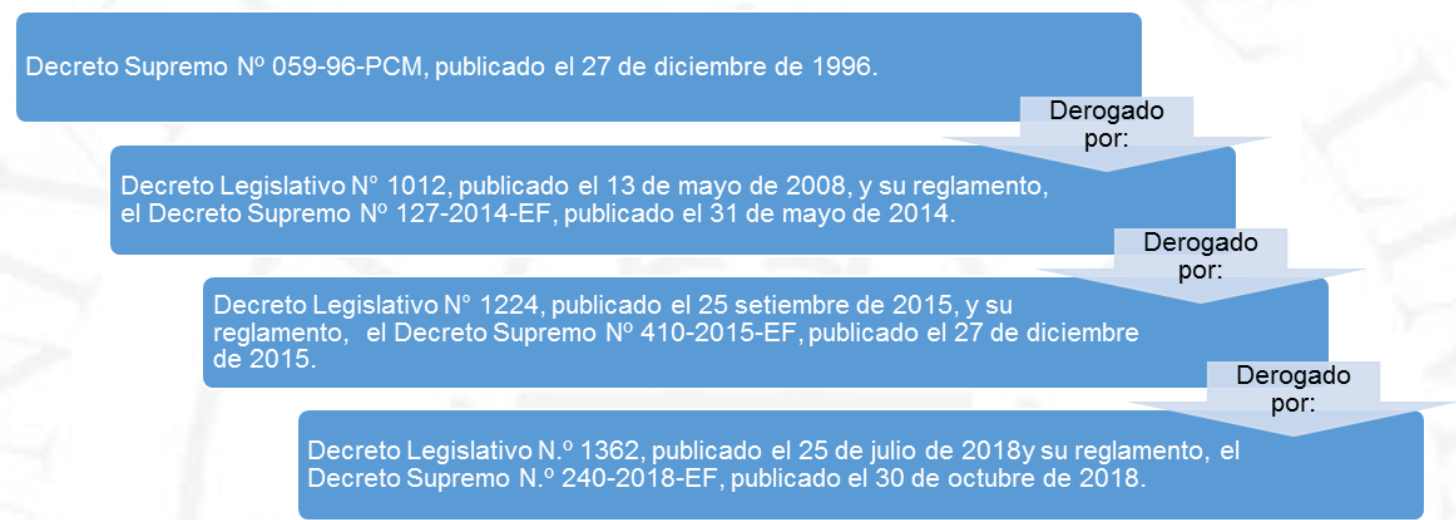

Fuente: Sistema Peruano de Información Jurídica (2019)

Elaboración propia

\subsubsection{Afectación al derecho de propiedad}

Generalmente, los proyectos de infraestructura vial han sido y son diseñados sobre áreas que son de propiedad privada, o que se encuentran en posesión de un sujeto privado (persona natural o jurídica), con el objetivo de favorecer el diseño de la infraestructura. Entonces, necesariamente los sujetos privados ven afectados su derecho de propiedad, pues el Estado recurrirá a realizar la gestión predial sobre las áreas que se encuentran afectadas por el Derecho de Vía³.

\footnotetext{
${ }^{3}$ El Derecho de Vía es la franja de terreno de ancho variable dentro del cual se encuentra comprendida la carretera, sus obras complementarias, servicios, áreas previstas para futuras obras de ensanche o mejoramiento, y zonas de seguridad para el usuario. Su ancho está establecido en la Resolución Ministerial $\mathrm{N}^{\circ}$ 218-2009-MTC/02, o norma que la sustituya. (OSITRAN, 2017, p.14)
} 
El derecho de propiedad es un derecho fundamental protegido por distintos instrumentos internacionales y en la Constitución Política del Perú.

\section{- El derecho de propiedad según Derecho Internacional Público}

La Declaración Universal de Derechos Humanos (1948) señala en su artículo 17 que: "1. Toda persona tiene derecho a la propiedad, individual y colectivamente." Y que, “2. Nadie será privado arbitrariamente de su propiedad."

Asimismo, la Declaración Americana de los Derechos y Deberes del Hombre (1948), aprobada en la Novena Conferencia Internacional Americana, Bogotá, Colombia, señala en su artículo XXIII que: "Toda persona tiene derecho a la propiedad privada correspondiente a las necesidades esenciales de una vida decorosa, que contribuya a mantener la dignidad de la persona y del hogar."

Así también, el Pacto Internacional de Derechos Económicos, Sociales y Culturales (1966), aprobado por la Asamblea General de Naciones Unidas, señala en su artículo 11 lo siguiente:

Los Estados Partes en el presente Pacto reconocen el derecho de toda persona a un nivel de vida adecuado para sí y su familia, incluso alimentación, vestido y vivienda adecuados, y a una mejora continua de las condiciones de existencia. (...)

De igual forma, en la Convención Americana Sobre Derechos Humanos (1969), aprobado en San José, Costa Rica, se prescribe el Artículo 21, sobre el derecho de propiedad privada, lo siguiente:

1. Toda persona tiene derecho al uso y goce de sus bienes. La ley puede subordinar tal uso y goce al interés social. 2. Ninguna persona puede ser privada de sus bienes, excepto mediante el pago de indemnización justa, por razones de utilidad pública o de interés social y en los casos y según las formas establecidas por la ley. (...) 
Teniendo en cuenta la regulación sobre el Derecho de Propiedad en el Derecho Internacional Público, es pertinente que el numeral 16 del artículo 2 de la Constitución Política del Perú (1993) haya definido al Derecho de Propiedad como un derecho fundamental, que no es absoluto, pues puede ser limitado para prevalecer el bien común.

\section{- EI Derecho de Propiedad en el Ordenamiento Constitucional peruano}

El Tribunal Constitucional de España, en la Sentencia N. $37 / 1987$ (1987), ha indicado que:

(...) La Constitución reconoce un derecho a la propiedad privada que se configura y protege, ciertamente, como un haz de facultades individuales sobre las cosas, pero también, y al mismo tiempo, como un conjunto de deberes y obligaciones establecidos, de acuerdo con las Leyes, en atención a valores o intereses de la colectividad, es decir, a la finalidad o utilidad social que cada categoría de bienes objeto de dominio esté llamada a cumplir. (...)(párr. 102)

Dicha concepción ha sido recogida por el Tribunal Constitucional del Perú en la Sentencia N. ${ }^{\circ}$ 0008-2003-AI/TC, por el que se sostiene que:

El derecho a la propiedad establecido en los incisos 8) y 16) del artículo $2^{\circ}$ de la Constitución, es concebido como el poder jurídico que permite a una persona usar, disfrutar, disponer y reivindicar un bien. Así, la persona propietaria podrá servirse directamente de su bien, percibir sus frutos y productos, y darle destino o condición conveniente a sus intereses, siempre que ejerza tales actividades en armonía con el bien común y dentro de los límites establecidos por la ley; e incluso podrá recuperarlo si alguien se ha apoderado de él sin derecho alguno. (núm. 26)

En ese sentido, dicha sentencia “(...) reconoce a la propiedad no sólo como un derecho subjetivo (derecho individual), sino también como una garantía institucional (reconocimiento de su función social). (núm. 26)" 
La exigencia de funcionalidad social surge de la aplicación del principio de justicia; es decir, dentro del Estado democrático y social de derecho, la propiedad no se agota en un cometido individual, sino que se despliega hasta lograr una misión social, por cuanto ésta debe ser usada también para la constitución y ensanchamiento del bien común. (Sentencia N. ${ }^{\circ}$ 0008-2003-AI/TC, 2003, núm. 26)

\section{- El Derecho de propiedad según la Constitución Política del Perú}

El artículo 70 de la Constitución (1993) delimita que el derecho de propiedad es inviolable y el Estado lo garantiza; así como, se ejerce armonía con el bien común y dentro de los límites de ley. En ese sentido, señala que a nadie se le puede privar de su propiedad sino, exclusivamente, por causa de seguridad nacional o necesidad pública.

La seguridad nacional está vinculada con "la protección a la sociedad y al Estado de las amenazas exteriores (por ejemplo, guerra con países vecinos), o internas (por ejemplo, subversión)" (Bernales, 1999, p. 46).

Respecto a la necesidad pública, debemos saber que este se trata de un concepto jurídico indeterminado; es por ello que, Víctor García Toma (1998) precisa que la necesidad pública suele estar referida a medidas o la realización de actividades que:

Redunden en beneficio, ventaja o utilidad en favor de la ciudadanía; por ejemplo, la realización de obras públicas. En puridad, en este específico aspecto hace referencia a las acciones que el Estado realiza en el campo de la construcción de infraestructura que luego pone al servicio de la población. (pp. 139-140)

Entonces, el término "necesidad pública" está vinculado a la función social. Según Castillo (2006), la función social es intrínseca al derecho de propiedad, y obliga al propietario a armonizar su interés personal con el interés social, o al menos, a estar dispuesto a que esa armonización se llegue a dar (p. 13). En ese sentido, el Tribunal Constitucional ha señalado en el Expediente N. ${ }^{\circ}$ 0008-2003-AI/TC (2003) lo siguiente:

(...) dentro del Estado democrático y social de derecho, la propiedad no se agota en un cometido individual, sino que se despliega hasta lograr una misión 
social, por cuanto ésta debe ser usada también para la constitución y ensanchamiento del bien común. El propietario dispondrá, simultáneamente, del poder de emplear su bien en procura de lograr la satisfacción de sus expectativas e intereses propios y los de su entorno familiar; y el deber de encauzar el uso y disfrute del mismo en armonía y consonancia con el bien común de la colectividad a la que pertenece. (núm. 26)

En ese sentido, Bernales (1999) afirma que: “Es de indiscutible necesidad pública la construcción de carreteras de trazo lo más recto que sea posible y para ello, muchas veces hay que expropiar propiedades ajenas, ya que están en el trazo de la nueva vía de comunicación” (p. 46).

\section{- Procedimiento que limita el derecho de propiedad}

De acuerdo a lo señalado en el artículo 70 de la Constitución (1993), para privarse a un sujeto de su derecho de propiedad, se deben seguir un procedimiento de expropiación, el mismo que debe cumplir con los siguientes requisitos:

a) Ser declarada por ley

Esta medida garantiza que las expropiaciones no se realizan de forma arbitraria por el Poder Ejecutivo, pues el Poder Legislativo controla dichos actos. Debemos precisar que el Poder Legislativo reúne pluralidad de intereses, opiniones y puntos de vista de los diversos grupos de interés y, por tanto, se presumen que las decisiones que se tomen respecto a las expropiaciones siempre estarán fundamentadas en el interés nacional y el bien común de sus ciudadanos.

b) Haberse realizado previo pago en efectivo de indemnización justificada que incluya compensación por el eventual perjuicio.

La indemnización (justipreciada) está conformada por el valor de tasación comercial del bien inmueble objeto de expropiación; así como, la indemnización 
por el eventual perjuicio, que comprende únicamente daño emergente ${ }^{4}$ y lucro cesante $^{5}$, siempre que se encuentren acreditados.

Debemos resaltar que la Constitución solo admite que el Estado peruano pague la indemnización en soles, y no en bonos o bienes como se realizaba anteriormente. Así mismo, el sujeto afectado tiene derecho a contestar el valor de la propiedad que el Estado haya señalado en el procedimiento expropiatorio, pero en ningún caso permite cuestionar la expropiación.

Sin embargo, no es la única alternativa que el Estado tiene para obtener la titularidad de un bien inmueble, pues, el artículo 76 de la Constitución (1993) establece que el Estado puede adquirir bienes (muebles o inmuebles) por contrata y licitación pública. Para ello, el titular de la propiedad debe estar de acuerdo con realizar la transferencia de su propiedad a favor del Estado peruano; así como, estar de acuerdo con el valor económico que se le pagará como indemnización (establecido por el mismo Estado). A este procedimiento se le denomina adquisición por trato directo.

Entonces, constitucionalmente, existen dos alternativas para que el Estado peruano pueda obtener el derecho de propiedad de predios que se encuentran bajo la propiedad de un sujeto privado. Estas formas de obtener la titularidad han sido desarrolladas y delimitadas en el D. Leg. N. ${ }^{\circ}$ 1192. Dichos procedimientos serán estudiados en la siguiente sección.

\subsubsection{Diferencia entre el procedimiento de adquisición por trato directo y el procedimiento de expropiación}

Los procedimientos de adquisición por trato directo y expropiación son regulados por el D. Leg. N. ${ }^{\circ} 1192$. Por medio de dichos procedimientos, el Estado peruano puede obtener

\footnotetext{
${ }^{4}$ El daño emergente corresponde al valor o precio de un bien o cosa que ha sufrido daño o perjuicio. Cuando el bien o la propiedad de una persona ha sido dañada o destruida por otra, estamos ante un daño emergente, y la indemnización en este caso será igual al precio del bien afectado o destruido.

${ }^{5}$ El lucro cesante es una forma de daño patrimonial que consiste en la pérdida de una ganancia legítima o de una utilidad económica por parte de la víctima o sus familiares como consecuencia del daño, y que ésta no se habría producido si el evento dañino no se hubiera verificado.
} 
la titularidad y/o posesión de los bienes inmuebles que forman parte de las áreas concesionadas, y que son necesarios para ser entregados en concesión.

En el numeral 4.1 del artículo 4 del D. Leg. N. ${ }^{\circ} 1192$, se define la “Adquisición” como: "La transferencia voluntaria de la propiedad del inmueble necesario para la ejecución de la Obra de Infraestructura, del sujeto pasivo a favor del Beneficiario como resultado del trato directo". Es decir, la adquisición cumple su objetivo a través del trato directo. El trato directo es un procedimiento simplificado de adquisición de un bien, que no considera todos los requisitos y formalidades propios de una licitación pública. Se trata pues de un mecanismo de compra que se emplea de manera excepcional, cuando no es posible realizar la licitación pública. Decimos que el trato directo es exitoso cuando el sujeto activo y el sujeto pasivo suscriben un "Formulario Registral", el mismo que es un contrato administrativo, entre el Estado y el sujeto privado titular del inmueble, muy similar a un contrato de compra venta.

En el numeral 4.4 del artículo 4 del D. Leg. N. ${ }^{\circ}$ 1192, se define a la expropiación como "la transferencia forzosa del derecho de propiedad privada sustentada en causa de seguridad nacional o necesidad pública, autorizada únicamente por ley expresa del Congreso de la República a favor del Estado, a iniciativa del Gobierno Nacional, Gobiernos Regionales o Gobiernos Locales y previo pago en efectivo de la indemnización justipreciada que incluya compensación por el eventual perjuicio".

La adquisición por trato directo puede suscribirse en cualquier etapa del procedimiento de obtención de titularidad de áreas concesionadas, inclusive cuando se encuentre en la fase de expropiación o de ejecución coactiva. Esta característica del procedimiento de adquisición, demuestra que el procedimiento de adquisición y el procedimiento de expropiación son independientes entre sí en cada fase. Sin embargo, el procedimiento de expropiación solo podrá iniciarse si se demuestra el rechazo al trato directo a través del procedimiento de adquisición.

En resumen, la adquisición por trato directo comprende la transferencia voluntaria de la propiedad del bien inmueble del titular hacia el Estado peruano, la misma que se logra por el trato directo entre las partes. Si es que el titular del bien inmueble se negara a aceptar la transferencia por trato directo, se procede con la expropiación. Es por este motivo que se dice que la expropiación implica una transferencia forzosa del derecho de propiedad. 


\subsubsection{Sujetos intervinientes en la obtención de predios}

El D. Leg. N. ${ }^{\circ} 1192$ identifica tres sujetos intervinientes en el procedimiento de obtención de predios: El "Sujeto Activo", el "Sujeto Pasivo" y el "Beneficiario".

\section{- Sujeto Activo}

El sujeto activo es responsable de la tramitación de los procedimientos de adquisición por trato directo (en adelante, adquisición) y expropiación. En el numeral 4.10. del artículo 4 del D. Leg. N. ${ }^{\circ} 1192$, se identifica como sujeto activo al "Ministerio competente del sector, al Gobierno Regional y al Gobierno Local". Por tanto, cuando se trate de concesiones viales, será competente el Ministerio de Transporte y Comunicaciones, el Gobierno Regional y el Gobierno Local, donde esté situada la obra de infraestructura a desarrollarse.

En la práctica, la Dirección General de Concesiones de Transportes del Ministerio de Transporte y Comunicaciones (MTC) encarga sus funciones como sujeto activo al Proyecto Especial de Infraestructura de Transporte Nacional (Provias Nacional), adscrito al MTC.

Provias Nacional ${ }^{6}$ es el encargado de ejecutar los proyectos de construcción, mejoramiento, rehabilitación y mantenimiento de la Red Vial Nacional, y cuya misión es la preparación, gestión, administración y ejecución de proyectos de infraestructura de transporte relacionada a la Red Vial Nacional, así como de la gestión y control de actividades y recursos económicos que se emplean para el mantenimiento y seguridad de las carreteras y puentes de la Red Vial Nacional. (Provias Nacional, s.f.)

\section{- Beneficiario}

De acuerdo a lo señalado en el numeral 4.2. del artículo 4 del D. Leg. N. ${ }^{\circ} 1192$, el beneficiario "es el titular del derecho de propiedad del inmueble como resultado de la

\footnotetext{
${ }^{6}$ Provias Nacional fue creado mediante Decreto Supremo Nº 033-2002- MTC del 12 de julio de 2002, Asumió todos los derechos y obligaciones del Programa Rehabilitación de Transportes (PRT), Proyecto Especial Rehabilitación Infraestructura de Transportes (PERT) y del Ex Sistema Nacional de Mantenimiento de Carreteras (SINMAC).
} 
adquisición, expropiación o transferencia de inmuebles de propiedad del Estado, necesarios para la ejecución de la Obra de infraestructura." Por tanto, el único beneficiario es el Estado actuando a través de alguna de las entidades públicas, titulares de proyectos y empresas prestadoras de servicios de saneamiento públicas de accionariado estatal o municipal.

Así también, según lo señalado en el artículo 5 de la Ley Marco de Adquisición y Expropiación, el beneficiario puede ser el mismo sujeto activo o una entidad pública distinta; pues, cuando se justifique en razones de oportunidad o eficiencia, la adquisición por trato directo y la expropiación de los inmuebles necesarios para la ejecución de Obras de Infraestructura bajo competencia de una entidad pública, pueden ser realizadas por otra entidad pública, constituyéndose la primera en beneficiario y la segunda en sujeto activo. Entonces, cuando se expropian bienes para la construcción de obras de infraestructuras otorgadas en concesión, el beneficiario de la expropiación no deja de ser el Estado.

Cualquier adquisición o expropiación a favor de persona natural o jurídica privada será nula, sin perjuicio de las acciones civiles y penales que en defensa de su derecho tiene expedito de ejercer el sujeto pasivo (D. Leg. N. $\left.{ }^{\circ} 1192,2015\right)$.

\section{- Sujeto Pasivo}

En el numeral 4.11 del artículo 4 del D. Leg. N. ${ }^{\circ} 1192$, se describe al sujeto pasivo como el propietario o poseedor del bien inmueble.

Para identificar al sujeto pasivo de bienes inmuebles inscritos, se requiere verificar que cumpla con uno de los supuestos establecidos en el artículo 6 de la Ley Marco de Adquisición y Expropiación. Y, para identificar al sujeto pasivo en bienes inmuebles no inscritos o en regímenes especiales, se sigue el procedimiento establecido en los artículos 7 y 8 de la misma Ley.

Se debe tener cuidado con la aplicación del numeral 7.2 del artículo 7 del D. Leg. N. ${ }^{\circ} 1192$, pues considera también como sujeto pasivo al poseedor con más de diez años de antigüedad, sin delimitar que esto es solo debería ser aplicable en el ámbito privado, pues los bienes de dominio privado del Estado son imprescriptibles, según lo señalado en la Ley $\mathrm{N}^{\circ} 29618$ (2010), Ley que establece la presunción de que el Estado es poseedor 
de los inmuebles de su propiedad y declara imprescriptibles los bienes inmuebles de dominio privado estatal, vigente desde el 24 de noviembre de 2010.

Entonces, surge la interrogante: ¿Qué pasa con los poseedores sobre dominio privado del Estado, cuya prescripción inicio antes de la fecha de entrada en vigencia de la Ley N. ${ }^{\circ} 29618$ ?

Según Avendaño (2014):

La prescripción iniciada antes de la fecha de entrada en vigencia de la Ley N. 29618 y que no han completado su plazo aún (o lo completarán estando vigente la Ley N. ${ }^{\circ}$ 29618), se deben aplicar las normas anteriores. (...) Si se les aplicara la Ley N. ${ }^{\circ} 29618$, y por tanto las prescripciones iniciadas no pudieran consumarse, la Ley N. ${ }^{o} 29618$ tendría efectos retroactivos, lo que la haría inconstitucional. (párr. 13).

Entonces, en el caso de las prescripciones que inician desde el 24 de noviembre de 2010, se debe aplicar la Ley N. ${ }^{\text {o }} 29618$ (2010) en forma inmediata, "porque las normas se aplican a las consecuencias de las relaciones y situaciones jurídicas existentes (artículo $103^{\circ}$ de la Constitución y artículo III del Título Preliminar del Código Civil)" (Avendaño, 2014, párr. 12).

Por tanto, la calidad de sujeto pasivo que tienen los poseedores mayores de 10 años se verá limitada por la Ley $N^{\circ} 29618$ (2010) cuando dicho periodo se contabilice a partir del 25 de noviembre de 2010.

En resumen, el D. Leg. N. ${ }^{\circ} 1192$ ha dejado fuera del concepto de sujeto pasivo a los poseedores de buena fe menor a diez años y a los propietarios que solo pueden acreditar su derecho de propiedad a través de un documento simple (contrato privado); pues, dicha norma señala que cuando no se presente algún tercero interesado o los que se presentan no acrediten su derecho de propiedad, se presume que el bien inmueble es del Estado. En estos casos el Estado obtendrá la posesión de las áreas concesionadas por medio de un proceso de desalojo a los poseedores, y solo si corresponde, un pago por las edificaciones hechas.

Para los inmuebles aportados o que forman parte de un fideicomiso, el numeral 6.6 del artículo 6 del D. Leg. N. ${ }^{\circ} 1192$ indica que, el sujeto pasivo está constituido por el 
titular del dominio fiduciario y por el titular registral del bien, con los que se deberá suscribir acuerdos de adquisición o realizar el proceso expropiatorio.

En resumen, en la gestión predial de concesiones viales, el sujeto activo está constituido por el MTC, el Gobierno Regional y el Gobierno Local de la jurisdicción en la que se ejecutará la obra de infraestructura vial, y se encargará de realizar la adquisición o expropiación; el beneficiario, es el MTC, entidad estatal a favor de la cual se efectúa la adquisición o expropiación; y, el sujeto pasivo es el titular o poseedor, con más de diez años de antigüedad y con título de posesión inscrito, del bien inmueble afectado por la adquisición o expropiación.

\subsubsection{Bienes objeto de adquisición y expropiación}

La Ley Marco de Adquisición y Expropiación señala que todos los bienes inmuebles de dominio privado son objeto de adquisición y expropiación, salvo los locales y bienes de las misiones diplomáticas, oficinas consulares y organizaciones internacionales. Estos últimos se encuentran regulados según lo dispuesto por los tratados de los que el Perú es parte y otras normas de derecho internacional. En ese sentido, tampoco se pueden expropiar bienes inmuebles de propiedad del Estado. En estos casos, solo se procede con la transferencia registral de los bienes inmuebles, según lo señalado en el Título VI del D. Leg. N. ${ }^{\circ} 1192$.

Sobre los sujetos particulares que hubiesen edificado sobre terrenos de propiedad del Estado, que no sean considerados sujetos pasivos, se procederá a desalojarlos y, solo si corresponde, se les pagará por las mejoras realizadas o edificaciones construidas o inversión realizada.

El ejercicio del derecho de propiedad relativa al uso del subsuelo y sobresuelo, se ejerce dentro de los límites establecidos en el Código Civil (1985), el D. Leg. N. ${ }^{\circ} 1192$ y las disposiciones reglamentarias que se emitan, asegurando su utilización en favor del interés público. Así mismo, la propiedad del subsuelo y sobresuelo pueden ser materia de adquisición o expropiación, independientemente del suelo.

Cuando por el hecho de la adquisición o expropiación la propiedad del inmueble sufra una desvalorización significativa o resultare inútil para los fines a que estaba destinado, el D. Leg. N. ${ }^{\circ} 1192$ señala que, el sujeto pasivo puede solicitar la adquisición 
o expropiación total, antes de que se realice la oferta de Adquisición. Esto es discutible, pues por lo establecido en el D. Leg. N. ${ }^{\circ} 1192$, “se podría considerar que una vez transcurrido el plazo establecido, el propietario ya no podría a nivel administrativo solicitar la venta del área remanente. Sin embargo, consideramos que si podría solicitarlo en sede judicial." (Soria, 2018, párr. 8).

\subsection{Procedimiento de obtención de áreas concesionadas}

\section{Tabla 2.1}

Fases de una Asociación Público Privada

\begin{tabular}{|l|l|}
\hline \multicolumn{4}{|c|}{ Fases de una Asociación Público Privada } \\
\hline $\begin{array}{l}\text { Planeamiento y } \\
\text { Programación }\end{array}$ & $\begin{array}{l}\text { Programación comprende la planificación de los proyectos, } \\
\text { correspondientes a Asociaciones Público Privadas. } \\
\text { La fase de Planeamiento y programación culmina con la aprobación del } \\
\text { Informe Multianual de Inversiones en Asociaciones Público Privadas. }\end{array}$ \\
\hline Formulación & $\begin{array}{l}\text { Comprende el diseño y/o evaluación del proyecto. } \\
\text { La fase de Formulación culmina con la incorporación del proyecto al } \\
\text { proceso de promoción. }\end{array}$ \\
\hline Estructuración & $\begin{array}{l}\text { Comprende el diseño del proyecto como Asociación Público Privada, } \\
\text { incluida su estructuración económico financiera, mecanismo de retribución } \\
\text { en caso corresponda, asignación de riesgos y diseño del contrato. } \\
\text { La estructuración está a cargo del Organismo Promotor de la Inversión } \\
\text { Privada, en coordinación con la entidad pública titular del proyecto, con el } \\
\text { organismo regulador, de corresponder, y con el Ministerio de Economía y } \\
\text { Finanzas. } \\
\text { La fase de Estructuración culmina con la publicación de la Versión Inicial } \\
\text { del contrato o de la Declaratoria de Interés, según corresponda. }\end{array}$ \\
\hline Transacción & $\begin{array}{l}\text { Comprende la apertura al mercado del proyecto. } \\
\text { La fase de Transacción culmina con la suscripción del contrato. }\end{array}$ \\
\hline Ejecución \\
Contractual & $\begin{array}{l}\text { Comprende el periodo de vigencia del contrato de Asociación Público } \\
\text { Privada, bajo responsabilidad de la entidad pública titular del proyecto. } \\
\text { La fase de Ejecución Contractual culmina con la caducidad del respectivo } \\
\text { contrato. }\end{array}$ \\
\hline
\end{tabular}

Fuente: Decreto Legislativo N. ${ }^{\circ} 1362$ (2018)

Elaboración propia

Las Asociaciones Público Privadas atraviesan por cinco fases: Planeamiento y Programación, Formulación, Estructuración, Transacción y Ejecución Contractual (D. Leg. N. ${ }^{\circ} 1362,2018$, art. 30); y, en los dieciséis contratos de concesión vial, la obtención de titularidad de áreas concesionadas se ha ejecutado en la última fase de la Asociación Público Privada, es decir, durante la fase de Ejecución Contractual. 
La fase de Ejecución Contractual de una concesión vial comprende el periodo de vigencia del contrato de concesión, y es dirigida por el concesionario bajo la supervisión del MTC. Sin embargo, la gestión predial en concesiones viales es ejecutada por el mismo Estado, bajo la denominación de sujeto activo, según lo señalado en el D. Leg. N. ${ }^{\circ} 1192$, con la posibilidad de delegar algunas etapas del procedimiento de adquisición al inversionista privado (concesionario).

El procedimiento de adquisición por trato directo está compuesto por diversas etapas y es dirigido por el sujeto activo. La adquisición inicia con la identificación de los predios afectados por el Derecho de Vía; luego, se procede a comunicar sobre dicha situación a los sujetos pasivos y ocupantes del bien inmueble. Posteriormente, se solicita ante SUNARP la anotación preventiva del bien inmueble con el fin de evitar la transferencia registral de titularidad.

Cuando se ha identificado al sujeto pasivo, se procede a elaborar el expediente técnico-legal del inmueble, en el que la principal función es realizar una inspección ocular sobre el mismo, con el objetivo de obtener la valorización preliminar del inmueble. Elaborado el expediente, se procede a realizar la tasación del inmueble con el objetivo de obtener una valorización final sobre el mismo; así como, determinar una compensación por los posibles daños e indemnizaciones (daño emergente y lucro cesante). La tasación es realizada de conformidad con lo establecido en el Reglamento Nacional de Tasaciones (Resolución Ministerial $\mathrm{N}^{\circ}$ 172-2016-VIVIENDA, 2016), por la Dirección de Construcción de la Dirección General de Políticas y Regulación en Construcción y Saneamiento del MVCS.

Luego de obtener la valorización del bien inmueble, se procede a elaborar una solicitud formal de compra, en la que se incluye, entre otros: La oferta de adquisición por el bien inmueble, según tasación, y, además, un adicional del $20 \%$ como incentivo por la entrega voluntaria y suscripción del trato directo entre el Estado y el propietario del bien inmueble. La adquisición será satisfactoria si el propietario o poseedor acepta realizar la transferencia del bien inmueble. 
Figura 2.1

Diagrama de flujo del procedimiento de adquisición por trato directo (Parte 1)

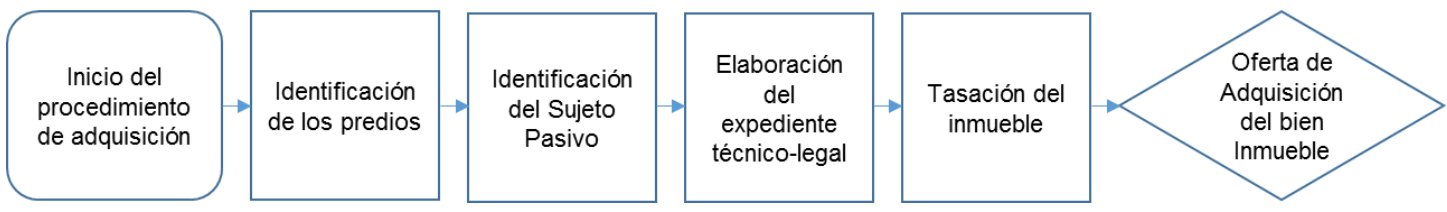

Decreto Legislativo N. ${ }^{\circ}$ 1192. (2015)

Elaboración propia

Cuando el propietario del bien inmueble acepta la oferta de compra, el sujeto activo, a través de resolución ministerial, resolución del gobernador regional (en caso de Gobiernos Regionales), o decreto de alcaldía (en caso de los Gobiernos Locales), según corresponda, aprueba el valor total de la Tasación y el pago, incluyendo el incentivo. Una vez emitida la norma mencionada, el sujeto activo deberá gestionar la suscripción del acuerdo de transferencia, por parte del propietario del bien inmueble y del sujeto activo; así como la firma de un formulario registral. También deberá realizarse el pago acordado para la entrega del bien inmueble al beneficiario.

Finalmente, una vez realizado la suscripción del formulario registral y efectuado el pago del valor total de la tasación (que incluye el incentivo), el sujeto activo procederá a solicitar en la SUNARP la transferencia de titularidad a nombre del beneficiario. De esta manera, el beneficiario obtendrá la titularidad del bien inmueble.

\section{Figura 2.2}

Diagrama de flujo del procedimiento de adquisición por trato directo (Parte 2)
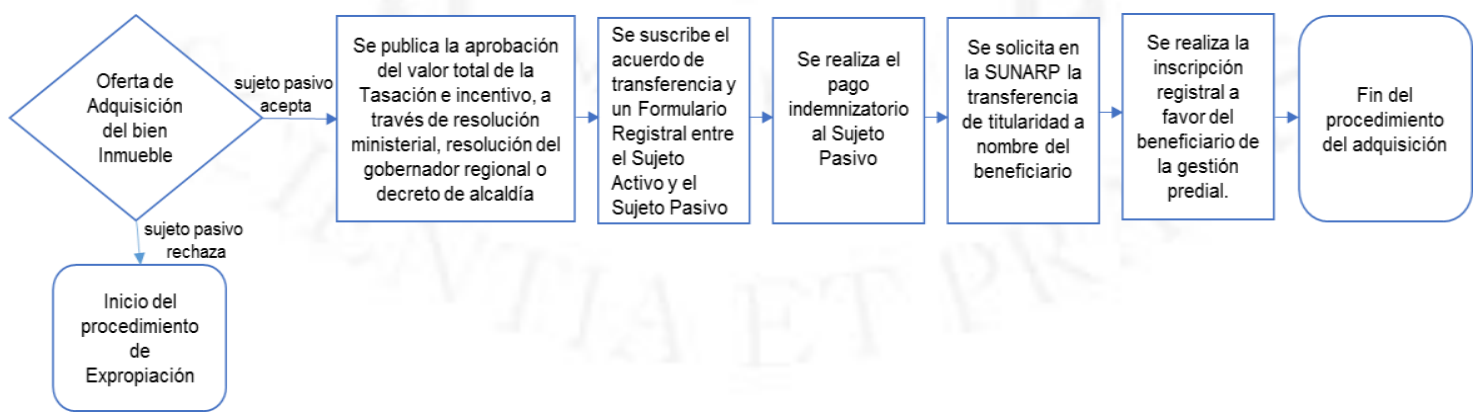

Decreto Legislativo N. ${ }^{\circ} 1192$ (2015)

Elaboración propia 
En el supuesto que el propietario del bien inmueble no se pronuncie o rechace la oferta de adquisición realizada por la administración pública, se iniciará el procedimiento de expropiación.

El procedimiento de expropiación también tiene varias etapas, la misma que inicia con el rechazo de la oferta de la adquisición. Esta condición se cumple, siempre que se haya emitido la Ley autoritativa de expropiación ${ }^{7}$. Luego, se debe publicar la norma que aprueba la ejecución de expropiación del bien inmueble y el valor de la tasación (sin considerar el incentivo), a través de la resolución ministerial; acuerdo de consejo regional (en el caso de Gobiernos Regionales); o mediante acuerdo de concejo (en caso de los Gobiernos Locales). Luego de publicada la referida norma, el sujeto activo debe realizar la consignación ${ }^{8}$ sobre el valor total de la tasación publicado.

Posteriormente, se pone en conocimiento del sujeto pasivo sobre la publicación realizada y sobre el pago de la tasación, a través de una notificación notarial o de juez de paz. Seguido a ello, se procede con la inscripción registral. De esta manera, el beneficiario obtendrá la titularidad del bien inmueble.

Figura 2.3

Diagrama de flujo del procedimiento de expropiación
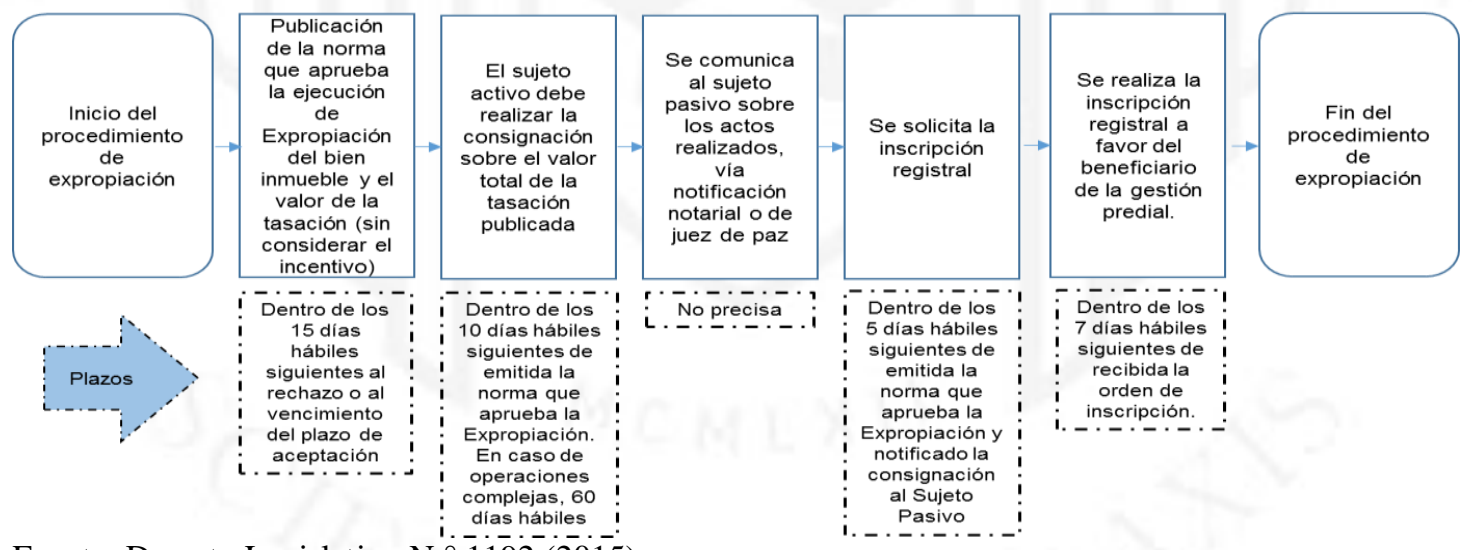

Fuente: Decreto Legislativo N. ${ }^{\circ} 192(2015)$ Elaboración propia

\footnotetext{
${ }^{7}$ La Ley autoritativa de expropiación es aquella Ley expresa del Congreso en favor del Estado que autoriza ejecutar el procedimiento de expropiación, ya sea por razón de necesidad pública o seguridad nacional.

${ }^{8}$ La consignación es un ingreso de una determinada cantidad en una cuenta bancaria. La norma no precisa sobre la forma en que se presentará la solicitud de consignación al Banco de la Nación, por lo que se presume que se debe constituir un depósito administrativo.
} 
Si vence el plazo para que el sujeto pasivo acepte el trato directo; o, si el sujeto pasivo, habiendo aceptado el trato directo no realiza la entrega del bien inmueble dentro del plazo acordado; o, si realizada la expropiación el sujeto pasivo no entrega el bien inmueble al Estado, se iniciará el procedimiento de ejecución coactiva.

Como mencionamos anteriormente, incluso, durante los procedimientos de expropiación y de ejecución coactiva, el sujeto activo se encuentra facultado para suscribir los acuerdos de adquisición, siempre que el sujeto pasivo esté de acuerdo en realizar la entrega de la posesión de los inmuebles. En dichos casos, el sujeto pasivo recibirá la indemnización con el incentivo adicional.

\subsection{Cronología del procedimiento de obtención de áreas concesionadas en el Perú}

El marco normativo de los procedimientos de adquisición y expropiaciones han permanecido en constante evolución en el tiempo. El D. Leg. N. ${ }^{\circ} 1192$ es reciente, y los contratos de concesión vial vigentes fueron suscritos cuando se encontraba en vigencia las derogadas Ley N. 27117 (1999), Ley N.o 27628 (2002), Ley N. 30025 (2013) y Ley N. 30327 (2015). Teniendo en consideración ello, es necesario estudiar las principales características de las normas en mención.

Antes de la publicación de la Ley N. ${ }^{\circ} 27117$ (1999), las expropiaciones se regían por la derogada Ley General de Expropiaciones, aprobada por el Decreto Legislativo N. ${ }^{\circ}$ 313 (1984) y su norma reglamentaria, el Decreto Supremo N. ${ }^{\circ}$ 047-85-PCM (1985), las mismas que no contenían una regulación específica sobre la aplicación de las normas de expropiación al régimen de concesiones. (Martin, 2007)

Martin (2007) nos dice que dicha omisión legal se justifica en razones históricas:

La forma tradicional de abordar los problemas de infraestructura del país, ha sido mediante el contrato de obra pública. Entonces, no debe llamar la atención, que el instituto de la expropiación haya sido ajeno al tema y, por consiguiente, no contenga normas específicas con respecto al otorgamiento de concesiones administrativas. (p. 384) 
Durante la vigencia de la norma en mención, en 1994 se suscribió el contrato de concesión vial Arequipa-Matarani, el mismo que concluyó en el 2007 con la entrega al concesionario del Tramo 5 de la Carretera Interoceánica Sur.

Con relación a la derogada Ley N. 27177 (1999), Ley General de Expropiaciones, permitía al Estado adquirir los bienes muebles, a través del trato directo, por el que se presentaba una oferta igual al monto del valor comercial actualizado del inmueble a expropiarse más un porcentaje equivalente al 5\% (cinco por ciento) de dicho valor por concepto de indemnización justipreciada.

A través de la derogada Ley N. 27628 (2002), Ley que facilita la ejecución de obras públicas viales, publicada el 09 de enero de 2002, se facultó al concesionario a efectuar el trato directo para la adquisición de los inmuebles afectados por el Derecho de Vía; sin embargo, en esta no se precisó la forma en que el procedimiento debe convenirse ni seguirse para implementar, gestionar o culminar el procedimiento de adquisición. Por tanto, el concesionario fue un mero impulsador de la gestión para la adquisición.

La derogada Ley N. ${ }^{\circ} 30025$ (2013), Ley que facilita la adquisición, expropiación y posesión de bienes inmuebles para obras de infraestructura y declara de necesidad pública la adquisición o expropiación de bienes inmuebles afectados para la ejecución de diversas obras de infraestructura, publicada el 22 mayo 2013, como su mismo nombre lo indica, reguló la obtención de inmuebles mediante la adquisición por trato directo o expropiación. Es recién con esta norma que se consideran las especificaciones necesarias para que los concesionarios puedan gestionar el trato directo; sin embargo, se seguía considerando a la adquisición como una etapa del procedimiento de expropiación.

La derogada Ley N. 30327 (2015), Ley de Promoción de las Inversiones para el Crecimiento Económico y el Desarrollo Sostenible, publicada el 21 de mayo de 2015, estableció un procedimiento especial para la obtención de terrenos que se requerían para ejecutar las obras de infraestructura vial, con el objetivo de reducir los plazos y facilitar la obtención de los bienes inmuebles concesionados. 
Figura 2.4

Cronología de las normas derogadas que regularon el procedimiento de expropiaciones en el Perú

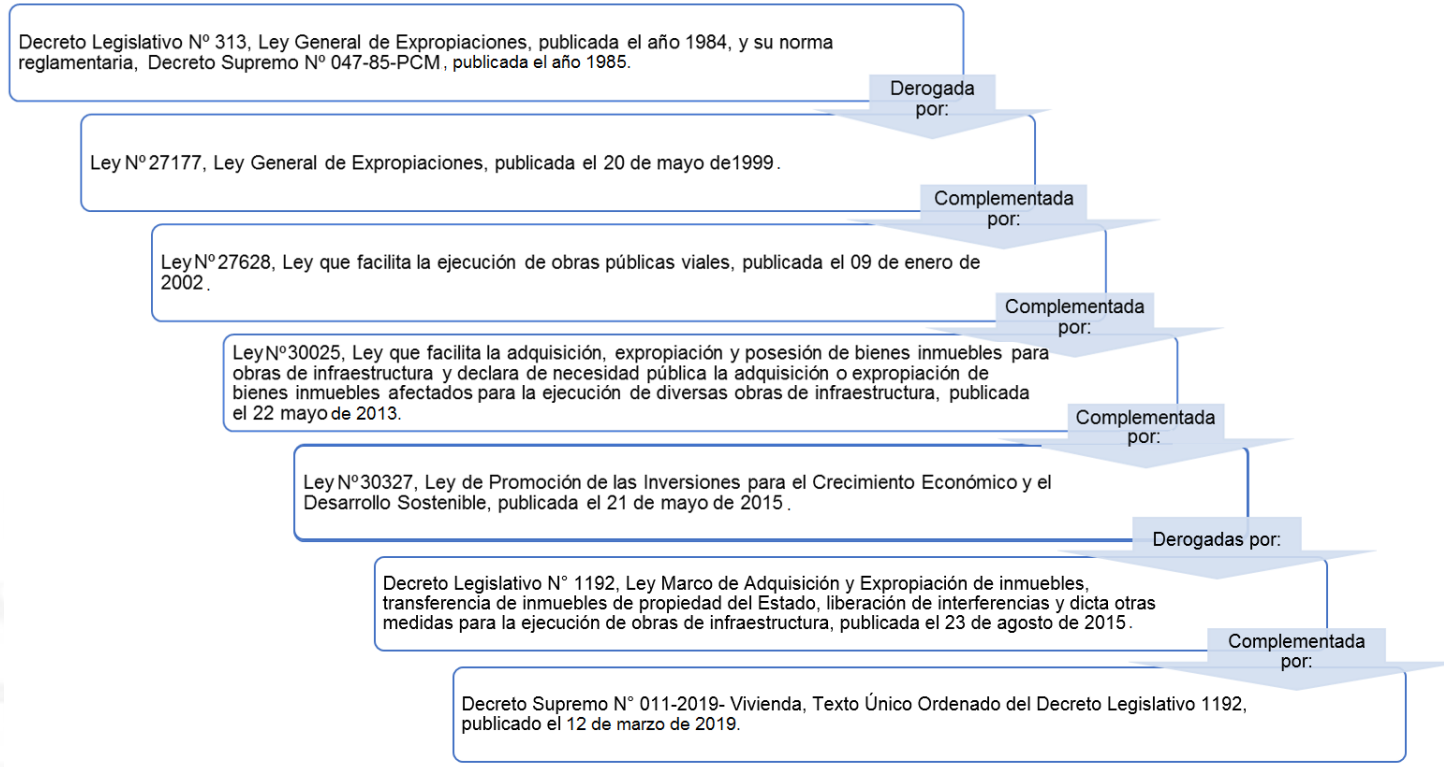

Fuente: Sistema Peruano de Información Jurídica (SPIJ), 06 de marzo de 2019.

Elaboración propia

Como podemos observar, las normas que regulaban la obtención de predios estaban dispersas en diversas normas; no tenían en consideración los principios de armonización de intereses, celeridad y eficacia, y transparencia; tampoco se distinguía la naturaleza del procedimiento de adquisición por trato directo del procedimiento de expropiación. Por tanto, con el objetivo de centralizar todos los procedimientos necesarios para la liberación de áreas concesionadas, se publicó D. Leg. N. 1192. Seguida a esta norma, se publicaron la Directiva $N^{\circ}$ 09-2015-SUNARP-SN (2015), Directiva que regula en sede registral el trámite de inscripción de los actos inscribibles referidos al proceso de adquisición y expropiación de inmuebles en el marco del D. Leg. N. ${ }^{\circ}$ 1192; Resolución N. ${ }^{\circ}$ 230-2015-SUNARP-SN (2015), Resolución que aprueba Formularios de Adquisición y de Bloqueo Registral; Directiva N. ${ }^{\circ}$ 004-2015-SBN (2015), Directiva para la inscripción y transferencia de predios estatales requeridos para la ejecución de los procedimientos establecidos en el marco del D. Leg. N. ${ }^{\circ} 1192$; Ley $\mathrm{N}^{\circ} 30230$ (2014), Ley que Establece medidas tributarias, simplificación de procedimientos y permisos para la promoción y dinamización de la inversión en el país, 
y su reglamento aprobado por Decreto Supremo N. ${ }^{\circ}$ 019-2015-VIVIENDA (2015); y, otras normas complementarias.

Cabe precisar que el D. Leg. N. ${ }^{\circ} 1192$ ha sido modificado reiteradas veces; sin embargo, los cambios más relevantes fueron realizados por el Decreto Legislativo N. ${ }^{\circ}$ 1330 (2017), publicado el 06 de enero de 2017; y, por el Decreto Legislativo N. 1366 (2018), publicado el 23 de julio de 2018. Así también, el 12 de marzo de 2019, se publicó el Decreto Supremo No 011-2019-Vivienda (2019), Texto Único Ordenado del Decreto Legislativo N. ${ }^{0} 1192$.

Los cambios realizados por el Decreto Legislativo N. 1330 (2017) fueron:

- Cambió del Organismo responsable de ejecutar las tasaciones de los bienes inmuebles. Desde un principio, el MVCS fue el responsable de efectuar las tasaciones; sin embargo, por Ley N. 30264 se encargó esta facultad a la Dirección General de Concesiones en Transportes del Ministerio de Transportes y Comunicaciones; y, a través del Decreto Legislativo N. ${ }^{\circ} 1330$ (2017), se dispuso el retorno de dicha facultad a la Dirección General de Políticas y Regulación en Construcción y Saneamiento del Ministerio de Vivienda, Construcción y Saneamiento.

- Se incrementó de $10 \%$ a $20 \%$ el valor del incentivo que el Estado otorga a los sujetos pasivos del proceso de obtención de áreas concesionadas, cuando estos aceptan realizar la transferencia del bien inmueble a través del trato directo.

- Se delimitó el concepto de domicilio.

- Se prohibió que las áreas en las que se haya iniciado el proceso de adquisición sean saneadas, con el objetivo de evitar distorsiones en el valor comercial de los predios.

- Amplió la posibilidad de suscribir los tratos directos, aun cuando los predios se encuentren en disputa en proceso judicial o arbitral; inclusive cuando los predios que hayan sido aportados formen parte de un fideicomiso.

- Considera cómo deberá actuar la administración pública en los supuestos de duplicidad de partidas. 
Dichos cambios impactaron positivamente en el proceso de obtención de áreas concesionadas. Sin embargo, no lo suficiente, pues en las Memorias Anuales de OSITRAN del año 2016 y 2017, se indica que aún persisten las demoras en la entrega de áreas concesionadas para la ejecución de obras de infraestructura vial.

Los cambios realizados por el Decreto Legislativo N. ${ }^{\circ} 1366$ (2018) fueron sobre distintas fases de la gestión predial. Los cambios más relevantes fueron:

- Con relación al beneficiario de la gestión predial, las empresas prestadoras de servicios de saneamiento públicas de accionariado estatal o municipal, podrán ser beneficiarios.

- Respecto a la inscripción de la anotación preventiva sobre el bien inmueble, hay una nueva obligación para la Superintendencia Nacional de los Registros Públicos (SUNARP), la cual una vez que inscriba la anotación preventiva, debe entregar también al sujeto activo el gráfico del área objeto de la anotación preventiva.

- La elaboración del expediente técnico legal se redujo de seis a cuatro meses.

- Referente a la identificación de los bienes inmuebles afectados por el Derecho de Vía, se prescribió que en caso el proyecto de infraestructura afecte solo una parte del predio, el sujeto pasivo solo podría solicitar la adquisición o expropiación total del bien inmueble hasta antes de la suscripción del trato directo.

- Con relación al sujeto pasivo, se establecen nuevos criterios en el artículo 245 de Código Procesal Civil (1993) para considerar un documento de fecha cierta, con el objetivo de facilitar la identificación del sujeto pasivo.

- Así también, se ha delimitado que, en caso el sujeto pasivo sea una sucesión, basta que sea inscrita definitivamente en el registro de sucesiones. Si no se encuentra inscrito en dicho registro, se considerará al titular registral como sujeto pasivo y se iniciará un procedimiento de expropiación.

- Respecto a la tasación, se ha reducido el plazo de dos meses a treinta días hábiles, contados desde la designación del perito. Así como, se precisó que para efectuar la tasación se deberá incluir el plazo de zonificación vigente.

- $\quad$ Resalta la autorización que se brinda al MTC para que pueda solicitar la elaboración de la tasación de los inmuebles ubicados en áreas concesionadas, a "Peritos u organismos especializados en el rubro, con reconocida y acreditada experiencia". Precisa que "el procedimiento de tasación se ajustará a lo 
establecido en el Reglamento Nacional de Tasaciones y la normatividad vigente"; así como, que "los organismos especializados a cargo del servicio de tasación serán solidariamente responsables con el Perito a cargo de la elaboración de la Tasación.” (Decreto Legislativo N. ${ }^{\circ}$ 1366, 2018, art. 12) Cabe precisar que, dichos criterios se encuentran establecidos en la Resolución Ministerial N. ${ }^{\text {763-2018 }}$ MTC/01; y que, el MTC solo estará facultado por un plazo de cinco años desde la publicación del Decreto Legislativo N. ${ }^{\circ} 1366$ (2018).

- Con relación a los requisitos para fijar la indemnización por perjuicio económico, se han establecido los criterios para determinar el daño emergente y lucro cesante.

- Cuando el sujeto activo desee presentar la carta de intención de adquisición, deberá contar con el Certificado Registral Inmobiliario, el mismo que le será entregado por la SUNARP en un plazo de dos días desde que fue solicitado. El plazo anterior era de cinco días.

- Finalmente, se faculta al MTC para que hasta el 28 de julio de 2021, pueda contratar los servicios de consultorías de obras y la ejecución de obras destinadas a la liberación de interferencias, bajo el marco legal de la Ley N. 30225 (2014), Ley de Contrataciones del Estado.

Como mencionamos en la sección 2.1.1, el Decreto Legislativo N. ${ }^{\circ} 1362$ (2018) ha adoptado medidas que favorecen a la gestión predial de acuerdo a lo establecido en el D. Leg. N. ${ }^{\circ} 1192$. Estas son:

- Obligar al MTC a iniciar tempranamente el proceso de identificación, adquisición, saneamiento, expropiación de predios y liberación de interferencias.

- El MTC está facultado para realizar los procesos de reubicación o reasentamiento.

- ProInversión establecerá en sus futuros Informes de Evaluación la meta respecto a la liberación de predios y las áreas que requiere el proyecto para ser adjudicado, así como a la liberación de interferencias.

- El MTC podrá destinar una partida presupuestal específica destinada a las Adquisiciones y Expropiaciones, incluso antes de la declaración de viabilidad del proyecto. 
- Para los proyectos que ameriten una mayor participación del sector privado desde fases más tempranas, se podrá hacer uso del proceso de Diálogo Competitivo9 . (Decreto Legislativo N. ${ }^{\circ}$ 1362, 2018)

En ese sentido, el Decreto Supremo N. ${ }^{\circ}$ 240-2018-EF (2018), Reglamento del Decreto Legislativo N. ${ }^{\circ}$ 1362, establece en materia de gestión predial, que:

- El MTC tiene la función de gestionar la adquisición de predios y liberación de interferencias, así como las reubicaciones o reasentamientos para el desarrollo del proyecto.

- También precisa que es responsabilidad del concedente los gastos y costos derivados de las adquisiciones y expropiaciones de inmuebles para la ejecución de infraestructura pública, reubicaciones o reasentamientos, liberación de interferencias y/o saneamiento de predios, incluso cuando dichas labores sean encargadas al inversionista en los contratos de concesión vial. Por tanto, los costos derivados de las Adquisiciones y Expropiaciones han sido incorporados en la construcción del Flujo de Caja del proyecto.

- Al culminar la Fase de Planeamiento y Programación (primera fase de una Asociación Público Privada), el MTC deberá emitir su opinión sobre el cronograma de adquisición y/o expropiación de terrenos, reubicaciones o reasentamientos, servidumbres y liberación de interferencias, la proyección de gastos derivados de éstos y gastos por supervisión.

Finalmente, el Decreto Supremo No 011-2019-Vivienda (2019), Texto Único Ordenado del Decreto Legislativo N. ${ }^{\circ}$ 1192, ha procurado sistematizar la gestión predial, y para ello ha unificado el Decreto Legislativo N. ${ }^{o} 1192$ (2015), con las modificatorias realizadas por los Decreto Legislativo N. ${ }^{\circ} 1012(2015)^{10}$, Decreto Legislativo N.o 1330 (2017) y el

\footnotetext{
${ }^{9}$ A través del Diálogo Competitivo, se establece un proceso de comunicación acotado y transparente para incorporar soluciones innovadoras provenientes del sector privado y para optimizar el valor por dinero para el sector público, sobre la base de los principios de Competencia y Transparencia, conforme a los requisitos y procedimientos establecidos en el Reglamento. (Decreto Legislativo 1362, 2018, art. 44)

${ }^{10}$ Por medio de esta norma, se dispuso que el sujeto activo podía ejecutar el procedimiento de adquisición por trato directo, pero no el procedimiento de expropiación, en tierras y territorios de pueblos indígenas u
} 
Decreto Legislativo N. 1366 (2018). Sin embargo, en su artículo 12 no ha considerado lo dispuesto por la Primera Disposición Complementaria Final del Decreto Legislativo $\mathrm{N}^{\mathrm{o}}$ 1366, por la que se autoriza al MTC, por el plazo de cinco años, a solicitar la elaboración de la Tasación de los inmuebles necesarios para la ejecución de sus proyectos de infraestructura, a Peritos u organismos especializados en el rubro, con reconocida y acreditada experiencia.

\subsection{Participación del concesionario en la adquisición de predios}

\subsubsection{Según marco legal vigente}

La responsabilidad del inversionista privado respecto a las adquisiciones de áreas concesionadas se encuentra delimitada en el artículo 23 del D. Leg. N. ${ }^{\circ} 1192$. Este artículo considera distintas etapas del procedimiento de adquisición por trato directo de predios que pueden ser encargados al inversionista privado; también establece los límites para la asignación de costos; así como, precisa el procedimiento a seguir en caso el sujeto activo no logre la adquisición por Trato directo.

- Etapas del procedimiento de adquisición que podrán ser trasladados al inversionista

La fase de Estructuración (tercera fase de una asociación público privada) está a cargo de la Agencia de Promoción de la Inversión Privada (ProInversión), en coordinación con el MTC, con OSITRAN y, de corresponder, con el Ministerio de Economía y Finanzas (MEF). En esta fase se evalúa y diseña cada uno de los respectivos contratos de concesión vial, así como se determina el régimen aplicable a las adquisiciones de inmuebles por parte del inversionista. Si a la fecha de cierre del proceso de promoción de la inversión privada (suscripción del contrato de concesión vial) el Estado no puede entregar la totalidad de los predios necesarios para la ejecución del proyecto, dichos contratos pueden establecer que la elaboración de los expedientes

originarios; ni en áreas de Reserva Territorial o Reserva Indígena de Poblaciones Indígenas en Aislamiento Voluntario y/o Contacto Inicial. 
técnicos legales sea realizada por el inversionista durante la etapa de elaboración de los estudios definitivos y entregados al sujeto activo posteriormente.

Así también, el D. Leg. N. ${ }^{\circ} 1192$ permite convenir en el contrato de concesión vial que el inversionista efectúe la implementación, gestión y/o culminación del procedimiento de adquisición por trato directo. En dicho caso, el inversionista privado (concesionario) se obliga a obtener la propiedad del inmueble a favor del beneficiario, mediante adquisición.

\section{- Asignación de costos por la adquisición de predios}

En el numeral 23.4 del artículo 23 del D. Leg. N. ${ }^{\circ} 1192$, se señala que los costos derivados de la adquisición de los inmuebles afectados, a criterio de ProInversión, pueden ser: (1) asumidos por el inversionista e incorporados dentro de la oferta durante el proceso de promoción de la inversión privada; o, (2) asumidos por el titular del proyecto (sujeto activo) conforme se regule en los respectivos contratos de concesión.

El reembolso se realizará sobre los gastos realizados por el inversionista para la adquisición de los bienes inmuebles y que estén debidamente acreditados. Se establece que los gastos no deberán exceder la valorización hecha mediante tasación por el MVCS, ni el límite de reembolso señalado en el contrato de concesión.

Una vez recibida la solicitud de reembolso, el sujeto activo tiene un plazo máximo de treinta días hábiles para efectuar el reembolso. La demora en el pago del reembolso genera intereses legales.

\section{- Agotamiento del procedimiento de adquisición (sin éxito)}

Una vez que el inversionista informe el agotamiento de las gestiones para adquirir los inmuebles por adquisición o transcurrido el plazo establecido en esta norma, el sujeto activo inicia el procedimiento de expropiación. Para tales efectos, el inversionista presenta un informe sustentado al sujeto activo, en el que adjunta los documentos que acrediten el agotamiento de la adquisición por trato directo. 


\subsubsection{Según contratos de concesión vial}

A agosto de 2018 se encuentran vigentes dieciséis contratos de concesión vial, de los cuales el último de ellos fue suscrito el 28 de mayo de 2014. Por tanto, todos los contratos suscritos se basaron en las derogadas normas que regulaban el procedimiento de adquisición y expropiación. Al encontrarse paralizados la ejecución de proyectos de infraestructura vial por demoras en la adquisición y expropiación, las partes del contrato de concesión vial optaron por suscribir adendas, de las cuales, seis introdujeron algunas mejoras propuestas por el D. Leg. N. ${ }^{\circ} 1192$, las cuales son: (i) cuarta y quinta adenda del contrato de concesión vial Red Vial $\mathrm{N}^{\circ}$; ; (ii) primera y tercera adenda del contrato de concesión vial Red Vial $\mathrm{N}^{\circ} 4$; (iii) segunda adenda del contrato de concesión vial Autopista el Sol, y; (iv) primera adenda del contrato de concesión vial Quilca. 
Tabla 2.2

Cuadro resumen de los dieciséis contratos de concesión vial vigentes

\begin{tabular}{|c|c|c|c|c|c|c|c|c|c|}
\hline № & Concesión & $\begin{array}{l}\text { Entidad } \\
\text { Prestadora }\end{array}$ & Ubicación & $\begin{array}{l}\text { Fecha de } \\
\text { Suscripción }\end{array}$ & $\begin{array}{l}\text { Plazo de } \\
\text { Concesión }\end{array}$ & Modalidad & $\mathrm{Km}$ & $\begin{array}{l}\text { Número de } \\
\text { Adendas }\end{array}$ & $\begin{array}{l}\text { Fecha de } \\
\text { suscripción }\end{array}$ \\
\hline \multirow{5}{*}{1} & \multirow{5}{*}{$\begin{array}{l}\text { Red Vial N 5: Ancón- } \\
\text { Huacho-Pativilca }\end{array}$} & \multirow{5}{*}{ Norvial S.A. } & \multirow{5}{*}{ Lima } & \multirow{5}{*}{$15 / 01 / 2003$} & \multirow{5}{*}{25 años } & \multirow{5}{*}{$\begin{array}{l}\text { Autososteni } \\
\text { ble }\end{array}$} & \multirow{5}{*}{182.9} & 1 & 08/11/2004 \\
\hline & & & & & & & & 2 & $31 / 10 / 2005$ \\
\hline & & & & & & & & 3 & $13 / 06 / 2008$ \\
\hline & & & & & & & & 4 & 23/12/2015 \\
\hline & & & & & & & & 5 & 29/12/2017 \\
\hline \multirow{7}{*}{2} & \multirow{7}{*}{$\begin{array}{l}\text { IIRSA Norte: Paita- } \\
\text { Yurimaguas }\end{array}$} & \multirow{7}{*}{$\begin{array}{l}\text { Concesionaria } \\
\text { IIRSA Norte } \\
\text { S.A. (CINSA) }\end{array}$} & \multirow{7}{*}{$\begin{array}{c}\text { Piura, } \\
\text { Lambayeque } \\
\text {, Loreto, } \\
\text { Cajamarca, } \\
\text { Amazonas, } \\
\text { San Martín }\end{array}$} & \multirow{7}{*}{$17 / 06 / 2005$} & \multirow{7}{*}{25 años } & \multirow{7}{*}{ Cofinanciada } & \multirow{7}{*}{955.1} & 1 & 28/12/2005 \\
\hline & & & & & & & & 2 & 23/02/2006 \\
\hline & & & & & & & & 3 & $21 / 07 / 2006$ \\
\hline & & & & & & & & 4 & $14 / 05 / 2009$ \\
\hline & & & & & & & & 5 & 03/05/2011 \\
\hline & & & & & & & & 6 & $25 / 11 / 2014$ \\
\hline & & & & & & & & 7 & 03/07/2015 \\
\hline \multirow{4}{*}{3} & \multirow{4}{*}{$\begin{array}{l}\text { IIRSA Sur T2: Urcos- } \\
\text { Inambari }\end{array}$} & \multirow{4}{*}{$\begin{array}{l}\text { Concesionaria } \\
\text { IIRSA Sur - } \\
\text { Tramo } 2 \text { S.A. }\end{array}$} & \multirow{4}{*}{ Cusco } & \multirow{4}{*}{ 04/08/2005 } & \multirow{4}{*}{25 años } & & & 1 & 24/02/2006 \\
\hline & & & & & & Cofinanciada & 300 & 2 & $16 / 06 / 2006$ \\
\hline & & & & & & Cofinancıada & 300 & 3 & $26 / 07 / 2006$ \\
\hline & & & & & & & & 4 & $16 / 07 / 2007$ \\
\hline & & & & & & & & 1 & 24/02/2006 \\
\hline 4 & IIRSA Sur T3: Inambari- & Concesionaria & Madre de & $04 / 08 / 2005$ & 25 años & Cofinanciada & 4032 & 2 & $16 / 06 / 2006$ \\
\hline 4 & Iñapari & $\begin{array}{l}\text { IIRSA Sur- } \\
\text { Tramo } 3 \text { S.A. }\end{array}$ & Dios & $04 / 08 / 2005$ & 25 anos & Corinanciada & 403.2 & 3 & $26 / 07 / 2006$ \\
\hline & & & & & & & & 4 & $16 / 07 / 2007$ \\
\hline & & Intersur & & & & & & 1 & $01 / 03 / 2006$ \\
\hline 5 & IIRSA Sur 14: Azangaro- & Concesiones & Puno & 04/08/2005 & 25 años & Cofinanciada & 305.9 & 2 & $16 / 05 / 2006$ \\
\hline & & & & & & & & 3 & $26 / 07 / 2006$ \\
\hline 6 & $\begin{array}{l}\text { Red Vial N6: Puente } \\
\text { Pucusana-Cerro Azul-lca }\end{array}$ & $\begin{array}{c}\text { Concesionaria } \\
\text { Vial del Perú } \\
\text { S.A. } \\
\text { (COVIPERU) }\end{array}$ & Lima, Ica & 20/09/2005 & 30 años & $\begin{array}{l}\text { Autososteni } \\
\text { ble }\end{array}$ & 221.7 & 1 & 28/08/2007 \\
\hline & Empalme 1B - Buenos & Concesión & & & & & & 1 & $16 / 01 / 2008$ \\
\hline 7 & Aires Canchaque (Costa & Canchaque & Piura & 09/02/2007 & 15 años & Cofinanciada & 78.1 & 2 & $18 / 08 / 2009$ \\
\hline & - Sierra) & & & & & & & 3 & $18 / 08 / 2009$ \\
\hline 8 & IIRSA Sur T1: San Juan & Survial S A & Ica, cusco, & $23 / 10 / 2007$ & 25 años & Cofinanciada & 7576 & 1 & $22 / 10 / 2010$ \\
\hline & de Marcona-Urcos & & $\begin{array}{l}\text { Apurımac, } \\
\text { Avarıinhn }\end{array}$ & & & & $75 / .6$ & 2 & 02/06/2011 \\
\hline & IIRSA Sur T5: Matarani- & Concesionaria & Arequipa, & & & & & 1 & 01/04/2006 \\
\hline 9 & Azángaro e Ilo-Juliaca & $\begin{array}{l}\text { Vlai del sur } \\
\text { S.A. }\end{array}$ & Moquegua, & $24 / 10 / 2007$ & 25 años & Cofinanciada & 827.1 & 2 & 24/06/2011 \\
\hline & & $\begin{array}{l}\text { S.A. } \\
\text { (C.กVISIIR) }\end{array}$ & Puno & & & & & 3 & $19 / 06 / 2015$ \\
\hline & Red Vial No 4: Pativilca- & Autopista del & Lima, & & & & & 1 & 07/09/2015 \\
\hline 10 & Santa-Trujillo y Salaverry- & $\begin{array}{l}\text { Autopista del } \\
\text { Norte S.A.C. }\end{array}$ & Ancash, La & $18 / 02 / 2009$ & 25 años & $\begin{array}{l}\text { Autosostenı } \\
\text { ble }\end{array}$ & 356.2 & 2 & 22/07/2016 \\
\hline & Empalme R01N & & Libertad & & & & & 3 & 03/04/2017 \\
\hline 11 & $\begin{array}{c}\text { Óvalo Chancay / Dv. } \\
\text { Variante Pasamayo - } \\
\text { Huaral - Acos (Costa - } \\
\text { Sierra) }\end{array}$ & $\begin{array}{l}\text { Consorcio } \\
\text { Chancay-Acos } \\
\text { S.A. }\end{array}$ & Lima & 20/02/2009 & 15 años & Cofinanciada & 76.5 & 1 & $30 / 04 / 2010$ \\
\hline 12 & $\begin{array}{l}\text { Nuevo Mocupe Cayaltí - } \\
\text { Oyotun (Costa - Sierra) }\end{array}$ & $\begin{array}{c}\text { Obrainsa } \\
\text { Concesión } \\
\text { Valle del Zaña } \\
\text { S.A. }\end{array}$ & $\begin{array}{l}\text { Nuevo } \\
\text { Mocupe } \\
\text { Cayaltí - } \\
\text { Oyotún }\end{array}$ & $30 / 04 / 2009$ & 15 años & Cofinanciada & 46.8 & 1 & $18 / 04 / 2017$ \\
\hline 13 & Autopista del Sol: Trujillo- & Concesionaria & La Libertad, & $25 / 08 / 2009$ & 25 añกต & Autososteni & 475 & 1 & $08 / 01 / 2016$ \\
\hline 13 & Sullana & $\begin{array}{l}\text { Vial del Sol } \\
\text { S.A. }\end{array}$ & $\begin{array}{c}\text { Lambayeque } \\
\text {, Piura }\end{array}$ & $25 / 08 / 2009$ & 25 anos & ble & $4 / 5$ & 2 & 23/12/2016 \\
\hline 14 & $\begin{array}{l}\text { IIRSA Centro Tramo } N^{\circ} 2 \text { : } \\
\text { Puente Ricardo Palma - } \\
\text { La Oroya - Huancayo y }\end{array}$ & $\begin{array}{l}\text { Desarrollo Vial } \\
\text { de Los Andes }\end{array}$ & $\begin{array}{l}\text { Lima, Junín, } \\
\text { Cerro de }\end{array}$ & $27 / 09 / 2010$ & 25 años & Autososteni & 377 & 1 & 01/09/2014 \\
\hline 14 & $\begin{array}{c}\text { La Oroya - Dv. Cerro de } \\
\text { Pasco }\end{array}$ & $\begin{array}{l}\text { de Los Andes } \\
\text { S.A.C. }\end{array}$ & $\begin{array}{l}\text { Cerro de } \\
\text { Pasco }\end{array}$ & $27 / 0912010$ & 20 dilus & ble & $31 /$ & 2 & $12 / 01 / 2015$ \\
\hline 15 & $\begin{array}{l}\text { Panamericana Sur, } \\
\text { Desvío Quilca - La } \\
\text { Concordia }\end{array}$ & $\begin{array}{l}\text { Concesionaria } \\
\text { Peruana de } \\
\text { Vías - } \\
\text { COVINCA } \\
\text { S.A. }\end{array}$ & $\begin{array}{l}\text { Arequipa, } \\
\text { Moquegua, } \\
\text { Tacna }\end{array}$ & $30 / 01 / 2013$ & 25 años & $\begin{array}{l}\text { Autososteni } \\
\text { ble }\end{array}$ & 74 & 1 & 09/05/2016 \\
\hline 16 & $\begin{array}{l}\text { Longitudinal de la Sierra } \\
\text { Tramo 2: Ciudad de Dios- } \\
\text { Cajamarca-Chiple, } \\
\text { Cajamarca-Trujillo y Dv. } \\
\text { Chilete-Emp. PE-3N }\end{array}$ & $\begin{array}{l}\text { Concesionaria } \\
\text { Vial Sierra } \\
\text { Norte S.A. }\end{array}$ & $\begin{array}{l}\text { La Libertad, } \\
\text { Cajamarca }\end{array}$ & $28 / 05 / 2014$ & 25 años & Cofinanciada & 872 & 1 & 02/02/2018 \\
\hline
\end{tabular}

Fuente: Organismo Supervisor de la Inversión en Infraestructura de Transporte de Uso Público,

OSITRAN. (2018)

Elaboración propia 
Tabla 2.3

Participación de los concesionarios en los dieciséis contratos de concesión vial

\begin{tabular}{|c|c|c|c|c|c|}
\hline № & Nombre de la concesión & $\begin{array}{l}\text { a) El concesionario } \\
\text { podría efectuar la } \\
\text { liberación de las áreas } \\
\text { concesionadas }\end{array}$ & $\begin{array}{l}\text { b) El concesionario } \\
\text { podría elaborar los } \\
\text { expedientes técnico } \\
\text { legal. }\end{array}$ & $\begin{array}{l}\text { c) El concesionario } \\
\text { constituyó exclusivos } \\
\text { fondos de fideicomiso } \\
\text { para financiar las } \\
\text { expropiaciones }\end{array}$ & $\begin{array}{l}\text { d) El concesionario } \\
\text { acuerda la elaboración } \\
\text { de un Plan de } \\
\text { Compensanción y } \\
\text { Reasentamiento } \\
\text { Involuntario. }\end{array}$ \\
\hline 1 & $\begin{array}{c}\text { Red Vial N 5: Ancón-Huacho- } \\
\text { Pativilca }\end{array}$ & No & No & $\begin{array}{l}\text { Sí. Dicho fondo de } \\
\text { fideicomiso ascendía a } \\
\text { US } \$ 3,500,000.00 \text {. }\end{array}$ & $\begin{array}{l}\text { No se considera ni al } \\
\text { concedente ni al } \\
\text { concesionario. }\end{array}$ \\
\hline 2 & IIRSA Norte: Paita-Yurimaguas & No & No & No & $\begin{array}{l}\text { No se considera ni al } \\
\text { concedente ni al } \\
\text { concesionario. }\end{array}$ \\
\hline 3 & IIRSA Sur T2: Urcos-Inambari & $\begin{array}{c}\text { Sí, acordado mediante } \\
\text { cláusula incorporada por } \\
\text { adenda de fecha } 31 \text { de } \\
\text { julio de } 2009 .\end{array}$ & $\begin{array}{l}\text { Sí, acordado mediante } \\
\text { cláusula incorporada por } \\
\text { adenda de fecha } 31 \text { de } \\
\text { julio de } 2009 .\end{array}$ & No & $\begin{array}{l}\text { Sí. Mediante adenda al } \\
\text { contrato, con fecha } 30 \text { de } \\
\text { julio de } 2009 \text {, se acuerda } \\
\text { que el concesionario podrá } \\
\text { elaborar e implementar el } \\
\text { PCRA. }\end{array}$ \\
\hline 4 & IIRSA Sur T3: Inambari-Iñapari & $\begin{array}{l}\text { Sí, acordado mediante } \\
\text { cláusula incorporada por } \\
\text { adenda de fecha } 31 \text { de } \\
\text { julio de } 2009 .\end{array}$ & $\begin{array}{l}\text { Sí, acordado mediante } \\
\text { cláusula incorporada por } \\
\text { adenda de fecha } 31 \text { de } \\
\text { julio de } 2009 .\end{array}$ & No & $\begin{array}{l}\text { Sí. Mediante adenda al } \\
\text { contrato, con fecha } 30 \text { de } \\
\text { julio de 2009, se acuerda } \\
\text { que el concesionario podrá } \\
\text { elaborar e implementar el } \\
\text { PCRA. }\end{array}$ \\
\hline 5 & IIRSA Sur T4: Azángaro-Inambari & No & No & No & $\begin{array}{l}\text { No se considera ni al } \\
\text { concedente ni al } \\
\text { concesionario. }\end{array}$ \\
\hline 6 & $\begin{array}{l}\text { Red Vial N6: Puente Pucusana- } \\
\text { Cerro Azul-Ica }\end{array}$ & No & No & $\begin{array}{l}\text { Sí. Dicho fondo de } \\
\text { fideicomiso ascendía a } \\
\text { US } \$ 5,000,000.00 \text {. }\end{array}$ & $\begin{array}{l}\text { No se considera ni al } \\
\text { concedente ni al } \\
\text { concesionario. }\end{array}$ \\
\hline 7 & $\begin{array}{l}\text { Empalme 1B - Buenos Aires } \\
\text { Canchaque (Costa - Sierra) }\end{array}$ & No & No & No & $\begin{array}{l}\text { No se considera ni al } \\
\text { concedente ni al } \\
\text { concesionario. }\end{array}$ \\
\hline 8 & $\begin{array}{l}\text { IIRSA Sur T1: San Juan de Marcona- } \\
\text { Urcos }\end{array}$ & No & No & No & $\begin{array}{l}\text { No se considera ni al } \\
\text { concedente ni al } \\
\text { concesionario. }\end{array}$ \\
\hline 9 & $\begin{array}{l}\text { IIRSA Sur T5: Matarani-Azángaro e } \\
\text { Ilo-Juliaca }\end{array}$ & $\begin{array}{l}\text { Sí, acordado mediante } \\
\text { cláusula incorporada por } \\
\text { adenda de fecha } 19 \text { de } \\
\text { junio de } 2015 .\end{array}$ & $\begin{array}{l}\text { Sí, acordado mediante } \\
\text { cláusula incorporada por } \\
\text { adenda de fecha } 19 \text { de } \\
\text { junio de } 2015 .\end{array}$ & No & $\begin{array}{l}\text { No se considera ni al } \\
\text { concedente ni al } \\
\text { concesionario. }\end{array}$ \\
\hline 10 & $\begin{array}{c}\text { Red Vial No 4: Pativilca-Santa-Trujillo } \\
\text { y Salaverry-Empalme R01N }\end{array}$ & No & No & No & $\begin{array}{l}\text { No se considera ni al } \\
\text { concedente ni al } \\
\text { concesionario. }\end{array}$ \\
\hline 11 & $\begin{array}{c}\text { "Óvalo Chancay / Dv. Variante } \\
\text { Pasamayo - Huaral - Acos (Costa - } \\
\text { Sierra)" }\end{array}$ & $\begin{array}{c}\text { Sí, previo acuerdo con el } \\
\text { Concedente. }\end{array}$ & $\begin{array}{l}\text { Sí, acordado desde la } \\
\text { suscripciòn del contrato. }\end{array}$ & No & $\begin{array}{l}\text { No. Desde la suscripción } \\
\text { del contrato se establece } \\
\text { que el concedente } \\
\text { elaborará el PACRI. }\end{array}$ \\
\hline 12 & $\begin{array}{l}\text { Nuevo Mocupe Cayaltí - Oyotun } \\
\text { (Costa - Sierra) }\end{array}$ & No & No & No & $\begin{array}{l}\text { No se considera ni al } \\
\text { concedente ni al } \\
\text { concesionario. }\end{array}$ \\
\hline 13 & Autopista del Sol: Trujillo-Sullana & $\begin{array}{l}\text { Sí, previo acuerdo con el } \\
\text { Concedente, y acordado } \\
\text { mediante cláusula } \\
\text { incorporada por adenda } \\
\text { de fecha } 23 \text { de diciembre } \\
\text { de } 2016 \text {. }\end{array}$ & $\begin{array}{l}\text { Sí, acordado mediante } \\
\text { cláusula incorporada por } \\
\text { adenda de fecha } 19 \text { de } \\
\text { junio de } 2015 .\end{array}$ & No & $\begin{array}{l}\text { No se considera ni al } \\
\text { concedente ni al } \\
\text { concesionario. }\end{array}$ \\
\hline 14 & $\begin{array}{c}\text { IIRSA Centro Tramo No 2: Puente } \\
\text { Ricardo Palma - La Oroya - } \\
\text { Huancayo y La Oroya - Dv. Cerro de } \\
\text { Pasco }\end{array}$ & No & No & No & $\begin{array}{l}\text { No. Desde la suscripción } \\
\text { del contrato se establece } \\
\text { que el concedente } \\
\text { elaborará el PACRI. }\end{array}$ \\
\hline 15 & $\begin{array}{c}\text { "Panamericana Sur, Desvío Quilca - } \\
\text { La Concordia" }\end{array}$ & $\begin{array}{l}\text { Sí, previo acuerdo con el } \\
\text { Concedente, y acordado } \\
\text { mediante cláusula } \\
\text { incorporada por adenda } \\
\text { de fecha } 09 \text { de mayo de } \\
2016 .\end{array}$ & $\begin{array}{c}\text { Sí, acordado mediante } \\
\text { cláusula incorporada por } \\
\text { adenda de fecha } 09 \text { de } \\
\text { mayo de } 2016 .\end{array}$ & No & No \\
\hline 16 & $\begin{array}{c}\text { "Longitudinal de la Sierra Tramo 2: } \\
\text { Ciudad de Dios-Cajamarca-Chiple, } \\
\text { Cajamarca-Trujillo y Dv. Chilete-Emp. } \\
\text { PE-3N" }\end{array}$ & $\begin{array}{l}\text { Sí, previo acuerdo con el } \\
\text { Concedente. }\end{array}$ & $\begin{array}{l}\text { Sí, acordado desde la } \\
\text { suscripción del contrato. }\end{array}$ & No & No \\
\hline
\end{tabular}

Fuente: Organismo Supervisor de la Inversión en Infraestructura de Transporte de Uso Público,

OSITRAN. (2018)

Elaboración propia 
De lo analizado en los dieciséis contratos de concesión vial, hemos identificado que:

a. La responsabilidad de ejecutar la obtención y la liberación de las áreas concesionadas ${ }^{11}$ siempre ha estado a cargo del concedente, es decir, del Estado peruano. Solo en determinados contratos de concesión se señaló que el concesionario podría efectuar la liberación de las áreas concesionadas, previo acuerdo con el concedente. Para ello, el concedente debe aprobar previamente el presupuesto que proponga el concesionario y, luego de efectuada la liberación, debe reembolsar los gastos realizados por este último.

b. Con relación a la responsabilidad de elaborar los expedientes técnico legal, solo siete contratos de concesión vial brindan la posibilidad de que sea el concesionario quien los ejecute, de los cuales, solo en dos contratos se acordaron esta condición desde su suscripción; mientras que los demás contratos incorporaron esta condición años más tarde, a través de adendas.

c. Los costos de obtención de propiedades en los contratos de concesión vial siempre han sido asumidos íntegramente por el concedente; salvo en los contratos Red Vial $N^{\circ} 5$ y Red Vial $N^{\circ} 6$, por los que los concesionarios constituyeron exclusivos fondos de fideicomiso para financiar las expropiaciones. Sin embargo, si dichos fondos no fueron suficientes para adquirir la totalidad de las áreas concesionadas, el concedente debía pagar la diferencia. Cabe precisar que, en estos contratos, el concesionario no intervino en el procedimiento de adquisición ni expropiación.

d. Solo en los contratos de concesión vial IIRSA Sur T2 y IIRSA Sur T3, se encargó a los concesionarios, aunque de forma poco detallada, la elaboración e implementación de un "Plan de compensación y reasentamiento involuntario y adquisición de predios" (PCRA) o PACRI ${ }^{12}$, por el que se les obligaba: a)

11 Cabe precisar que, cuando en los contratos de concesión vial se habla de liberación de las áreas concesionadas, se hace referencia al procedimiento de gestión predial, y no al procedimiento de liberación de interferencias.

12 A través del PACRI se crean programas que permiten compensar a las familias propietarias o posesionarias de predios o viviendas que resulten afectadas por el proyecto vial; y, de ser necesario, propone la restitución de viviendas e infraestructura pública, y la reubicación de dichas viviendas.

El PACRI se encuentra regulado por el MTC a través de las Directrices para la Elaboración y Aplicación de Planes de Compensación y Reasentamiento Involuntario para Proyectos de Infraestructura de Transporte, la misma que fue redactada y publicada el enero de 2004. Por tanto, a la fecha, la misma se encuentra desactualizada. Estas Directrices tienen por finalidad uniformizar la presentación de los Planes de Compensación y Reasentamientos Involuntarios, para proyectos de infraestructura de transportes; tienen 
Identificar a los Sujetos Pasivos de la expropiación, b) elaborar los expedientes técnicos-legales para la adquisición de predios por trato directo, c) realizar la relocalización y construcción de módulos de vivienda y/o infraestructura que permitan la liberación del área de concesión y/o derecho de vía y, por ende, el normal desarrollo en la ejecución de las obras; y d) desarrollar un programa de generación de ingresos para la población directamente afectada.

Como hemos observado, la participación del concesionario en el procedimiento de adquisición de las propiedades concesionadas es mínima. De todas las fases que hay en el procedimiento de adquisición, solo algunos de los distintos concesionarios intervinieron en la identificación exacta de los terrenos a adquirir, elaboración de los expedientes técnicos e implementación del plan de compensación y reasentamiento involuntario.

Además, como mencionamos anteriormente, los contratos de concesión vial señalan que la adquisición de predios es responsabilidad del concedente, pero que podría convenirse (a futuro) que sea el concesionario quien apoye en la adquisición y gestión de liberación de áreas concesionadas. Es decir, cuando el concedente no haya cumplido con adquirir los bienes inmuebles dentro del plazo convenido los contratos.

Finalmente, tampoco se precisa en los contratos qué documentación deberán sustentar los concesionarios en caso no tuviesen éxito en la adquisición de las áreas concesionadas.

\subsection{Conclusiones del Segundo Capítulo}

De lo desarrollado en el presente capítulo, hemos logrado comprender la gestión de los procedimientos de adquisición y expropiación en las concesiones viales según marco legal vigente, y para ello hemos estudiado la Constitución Política del Perú (1993), la evolución normativa por el que atravesaron los procedimientos de adquisición y

su base legal, principalmente, en la Política Operativa del BID OP-710 sobre "Reasentamiento Involuntario" y en la Directriz Operacional del Banco Mundial OD 4.30 sobre "Reasentamiento Involuntario"; y, son obligatorias para los contratistas, concesionarios, proyectos ejecutores o entidades similares que los sustituyan respecto a las actividades. 
expropiación en los contratos de concesión vial, y su marco legal vigente, el Decreto Legislativo N. ${ }^{\circ} 1192$ (2015).

De acuerdo a la Constitución Política del Perú (1993), hemos identificado que el derecho de propiedad no es absoluto, y es posible de ser afectado con el único objetivo de lograr el bien común de la sociedad; por ello, cuando se trate de obras de infraestructura vial que requieran de determinadas áreas para ejecutar de forma óptima la obra, el Estado deberá obtener la titularidad de dichos predios, sanear y liberar interferencias. Para obtener la titularidad de las áreas concesionadas, el Estado puede actuar de dos formas: A través del procedimiento de adquisición por trato directo y el procedimiento de expropiación; que, si bien son independientes entre sí, son complementarias para lograr obtener la titularidad de las áreas concesionadas.

De acuerdo a la evolución normativa por la que atravesaron los procedimientos de adquisición y expropiación, hemos identificado que, cuando se suscribieron los dieciséis contratos de concesión vial vigentes, el marco legal de las concesiones viales no regulaba la gestión predial en su regulación, pese a que, nueve contratos se suscribieron durante la vigencia del Decreto Supremo N. ${ }^{\circ}$ 059-96-PCM (1996), y siete contratos se suscribieron durante la vigencia del Decreto Legislativo N. 1012 (2008) y su reglamento, el Decreto Supremo N. ${ }^{\circ}$ 127-2014-EF (2014). Mientras que, el marco legal de la gestión predial se rigió por las derogadas Ley N. 27117 (1999), Ley N. 27628 (2002), Ley N. ${ }^{\circ}$ 30025 (2013) y Ley N. 30327 (2015); las mismas que ofrecían un incentivo del 5\% sobre el valor económico tasado, por concepto de indemnización justipreciada (1999), facultaron al concesionario a efectuar el trato directo, considerando a esta como una fase del procedimiento de expropiación (2002), desarrollaron las condiciones para que el concesionario pueda gestionar el trato directo (2013) y se propuso la reducción de plazos en los procedimientos de adquisiciones y expropiaciones para obras de infraestructura, entre ellas las del sector vial (2015).

De acuerdo al marco legal vigente de los procedimientos de adquisición y expropiación, D. Leg. N. ${ }^{\circ}$ 1192, hemos identificado lo siguiente:

- Respecto a la identificación de los inmuebles materia de adquisición por obras de infraestructura diseñadas como Asociaciones Público Privadas, se dice que este puede iniciar a más tardar con la declaratoria de viabilidad; teniendo la posibilidad 
de iniciar a más tardar con los estudios desarrollados para la etapa de diseño del proyecto, cuando se trate de Asociaciones Público Privadas autosostenibles.

- Respecto a la identificación del sujeto pasivo, el D. Leg. N. ${ }^{\circ} 1192$ no se encuentra en armonía con la Ley N. 29618 (2010), pues no considera que, desde el 24 de noviembre de 2010, se ha declarado la imprescriptibilidad de los bienes de dominio privado del Estado, quedando pendiente esclarecer si dicha norma es aplicable para los poseedores de bienes de dominio privado del Estado cuya prescripción inicio antes de la entrada en vigencia de dicha norma.

- El D. Leg. N. 1192 no considera en su regulación el Plan de Compensación y Reasentamiento Involuntario-PACRI.

- También, hemos identificado que los nuevos cambios incorporados por el Decreto Legislativo N.o 1366 (2018) en el D. Leg. N. ${ }^{\circ}$ 1192, reducen los plazos de actuación del sujeto activo en distintas fases del procedimiento de adquisición en concesiones, tales como: La elaboración del expediente técnico legal, la tasación realizada por el MVCS, en la emisión del Certificado Registral Inmobiliario por la SUNARP, y el plazo para solicitar la adquisición total del inmueble.

- Se brindó la posibilidad de que sea el MTC el responsable de contratar a peritos y organismos especializados para realizar las valorizaciones, y por la Resolución Ministerial 763-2018-MTC/01, se establecieron los lineamientos sobre los cuales deberá ejecutar las tasaciones de los inmuebles necesarios para la ejecución de los proyectos de infraestructura vial y otros de competencia del MTC.

De acuerdo a lo estudiado sobre el marco legal vigente de las concesiones, Decreto Legislativo N. ${ }^{\circ} 1362$ (2018) y su reglamento, el Decreto Supremo N. ${ }^{\circ} 240-2018$ EF (2018), se ha identificado que se encuentran impulsando la participación de los inversionistas desde fases tempranas de la concesión, con el objetivo de optimizar el diseño del proyecto. Así como, se obliga a ProInversión a establecer metas para lograr la obtención de titularidad de predios y liberación de interferencias en los Informes de Evaluación. Finalmente, se obliga al MTC a iniciar tempranamente el proceso de identificación, adquisición y expropiación de predios; así como, faculta al MTC realizar los procesos de reubicación o reasentamiento, y a destinar una partida presupuestal específica destinada a las Adquisiciones y Expropiaciones. 
Respecto a la participación del inversionista privado (concesionario) en el procedimiento de obtención de predios, hemos identificado que:

- Según marco legal, el inversionista tiene la posibilidad de identificar predios, elaborar expedientes técnicos e impulsar la gestión del procedimiento de adquisición; solo cuando el Estado lo solicite al inversionista y/o lo convenga en los contratos de concesión vial.

- Mientras que, según los contratos de concesión vial, hemos identificado que, en el procedimiento de obtención de predios, el Estado tiene la responsabilidad total de la entrega de las áreas concesionadas. Muy pocas veces, se ha pactado el apoyo del concesionario al concedente en dicho procedimiento; y, si el Estado lo solicitó, fue cuando el Estado incumplió con los plazos de entrega de las áreas acordadas en los contratos. Además, el apoyo que el concesionario ha brindado al concedente ha sido para identificar a los sujetos pasivos, elaborar los expedientes técnicos de los inmuebles a expropiar, e implementar y ejecutar los planes de compensación y reasentamiento. 


\section{CAPÍTULO III: PRINCIPALES FACTORES DE ÉXITO Y RIESGO DE LA GESTIÓN PREDIAL EN LOS CONTRATOS DE CONCESIÓN VIAL}

\subsection{Factores críticos de éxito de la gestión predial en los contratos de concesión vial}

Mientras que se tenga que realizar adquisiciones o expropiaciones para lograr la obtención de titularidad de áreas concesionadas, siempre habrá una población a la que se le afectará el derecho de propiedad y/o posesión; por ello, debemos hacer que esta afectación sea una oportunidad para mejorar la condición de vida de su población. Es decir, que ganen tanto los ciudadanos que se verán beneficiados con la obra de infraestructura vial; así como, que ganen los ciudadanos a los cuales se les afectará su derecho de propiedad y/o posesión (los sujetos pasivos de la adquisición o expropiación). En ese sentido, consideramos que los factores de éxito de la gestión predial se encuentran estrechamente vinculados con los principios orientadores del D. Leg. N. ${ }^{\circ} 1192$, principio de armonización de intereses y principio de celeridad y eficacia.

A. Principio de armonización de intereses

Este factor de éxito debe ser perseguido por el Estado; pues, como se señala en el numeral 3.1 del artículo 3 del D. Leg. N. ${ }^{\circ} 1192$ :

(...) Las entidades públicas deberán armonizar los intereses del Estado que requieren procesos ágiles y expeditivos para desarrollar las Obras de Infraestructura necesarias para el desarrollo del país con los derechos de los Sujetos Pasivos.

B. Principio de celeridad y eficacia

De acuerdo a lo señalado en el numera 3.2 del artículo 3 del D. Leg. N. ${ }^{\circ} 1192$, los procedimientos de adquisición predial o expropiación deben ser ágiles: “(...) a fin de lograr la obtención oportuna de los bienes inmuebles, evitando actuaciones que 
constituyan meros formalismos, sin que ello releve a las autoridades del respeto al debido proceso o vulnere el ordenamiento jurídico".

Por lo expuesto, concluimos que de la gestión predial depende de dos factores muy importantes, que se encuentran estrechamente vinculados: (a) Compensar de forma justa al sujeto pasivo por la pérdida de su derecho de propiedad y/o posesión; y, (b) obtener la titularidad del área concesionada de acuerdo al debido proceso y en el periodo de tiempo más breve posible. En ese sentido, el Estado peruano debe priorizar en desarrollar y mejorar el procedimiento de obtención de predios que le es más eficiente (en el menor tiempo posible) y beneficioso para sus ciudadanos, en especial, los sujetos que verán afectado su derecho de propiedad y/o posesión.

\subsubsection{Análisis de los factores críticos de éxito}

En la presente sección analizaremos los factores de éxito mencionados en la sección anterior.

A. Compensar de forma justa al sujeto pasivo por la pérdida de su derecho de propiedad y/o posesión

El D. Leg. N. ${ }^{\circ} 1192$ considera aspectos vinculados a identificar los bienes inmuebles que se verán afectados por el Derecho de vía, identificar a los sujetos pasivos, así como elaborar los expedientes técnicos, e iniciar el trato directo, pero no considera el aspecto social, es decir, los verdaderos intereses y necesidades del sujeto pasivo.

Como en una típica negociación de contrato de compra venta, el sujeto pasivo tiene intereses que motivarían acelerar el proceso de venta de su bien inmueble al sujeto activo; es por este motivo que, para conocer estos intereses ocultos, se debe dialogar y negociar previamente con el sujeto pasivo. Es decir, no basta con la comunicación que, según el numeral 20.2, art. 20 del D. Leg. N. ${ }^{\circ}$ 1192, se debe realizar para que el sujeto pasivo decida aceptar el trato directo o no; sino, se debe concientizar al sujeto pasivo sobre los beneficios que recibirá él y su comunidad al ejecutarse una determinada obra de infraestructura vial. 
Entonces, cuando el sujeto pasivo reciba la oferta de compra, tendrá en consideración la importancia de su colaboración en la gestión predial, y habrá más posibilidades de que acepte la oferta presentada por el sujeto activo.

De acuerdo a lo mencionado en secciones anteriores, el PACRI considera dentro del su informe la elaboración de los estudios de impacto social, los mismos que aportarían en el proceso de optimización de la gestión predial. Por tanto, en aras de cumplir con el principio de armonización de intereses y de colaborar con el factor de éxito, que consiste en compensar de forma justa al sujeto pasivo por la pérdida de su derecho de propiedad, es recomendable que el PACRI sea incorporado en los contratos de concesión vial futuros.

B. Obtener la titularidad del área concesionada de acuerdo al debido proceso y en el periodo de tiempo más breve posible

De acuerdo a lo desarrollado en el capítulo anterior, tenemos claro que hay dos formas de lograr obtener la titularidad de un predio; a través del procedimiento de adquisición por trato directo o el procedimiento de expropiación. Ambos procedimientos tienen naturalezas jurídicas distintas; así como, conocemos cuales son las diferencias que existen entre ambas, según su marco legal. Sin embargo, si se desea lograr la titularidad del área concesionada en el periodo de tiempo más breve posible, deberemos priorizar uno de los procedimientos.

Teniendo en cuenta que el factor crítico de éxito es obtener la titularidad de los predios en el menor tiempo posible, procederemos realizar un análisis comparativo entre los procedimientos de adquisición y expropiación.

Cuando el Estado peruano o el concesionario han considerado un Plan de Compensación y Reasentamiento Involuntario (PACRI) para ejecutar un proyecto de infraestructura vial, la adquisición de predios por trato directo se realiza de forma rápida; pues, los sujetos pasivos tienen mayores incentivos para entregar al Estado peruano la posesión o propiedad del bien. Es decir, hay menos posibilidades de tener que recurrir a un procedimiento de ejecución coactiva para obligar al sujeto pasivo a entregar el bien inmueble. 
Sin embargo, si recurrimos al procedimiento de expropiación, además de haber transcurrido el plazo en que se llevó a cabo el fallido procedimiento de adquisición, el Estado peruano deberá gestionar el procedimiento de expropiación, el mismo que puede tardar meses. Y, como es de esperarse, que se haya declarado la expropiación, no implica que se los propietarios o poseedores que vivían en dicha área concesionada hayan desocupado el bien inmueble. Por tanto, probablemente también se deberá recurrir a un procedimiento de ejecución coactiva.

Tabla 3.1

Cuadro comparativo de los procedimientos de adquisición y expropiación

\begin{tabular}{|c|c|}
\hline \multicolumn{2}{|c|}{ Cuadro comparativo } \\
\hline Procedimiento de adquisición & Procedimiento de expropiación \\
\hline $\begin{array}{l}\text { - Es la primera fase de contacto con } \\
\text { el sujeto pasivo } \\
\text { - Menor tiempo de ejecución } \\
\text { Mayores incentivos para que el } \\
\text { sujeto pasivo desocupe el bien } \\
\text { inmueble } \\
\text { - Menor costo en trámites } \\
\text { administrativos } \\
\text { Menor probabilidad de recurrir a } \\
\text { un procedimiento de ejecución } \\
\text { coactiva. } \\
\text { Genera confianza en la población } \\
\text { afectada por las adquisiciones; y, } \\
\text { por tanto, } \\
\text { Menor probabilidad de rechazo } \\
\text { futuro del proyecto de } \\
\text { infraestructura vial }\end{array}$ & $\begin{array}{l}\text { - } \quad \text { Es la segunda fase de contacto } \\
\text { con el sujeto pasivo } \\
\text { - } \quad \text { Mayor tiempo de ejecución } \\
\text { - Menos incentivos para que el } \\
\text { sujeto pasivo desocupe el bien } \\
\text { inmueble } \\
\text { Mayor costo en trámites } \\
\text { administrativos } \\
\text { Mayor probabilidad de recurrir a } \\
\text { un procedimiento de ejecución } \\
\text { coactiva } \\
\text { Genera desconfianza en la } \\
\text { población; y, por tanto, } \\
\text { Genera mayor probabilidad de } \\
\text { rechazo futuro del proyecto de } \\
\text { infraestructura vial }\end{array}$ \\
\hline
\end{tabular}

Fuente: D. Leg. N. ${ }^{\circ} 1192$ (2015)

Elaboración propia

Entonces, de lo analizado, podemos concluir que, el procedimiento de adquisición por trato directo es más beneficioso que el procedimiento de expropiación. Más beneficioso para la sociedad, porque podrá negociar y recibir un pago justo por entregar la propiedad o posesión de sus inmuebles; y, para el Estado peruano, porque logrará obtener la titularidad de los predios sin tener que recurrir a su poder ius Imperium para iniciar el procedimiento de expropiación y, por tanto, ejecutar las obras viales que tanto se necesitan sin más demoras. 


\subsection{Factores de riesgo de la gestión predial en los contratos de concesión vial}

Es importante identificar los factores de riesgo de la gestión predial en los contratos viales porque nos permitirá tener un mapa claro sobre las problemáticas que enfrentamos y, de esta manera, podremos determinar las medidas preventivas que deberemos adoptar para optimizar la gestión predial.

Asimismo, utilizaremos muy frecuente los términos medida preventiva y medida correctiva, las mismas que hacen referencias a las acciones tomadas por el Estado frente a un factor de riego, según el nivel de previsibilidad.

\subsubsection{Factores de riesgo afrontadas en las adendas}

Las adendas son un mecanismo para que las partes que firman el contrato de concesión vial (el Estado y el concesionario), de común acuerdo, sea por iniciativa del Estado o del concesionario y con el visto bueno del ente regulador (OSITRAN), para que las partes modifiquen, incluyan o supriman cláusulas del contrato inicial con el fin de mejorar sus términos. (Mendiola, 2015, p. 59)

Posterior a la publicación del D. Leg. N. ${ }^{\circ} 1192$, se suscribieron seis adendas a determinados contratos de concesión vial, vinculadas al procedimiento de obtención de titularidad de las áreas concesionadas. Sin embargo, las mejoras más relevantes fueron introducidas por las adendas: A. La Adenda $\mathrm{N}^{\circ} 1$ del contrato de concesión vial Quilca y B. la Adenda $\mathrm{N}^{\circ} 2$ del contrato de concesión vial Autopista del Sol. Entonces, con el objetivo de identificar los factores de riesgos considerados en las adendas, procederemos a analizar cada uno de los contratos y adendas mencionadas. 
A. La Adenda $\mathrm{N}^{\circ} 1$ del contrato de concesión vial Quilca

El contrato de concesión vial Quilca fue suscrito el 30 de enero de 2013, bajo la modalidad Autosostenible ${ }^{13}$ y esquema de contrato BOT ${ }^{14}$. Este contrato tiene vigencia por 25 años, donde el concedente es el Estado y el concesionario es COVINCA S.A. La infraestructura concesionada tiene una extensión de 428,613 $\mathrm{Km}$, los cuales se encuentran sub divididos en cuatro tramos: 1) Dv. Quilca - Dv. Arequipa (121,549 Km), 2) Dv. Matarani - Dv. Moquegua (158,234 Km), 3) Dv. Ilo- Tacna $(113,310 \mathrm{Km})$ y 4) Tacna - La Concordia $(35,520 \mathrm{Km})$.

Tal y como señalamos en el Capítulo anterior, el contrato de concesión Quilca, al igual que en todos los contratos de concesión vial suscritos, es el concedente el responsable de realizar la gestión predial y entregar las áreas liberadas al concesionario. Asimismo, en dicho contrato se estableció que el concedente entregaría al concesionario progresivamente las áreas concesionadas según plazos pre establecidos.

De acuerdo con los plazos previstos en dicho contrato de concesión, la ejecución de las obras obligatorias debió haber iniciado el 23 de agosto de 2014, y haber culminado en agosto de 2017. Sin embargo, el inicio de la ejecución del proyecto estaba supeditado, entre otras condiciones, a la entrega de las áreas de terreno por parte del concedente; y, éste, "no cumplió con la entrega de los terrenos debido a la presencia de poblaciones asentadas que no estaban de acuerdo con el desarrollo del proyecto" (Gerencia de Regulación y Estudios Económicos de OSITRAN, 2018, párr. 42). Esta situación requirió que se hicieran modificaciones al contrato, respecto al trazo original del proyecto $\mathrm{y}$, por tanto, se suspendió la obligación de inicio de obras.

\footnotetext{
${ }^{13}$ El Decreto Legislativo N. ${ }^{\circ} 1012$ (2008) definía a la concesión autosostenible como aquella que cumpla con las siguientes condiciones: i. Demanda mínima o nula garantía financiera por parte del Estado, conforme se establezca en el Reglamento del presente Decreto Legislativo; y, ii. Las garantías no financieras tengan una probabilidad nula o mínima de demandar el uso de recursos públicos, conforme se establezca en el Reglamento del presente Decreto Legislativo. (artículo 4)

${ }^{14}$ Un proyecto BOT, por sus iniciales en inglés, consiste en la Construcción, Operación y Traspaso de una determinada obra de infraestructura al Estado, al término del contrato de concesión (World Bank Group, 2016, párr.3).
} 
Es recién en el 2015 que, el concedente aprobó los Estudios Definitivos de Ingeniería y de Impacto Ambiental de las obras elaboradas por el concesionario; así como, hizo la entrega parcial correspondiente a los terrenos del Sub tramo 03 y del Sub tramo 4. El 18 de setiembre de 2015, el concedente entregó al concesionario los terrenos correspondientes al Sub tramo 01 y del Sub tramo 02. No obstante, a diciembre de 2017, el concedente no logró cumplir con entregar la totalidad de las áreas comprometidas en concesión para el inicio de las obras.

El inicio de obras en los tramos que ya habían sido entregados fue materia de negociación en la primera adenda al contrato de concesión, suscrita el 09 de mayo de 2016. Por la Adenda $N^{\circ} 1$ del contrato de concesión vial Quilca; por un lado, se propuso (1) una nueva fecha de entrega de las áreas concesionadas por parte del concedente al concesionario, teniendo como principal objetivo que se logre entregar la totalidad de las áreas de terreno necesarias para la ejecución de la totalidad de las obras y, que permita al concesionario dar inicio a la ejecución de las obras. Sin embargo, en la adenda se precisa que, si se produce un atraso, y tal atraso no permite al concesionario iniciar o continuar con las obras en los plazos previstos, el concedente debería otorgar al concesionario una ampliación en el plazo de ejecución de obras. Por otro lado, en la adenda también se conviene que: (2) el concesionario, previo acuerdo con el concedente, podría efectuar la liberación de las áreas necesarias para el inicio o continuación de la ejecución de las obras; y, para ello, el concedente debería aprobar el presupuesto que proponga el concesionario, para la elaboración de los expedientes individuales (técnico legal) de los predios afectados por el Derecho de Vía, los mismos que deberán seguir los criterios y requisitos establecidos por la Dirección Nacional de Construcción del Ministerio de Vivienda, Construcción y Saneamiento. (3) Así mismo, los gastos en que incurra el concesionario por la ejecución de dichas actividades serán aprobadas y pagados por el concedente.

Según lo señalado en el párrafo 42 del Informe de Desempeño 2017 del contrato de concesión vial Quilca, esta modificación viabilizó el inicio de las obras de puesta a punto, el cual se produjo el 27 de mayo de 2016 (es decir, casi 21 meses después de lo previsto). De este modo a diciembre de 2017, el OSITRAN reconoció un total de USD 17,83 millones en inversiones, siendo el 
acumulado al 2017 un total de USD 22,13 millones lo que representa un avance de 16,5\% respecto del total de compromiso de inversión. (Gerencia de Regulación y Estudios Económicos de OSITRAN, 2018)

\section{B. La Adenda $\mathrm{N}^{\circ} 2$ del contrato de concesión vial Autopista Del Sol}

El contrato de concesión vial Autopista del Sol fue suscrito el 25 de agosto de 2009, bajo la modalidad Autosostenible y esquema de contrato BOT. Este contrato tiene vigencia por 25 años, donde el concedente es el Estado y el concesionario es CONVISOL S.A. La infraestructura concesionada tiene una extensión de 474,99 km aproximadamente, los cuales se encuentran subdivididos en tres sub tramos: 1) Trujillo - Chiclayo (242,61 km), 2) Chiclayo - Piura (204,58 km) y 3) Piura - Sullana (27,80 km).

$\mathrm{Al}$ igual que el anterior contrato estudiado, el concedente es el responsable de realizar la gestión predial y entregar las áreas concesionadas liberadas al concesionado. Asimismo, en dicho contrato se establecieron plazos por los que el concedente debía realizar la entrega de las áreas concesionadas progresivamente.

De acuerdo con los plazos previstos en dicho contrato de concesión, la ejecución de las obras debió haber iniciado a los 30 días calendario de acreditarse el cierre financiero (que se produjo el 31 de enero de 2011), es decir, el 02 de marzo de 2011.

El plazo establecido en el contrato, para la ejecución de las obras (construcción de la segunda calzada y obras complementarias), fue de 48 meses. Así, considerando que las obras empezarían el 02 de marzo de 2011, se tenía prevista la culminación de las mismas el 02 de marzo de 2015. No obstante, al cierre de 2015, solo se había alcanzado un avance de 27,6\% en el compromiso de inversión.

De acuerdo con el Informe de Desempeño 2017 (2018) de la concesión Autopista del Sol: Tamo Vial Trujillo - Sullana, los retrasos en la ejecución de las inversiones y de la puesta en servicio de la nueva infraestructura, se debe fundamentalmente al retraso en la entrega de predios. Como consecuencia de estas demoras, entre otros, se suscribieron dos adendas. La primera adenda al contrato 
de concesión fue suscrita el 08 de enero de 2016, la misma que tenía por objetivo incrementar el porcentaje de las Obras Adicionales previstas. La segunda adenda al contrato de concesión fue suscrita el 23 de diciembre de 2016, con el fin de viabilizar la continuación de las obras; así como, modificar el régimen tarifario de la concesión. En ese sentido, (1) se modificó la fecha de entrega de áreas concesionadas por parte del concedente al concesionario; y, por tanto, se modificó la fecha de inicio de obras. (2) Se permitió que el concesionario, a solicitud del concedente, pueda efectuar los pagos a los beneficiarios de los terrenos a liberar con compromiso de posterior pago por parte del concedente. (3) Se autorizó que, tanto el concesionario como el concedente, puedan solicitar modificaciones a los Estudios Definitivos de Ingeniería. Así como, (4) se permitió que el concesionario solicite la aceptación de las obras por sub Tramos en ciertos sectores. (Gerencia de Regulación y Estudios Económicos de OSITRAN, 2018/2, párr.7)

Pese a los cambios realizados en los contratos, hasta diciembre de 2017, el concedente entregó ' $49,3 \%$ de los terrenos para la ejecución de obras obligatorias. En vista de ello, el concesionario se vio obligado a diferir las inversiones previstas en el Programa de Ejecución de Obra, y solo ha podido avanzar con la construcción de la segunda calzada en los tramos disponibles.' (Gerencia de Regulación y Estudios Económicos de OSITRAN, 2018/2, párr.7)

En síntesis, los principales factores de riesgo que influyeron en las demoras de la gestión predial de los contratos estudiados, fueron:

- Que las partes del contrato de concesión realizaron una reducida estimación de plazos para lograr la gestión predial.

- Las poblaciones afectadas no estaban de acuerdo con el desarrollo del proyecto.

- Problemas para identificar los predios afectados por la concesión; y,

- Por tanto, problemas para identificar a los sujetos pasivos afectados por el Derecho de Vía.

- Problemas para elaborar los expedientes técnico legal de los predios afectados por el Derecho de Vía.

- Problemas de fluidez económica para realizar los pagos compensatorios a los sujetos pasivos de la gestión predial. 
Las medidas que se tomaron, mediante la suscripción de adendas, para afrontar dichos factores de riesgo fueron los siguientes:

- Al encontrarse el concedente fuera del plazo acordado para la entrega de las áreas concesionadas en ambos contratos, se modificó y se propuso una nueva fecha de entrega de dichas áreas concesionadas. Así como, se pactó que, si se vuelve a producir un atraso en la entrega de las áreas concesionadas, el concedente deberá otorgar a los concesionarios una ampliación en el plazo para la ejecución de obras.

- Como consecuencia del rechazo de las poblaciones al proyecto, se suspendió la obligación del concesionario de iniciar obras, y se hicieron modificaciones al contrato respecto al trazo original del proyecto de infraestructura.

- Se propuso que el concesionario, previo acuerdo con el concedente, podría identificar y elaborar los expedientes técnico legal de los predios afectados por el Derecho de Vía; y que, los costos que esto generase serían asumidos por el concedente.

- Se permitió que el concesionario pueda efectuar los pagos compensatorios a los sujetos pasivos de la gestión predial, a solicitud del concedente y con compromiso de pago por parte de este último.

\subsubsection{Factores de riesgo según entrevista a expertos}

En la presente sección, nuestro objetivo es identificar, desde la perspectiva de distintos especialistas en el procedimiento para obtener la titularidad de predios, los principales factores de riesgo que influyen en las demoras para ejecutar el mencionado procedimiento.

En la Tabla 3.2 se presenta la lista de los especialistas entrevistados para esta investigación, sus cargos y la entidad en la cual trabajan. 
Tabla 3.2

Listado de especialistas entrevistados

\begin{tabular}{|c|c|c|c|}
\hline Especialista & Cargo & $\begin{array}{l}\text { Entidad en la cual } \\
\text { trabajan }\end{array}$ & $\begin{array}{l}\text { Fecha de } \\
\text { entrevista }\end{array}$ \\
\hline Richard Martin Tirado & Socio fundador & $\begin{array}{l}\text { Estudio Jurídico Richard } \\
\text { Martin y Asociados }\end{array}$ & 11 de abril de 2018 \\
\hline $\begin{array}{l}\text { Guillermo García } \\
\text { Montufar Sarmiento }\end{array}$ & Socio fundador & $\begin{array}{l}\text { Estudio De la Flor, } \\
\text { García Montufar Arata \& } \\
\text { Asociados Abogados }\end{array}$ & 04 de abril de 2018 \\
\hline Juan Pacheco & $\begin{array}{l}\text { Gerente } \\
\text { General }\end{array}$ & $\begin{array}{l}\text { Asociación para el } \\
\text { Fomento de la Inversión }\end{array}$ & $\begin{array}{l}28 \text { de marzo de } \\
2018\end{array}$ \\
\hline Raúl Ravina & Socio & Estudio Grau & $\begin{array}{l}07 \text { de mayo de } \\
2018\end{array}$ \\
\hline Franco Soria & Socio & Estudio Grau & $\begin{array}{l}22 \text { de mayo de } \\
2018\end{array}$ \\
\hline
\end{tabular}

Elaboración propia

Richard Martin Tirado, Socio fundador del Estudio Jurídico Richard Martin y Asociados, considera que la elaboración del expediente técnico legal es la fase del proceso de obtención de áreas concesionadas que demanda más tiempo en ejecutar. Si bien el objetivo final es solicitar la tasación, esta toma demasiado tiempo en prepararse. Así también, considera que la valorización, producto de las tasaciones, es un factor crítico en el proceso de obtención de áreas concesionadas. La gente no suele estar de acuerdo con los valores que se les asigna a los inmuebles y, por tanto, impugnan esperando incrementar dicha valorización. (R. Martin, comunicación personal, 11 de abril de 2018)

Para Guillermo García-Montufar Sarmiento, Socio fundador del Estudio De la Flor, García-Montufar Arata \& Asociados Abogados, la tasación es el punto más crítico del proceso de obtención de áreas concesionadas. Las tasaciones, a cargo del MVCS, demoran en ejecutarse y muchas veces hay oposiciones de parte del propietario por la valorización del inmueble. Así también, considera que debería reforzarse el poder de negociación de la valorización del bien inmueble entre en el inversionista privado y el sujeto pasivo en el proceso de adquisición por trato directo. Además, Guillermo García Montufar considera que, la opción que permite que los procesos de adquisición de inmuebles puedan estar a cargo del privado, ha impactado positivamente en el proceso de obtención de áreas concesionadas. Considera que el privado es eficiente y le toma 
menos tiempo en ejecutar las adquisiciones que al Estado peruano. (G. García, comunicación personal, 04 de abril de 2018)

De acuerdo con Juan Pacheco, Gerente General de AFIN, la principal problemática en el proceso de obtención de áreas concesionadas es la modalidad con la que se afronta. (J. Pacheco, comunicación personal, 28 de marzo de 2018)

Él propone que la obtención de áreas debe iniciar con la elaboración de un Plan de Compensación y Reasentamiento Involuntario - PACRI, el mismo que debe culminar con la adquisición por trato directo de los predios requeridos en la concesión. En ese sentido, pone como ejemplo la concesión público-privada de infraestructura vial de la Vía Expresa Línea Amarilla, que fue otorgada por la Municipalidad de Lima en el año 2009. En este proyecto el concesionario ejecutó el Programa de reubicación de viviendas, por el que 1300 familias fueron reubicadas a una parte del Distrito del Rímac y otras compensadas. Juan Pacheco afirma que se logró la obtención de dichas áreas concesionadas sin realizar expropiación alguna (Un verdadero logro). Así mismo, precisó que la elaboración de un PACRI es una tendencia de uso a nivel internacional y que, a corto plazo, será necesario su implementación para la ejecución de proyectos infraestructura. (J. Pacheco, comunicación personal, 28 de marzo de 2018)

Otra problemática que Juan Pacheco ha identificado es que, el D. Leg. N. ${ }^{\circ} 192$ y el Decreto Legislativo $N^{\circ} 1224(2015)^{15}$, tienen pendiente considerar en su legislación los estudios ambientales (Certificación Ambiental ${ }^{16}$ ). Pone por ejemplo el numeral 16.4, artículo 16 del D. Leg. N. ${ }^{\circ} 1192$, por el que se prescribe la posibilidad iniciar con las gestiones para la adquisición de los inmuebles con la declaratoria de viabilidad; sin considerar que, si no se cuenta con la Certificación Ambiental, no se puede realizar las adquisiciones; y que, la Certificación Ambiental aún podrá obtenerse cuando se hayan culminado los Estudios de Ingeniería Definitivos del Proyecto vial; el mismo que se realiza (comúnmente) en meses posteriores a la fecha de suscripción del contrato de concesión vial. (J. Pacheco, comunicación personal, 28 de marzo de 2018)

\footnotetext{
${ }^{15}$ Norma derogada por el D. Leg. $N^{\circ} 1362$, vigente desde el 24 de julio de 2018.

${ }^{16}$ La Dirección General de Asuntos Socio Ambientales se encarga de velar por el cumplimiento de las normas socio-ambientales, con el fin de asegurar la viabilidad socio ambiental de los proyectos de infraestructura y servicios de transporte. Entre sus funciones se encuentra la Certificación Ambiental de proyectos de infraestructura de transportes (carreteras, puentes, ferrovías, aeropuertos y puertos) y servicios.
} 
Según Raúl Ravina, Socio del Estudio Grau, la identificación de los sujetos pasivos y la tasación de los predios son las principales razones por las que el proceso de obtención de áreas concesionadas toma demasiado tiempo en ejecutarse. Respecto a la demora en la identificación de los sujetos pasivos, nos dice que esta problemática se origina en el deficiente sistema de búsqueda catastral, pues este sistema está diseñado para la búsqueda individual de predios. Por tanto, cuando se desee identificar a los titulares registrales de 1000 predios; deberá realizarse la búsqueda catastral individual de cada uno de estos. Sumado a ello, precisa que el sistema de búsqueda registral no es fiable, pues SUNARP no genera catastro, sino es quien recibe y ordena la información de los entes generadores, la misma que a veces resulta ser contradictoria. Todo ello, dificulta identificar al verdadero sujeto pasivo del proceso de obtención de áreas concesionadas. Respecto a la tasación de predios, Raúl Ravina considera perjudicial que esta fase se encuentre bajo responsabilidad del MVCS, debido a que se forma un cuello de botella. Primero, las tasaciones se realizan de forma individual por cada predio. Segundo, el MVCS no solo realiza la tasación individual de los predios concesionados para proyectos de infraestructura vial, sino también de muchos otros proyectos de infraestructura. (R. Ravina, comunicación personal, 07 de mayo de 2018)

En ese sentido, Franco Soria, Socio del Estudio Grau, también considera que la principal problemática en el proceso de obtención de áreas concesionadas está en identificar al sujeto pasivo. No solo a partir de la búsqueda registral, sino, desde la definición del sujeto pasivo en el marco legal. Según el D. Leg. N. ${ }^{\circ}$ 1192, el sujeto pasivo podría: ser el propietario inscrito, el propietario no inscrito en Registros Públicos cuya propiedad se acredita con documento de fecha cierta y que tiene tracto, poseedor de más de diez años sobre bienes de dominio privado del Estado, poseedor de más de diez años sobre áreas sin inscripción registral, junta de propietarios en caso de propiedad exclusiva y común, y el titular de dominio fiduciario y el titular registral en caso de patrimonio fideicometido. Por tanto, lograr identificar al sujeto pasivo en la práctica es un proceso riguroso que puede alargar indefinidamente el inicio del trato directo. (F. Soria, comunicación personal, 22 de mayo de 2018)

De acuerdo con Franco Soria, otro factor, que puede demorar el inicio del proceso de obtención de áreas concesionadas, es la elaboración del expediente técnico legal; pues, aunque se cuente con un derecho de propiedad exclusivo y oponible, muchas veces hay 
una problemática predial-registral. Hay predios inscritos sin planos o con croquis; predios en duplicidad registral; predios con planos inscritos, cuya ocupación en realidad difiere de información registral; insuficiente información catastral - registral; predios que han sido inscritos con coordenadas; o, diferente geo-referenciación (Sistemas PSAD 56/WGS 84). Todo lo anteriormente descrito dificulta la labor del sujeto activo para elaborar los expedientes técnicos individuales.

\subsection{Asignación de los factores de riesgo de la gestión predial}

En esta sección analizaremos los factores de riesgo de la gestión predial, según los casos estudiados y la opinión de los expertos.

\subsubsection{Análisis a partir de los contratos de concesión vial}

La demora para obtener la titularidad de los predios afectados por el Derecho de Vía, es una problemática común en todos los contratos de concesión vial. Para identificar los principales factores de riesgo, hemos estudiados los contratos de concesión vial Quilca y Autopista del Sol; así como, hemos resaltado las medidas tomadas por el concedente y concesionario, por medio de las adendas que dichas partes suscribieron; las mismas que analizaremos y comentaremos en la presente sección.

A. Cuando el concedente no cumplió con entregar los predios afectados por el Derecho de Vía, dentro de los plazos convenidos, éste incurrió en incumplimiento contractual. Esta problemática fue afrontada ampliando el plazo de entrega de las áreas concesionadas; así como, ampliando el plazo de ejecución de obras.

Consideramos que la ampliación del plazo de entrega de las áreas concesionadas no brinda solución al problema, sino brinda un tiempo adicional al concedente para seguir con la gestión predial. Sin embargo, es la gestión predial la que tiene trabas; y, mientras no se afronten directamente, se volverá a incurrir en incumplimiento contractual. Una forma de prevenir este factor de riesgo es establecer plazos prudentes en los contratos de concesión vial; así como ampliar los plazos en el D. Leg. N. ${ }^{\circ} 1192$. 
En ese sentido, la ampliación del plazo de ejecución de obras era necesario, pues, como mencionamos anteriormente, no se pueden iniciar la fase de ejecución de las obras mientras que el Concesionario no cuente con las áreas concesionadas. Sin embargo, la ampliación de plazos debe ser una medida excepcional.

B. Otro factor de riesgo fue el rechazo al proyecto por parte de la población afectada, y la medida que se tomó fue modificar el trazo original del proyecto de infraestructura.

Modificar el trazo original del proyecto de infraestructura es una medida correctiva, frente al factor de riesgo de rechazo al proyecto. Sin embargo, consideramos que esta medida debería ser excepcional, y no la regla general; pues, genera demoras (más de un año en el contrato de concesión vial Quilca) al realizarse los nuevos estudios, y sobrecostos que son asumidos por el concedente.

Para evitar las demoras que este factor de riesgo pudiese ocasionar, la delimitación del trazo del proyecto debería realizarse teniendo en cuenta la opinión de la población afectada; para que así se promueva el sentido de pertenencia del proyecto por parte de la población. Según lo señalado por Juan Pacheco, y lo investigado, proyectos de infraestructura vial (a nivel municipal) elaboraron y aplicaron Planes de Compensación y Reasentamiento Involuntario para Proyectos de Infraestructura de Transporte, y su impacto social fue positivo.

C. Con relación al factor de riesgo originado por los problemas para identificar y elaborar los expedientes técnico legal de los predios afectados por el Derecho de Vía, se afrontó trasladando la responsabilidad de ejecución al concesionario. Según lo estudiado, estos cambios en las adendas han permitido liberar más áreas concesionadas; y, por tanto, avanzar con la ejecución de obras de infraestructura que se encontraban paralizadas por las demoras.

Consideramos que esta medida sí afrontó el factor de riesgo identificado, pues colaboró directamente a acelerar la gestión predial. Las demoras en la identificación y elaboración de los expedientes técnico legal de predios afectados 
se deben principalmente a la carga administrativa que tiene Provias Nacional para realizar dichas labores; y aunque muchas veces el concedente opta por contratar a un tercero para que lo realice, este proceso de contratación toma tiempo en planificarse. Adicionalmente, el concedente debe realizar muchos trámites burocráticos que ralentizan dichas fases del procedimiento. Así también, consideramos adecuado que los costos de la identificación y elaboración de los expedientes técnico legal de los predios sean asumidos y realizados por el concedente, toda vez que, a la fecha de suscripción del contrato, se acordó que dichos costos serían asumidos por el concedente.

D. En ambos contratos de concesión vial se identificó que la demora en los pagos es un factor de riesgo común.

Generalmente, las demoras en realizar el pago se deben a dos factores: Falta de liquidez económica y problemas de fluidez económica. El primero surge cuando el concedente no tiene el dinero requerido; el segundo surge cuando, pese a tener el dinero, no puede disponer libremente del mismo. Ante este factor, la medida adoptada fue pedir al concesionario que efectúe los pagos compensatorios a los sujetos pasivos de la adquisición y/o expropiación, con compromiso de devolución posterior del concedente al concesionario.

El concesionario, a diferencia del concedente, dispone de liquidez; así como, no tiene que seguir un trámite burocrático y riguroso para realizar los pagos compensatorios a los sujetos pasivos. Entonces, la medida tomada es óptima ante las demoras en efectuar los pagos a los sujetos pasivos.

Consideramos que esta medida pudo haberse adoptado desde el inicio de la concesión vial como una medida preventiva y, de esta manera, se hubiese permitido al concesionario planificar sus costos de operación. En consecuencia, la gestión predial se habría realizado de forma óptima.

Entonces, de acuerdo a lo analizado, los factores de riesgo identificados pudieron ser previsibles inclusive antes de la suscripción de los contratos de concesión vial. Por tanto, las medidas correctivas tomadas para afrontar las demoras en el proceso de obtener 
la titularidad de las áreas concesionadas, pueden ser adoptadas como medidas preventivas.

\subsubsection{Análisis a partir de entrevistas a expertos}

Para llevar a cabo el presente análisis, se consideró las respuestas de los expertos entrevistados, a quienes se les consultó, en base a su experiencia, ¿Cuáles consideran son las fases, del procedimiento de obtención de áreas concesionadas, que toman más tiempo en ejecutarse? Los especialistas señalaron que los factores de riesgo que generan más demoras en el procedimiento de obtención de áreas concesionadas son: (i) La identificación de los bienes inmuebles, (ii) la identificación del sujeto pasivo, (iii) la elaboración del expediente técnico, (iv) el tiempo que toma en realizarse las valorizaciones de los bienes inmuebles, y (v) el valor compensatorio que resulta de la tasación.

A partir de las entrevistas realizadas, hemos identificado tres nuevos factores de riesgo: Demora en la identificación de los bienes inmuebles, demora en el tiempo que toma en realizarse las valorizaciones de los bienes inmuebles, y el valor compensatorio que resulta de la tasación. Dichos factores de riesgo no fueron considerados en los contratos de concesión vial estudiados, ni han sido afrontados con medidas correctivas en las adendas suscritas. Sin embargo, los factores de riesgos identificados por los expertos sí podrían repercutir en el tiempo que toma realizar la gestión predial, si no se adoptan las medidas preventivas adecuadas.

A. Demora en la identificación de bienes inmuebles

La etapa de identificación de bienes inmuebles se convierte en un factor de riesgo por los problemas que existen para identificar registralmente los mismos porque la mayoría de estos bienes inmuebles existentes no se encuentren inscritos en Registros Públicos, o si se encuentran inscritos, las coordenadas no coinciden con la realidad, entre otros; además que, debe realizarse la búsqueda individual de cada bien inmueble.

Adicionalmente, en la práctica, la identificación de los bienes inmuebles solo se puede realizar después a la elaboración de los Estudios Definitivos de 
Ingeniería, el mismo que generalmente se concluye meses después de la suscripción del contrato de concesión vial.

Entonces, para poder prevenir las demoras en la identificación de inmuebles, en primer lugar, se debe optar por cambiar el plazo de elaboración de los Estudios Definitivos de Ingeniería, y establecer que sean entregados antes de la suscripción del contrato de concesión vial; y, en segundo lugar, se debe modificar y mejorar el marco legal registral inmobiliario; así como, el sistema empleado para identificar bienes inmuebles.

B. Demora en el tiempo que toma en realizarse las valorizaciones de los bienes inmuebles

Este factor de riesgo está bajo responsabilidad del Estado, representado por el MVCS a la fecha de hoy.

La responsabilidad de realizar las tasaciones ha variado en muy cortos periodos de tiempo. Hasta el 16 de noviembre de 2014, el Ministerio de Vivienda, Construcción y Saneamiento (MVCS) era el responsable de realizar las tasaciones. Luego, esta responsabilidad se trasladó a la Dirección General de Concesiones en Transportes del MTC, hasta que el 06 de enero de 2017, el Decreto Legislativo N. ${ }^{\circ} 1330$ (2017) determinó que sería nuevamente el MVCS quien fije el valor de las tasaciones. Es decir, la demora en realizar las valorizaciones de los bienes inmuebles ha sido afrontada rotando la responsabilidad entre distintas entidades estatales, sin lograr buenos resultados, pues las demoras en ejecutar las tasaciones persisten. Entonces, este factor de riesgo debe afrontarse de manera distinta.

El tiempo que toma en realizarse debe ser prudente, pues si toma más tiempo que el estimado, podría influenciar negativamente en el sujeto pasivo, generando expectativas sobre la valorización final; así como, retrasar las demás etapas de la gestión predial. 
C. El valor compensatorio que resulta de la tasación

La tasación es la etapa más importante del procedimiento de adquisición; pues, el resultado de la valorización influye en la decisión de entrega del inmueble del sujeto pasivo al sujeto activo.

Lo sujetos pasivos suelen estar disconformes con el valor compensatorio determinado en la tasación por el MVCS. Los sujetos pasivos señalan que es poco el valor asignado al bien inmueble y, por tanto, se niegan a aceptar el trato directo, debiéndose recurrir al procedimiento de expropiación para lograr obtener la titularidad de dichas áreas.

Es inevitable que los sujetos pasivos no reclamen una indemnización mayor, por ello, se deben brindar facilidades que les permitan reclamar una indemnización mayor, ya sea por la vía judicial o la vía arbitral, y a la par, seguir con el procedimiento de adquisición.

\subsection{Nueva asignación de los factores de riesgo de la gestión predial}

A octubre de 2018, ProInversión tiene a cargo dos proyectos de infraestructura vial. Se encuentra convocado el proyecto Longitudinal de la Sierra Tramo 4: HuancayoIzcuchaca-Mayocc-Ayacucho/Ayacucho-Andahuaylas-Puente Sahuinto/ Dv. Pisco Huaytará - Ayacucho (en adelante, Longitudinal de la Sierra Tramo 4). Mientras que, el proyecto Longitudinal de la Sierra Tramo 5 se encuentra por convocar y, por tanto, no han publicado un proyecto de contrato.

El proyecto Longitudinal de la Sierra Tramo 4 se constituirá bajo la modalidad cofinanciada $^{17}$, con una duración no menor de 25 años; donde el concedente será el Estado y el concesionario será una empresa privada. La infraestructura ha concesionarse tendrá una extensión de 970 km aproximadamente, y estará subdividida en 18 sub tramos; mientras que la adjudicación está prevista para el primer semestre de 2019. (Agencia de Promoción de la Inversión Privada, s.f.)

${ }^{17}$ El núm. 1 del art. 22 del D. Leg. N. 1362 define a las Asociaciones Público Privadas Cofinanciadas como aquellas que requieren cofinanciamiento, u otorgamiento o contratación de garantías financieras o garantías no financieras que tienen probabilidad significativa de demandar cofinanciamiento. 
ProInversión ha publicado la versión final del contrato Longitudinal de la Sierra Tramo 4 en su página web oficial y ha incorporado modificaciones significativas en el Capítulo V, sobre el 'Régimen de bienes'. Por ello, en la presente sección nuestro objetivo será identificar los factores de riesgos que han sido considerados en el contrato y determinar cómo serán afrontados.

A continuación, mencionaremos los factores de riesgo que han sido considerados en el diseño del contrato Longitudinal de la Sierra Tramo 4:

a) La gestión predial está a cargo del concedente; sin embargo, la identificación de los bienes inmuebles, la identificación del sujeto pasivo y la elaboración del expediente técnico legal del Sub Tramo Izcuchaca - Mayocc (cuya longitud es de $116.86 \mathrm{~km}$., aproximadamente), será ejecutada por el concesionario de acuerdo a los términos del contrato de concesión. Los costos que generen dicha labor serán pre aprobadas y pagadas, posterior a su ejecución, por el concedente.

b) La identificación de los bienes inmuebles, sujeto pasivo y elaboración de los expedientes técnicos de los demás Sub tramos, serán ejecutados por cuenta y riesgo del concedente.

c) La identificación de los bienes inmuebles afectados por el Derecho de Vía se iniciará posteriormente a la fecha de suscripción del contrato de concesión.

d) Respecto a las demoras para gestionar el trato directo, con relación al Sub Tramo Izcuchaca - Mayocc, el concesionario podrá realizar las acciones necesarias para contar con la libre disponibilidad de las áreas concesionadas. (Agencia de Promoción de la Inversión Privada, s.f.)

Algunos aspectos relevantes que también se consideraron en el contrato Longitudinal de la Sierra Tramo 4, que no se consideraron en los anteriores contratos de concesión vial, son:

a) Los plazos convenidos para la entrega de las áreas concesionadas oscilan desde los 30 días calendario hasta los 5 años, contados a partir de la fecha de suscripción del contrato de concesión.

b) Se permite modificar las condiciones de plazo para la ejecución de la Rehabilitación y Mejoramiento, si: (a) no se produce la entrega de las áreas de 
terreno liberadas determinadas en el Estudios Definitivos de Ingeniería, y si (b) tal atraso no permite al concesionario iniciar o continuar con la rehabilitación y mejoramiento.

c) Previa conformidad y aprobación por parte del concedente de los expedientes correspondientes, el concesionario podrá, realizar las acciones necesarias para contar con la libre disponibilidad de las áreas. Los gastos en que incurra el concesionario por la ejecución de dichas actividades serán aprobados y pagados por el concedente.

d) Durante el acto de toma de posesión, el concedente y el concesionario suscribirán las correspondientes actas de Entrega Parcial de Bienes, las cuales formarán parte del Acta Integral de Entrega de Bienes. En las respectivas Actas de Entrega Parcial de Bienes se establecerán las condiciones generales de su entrega.

e) Los 18 sub tramos del proyecto Tramo 4 serán entregados por el concedente al concesionario, con los Derechos de Vía aprobados por Resolución Ministerial.

f) Finalmente, el concedente será el encargado de realizar el saneamiento físico legal ${ }^{18}$ de los bienes a ser entregados en concesión. El Apéndice 8 del Anexo 1 del contrato de concesión establece los lineamientos por los que el concesionario contratará a un Consultor (externo o interno) con la finalidad de que éste lleve a cabo el proceso de saneamiento y/o inscripción registral de las áreas afectadas por la obra vial.

g) Finalmente, se establece cuánto pagará el concedente al concesionario por los informes que éste último genere. Así también, está previsto que toda información recabada será puesta a disposición del Provias Nacional. (Agencia de Promoción de la Inversión Privada, s.f.)

${ }^{18}$ Como ya mencionamos, el saneamiento físico legal se realiza cuando el bien inmueble, requerido por el contrato de concesión, se encuentra en titularidad del Beneficiario; es decir, es un procedimiento posterior a los procedimientos de adquisición y expropiación. 


\subsubsection{Análisis a partir de los factores de riesgo considerados en los proyectos en cartera}

Nuestro siguiente análisis es sobre los factores de riesgo considerados en el proyecto del contrato de concesión Longitudinal de la Sierra Tramo 4. De acuerdo a lo estudiado, la gestión predial sigue estando bajo responsabilidad del concedente, al igual que en los contratos de concesión vial vigentes; sin embargo, han variado distintos aspectos de los procedimientos de adquisición y expropiación, en comparación con el tradicional contrato de concesión.

A. Con relación al riesgo de incumplir los plazos de entrega de las áreas concesionadas, se han ampliado considerablemente los plazos para realizar el procedimiento de adquisición por trato directo $\mathrm{y}$, de corresponder, el procedimiento de expropiación, con el objetivo de no incumplir los contratos de concesión que anteriormente prescribían en un corto periodo de tiempo. Sin embargo, esta medida no es la solución al problema, pues solo se está extendiendo el plazo de entrega; $y$, sin medidas que impulsen el procedimiento de adquisición y/o expropiación no se logrará obtener la titularidad de las áreas concesionadas. Por ello, esta cláusula es importante porque establece adecuados plazos de entrega, por lo que evitamos incumplir el contrato; pero, como mencionamos anteriormente, sin otras medidas que impulsen el procedimiento para obtener la titularidad, esta cláusula no serviría de nada.

B. Resalta más aún que, desde el inicio del contrato, el concesionario podría, por su propia cuenta o sub contratando a una empresa, formular el diagnostico técnico legal, el plan de saneamiento físico legal y elaborar los expedientes técnico legal de los predios afectados por el Derecho de Vía del sub tramo Izcuchaca-Mayocc, con cargo a que, posteriormente, el concedente le devuelva al concesionario los gastos generados. Este sub tramo es importante porque tiene más posibilidades de requerir que se ejecute procedimientos para obtener la titularidad de las áreas privadas que ocupan el Derecho de Vía. Sin embargo, considerando que el esfuerzo más importante se realizará en el sub tramo Izcuchaca - Mayocc, sería conveniente que sea responsable el concesionario de efectuar la gestión predial en los demás Sub tramos. Algunas razones son: 
- El concesionario contratará profesionales o una empresa especializada (en adelante, "contratista"), con experiencia en formular el diagnostico técnico legal, el plan de saneamiento físico legal y elaborar los expedientes técnico legal, por lo que, el concedente ahorraría tiempo y esfuerzo en realizar un nuevo proceso de licitación para encontrar a un nuevo contratista que ejecute los mismos servicios para los demás tramos.

- El contratista, contratado por el concesionario, aprenderá sobre las condiciones del proyecto y habrá una comunicación fluida entre ambos, ya sea para despejar dudas, sugerir cambios o para que el concesionario realice un seguimiento constante al contratista.

Sin embargo, en este contrato de concesión vial no se considera la elaboración de un PACRI. Según lo consultado a ProInversión (quien dirige el proceso de licitación), señala que no será necesario elaborar un PACRI, debido a que serán pocos los bienes inmuebles afectados por los procedimientos de liberación de áreas, ya que se trata de una rehabilitación de vía. Además, precisan que estos bienes inmuebles recién serán identificados con los Estudios Definitivos de Ingeniería que realizará el concesionario (contratista ganador del proceso de licitación).

Nosotros consideramos que, aunque sean pocos los sujetos pasivos afectados por la gestión predial, es igual de necesario que se realice un PACRI.

Como mencionamos anteriormente, el PACRI permite realizar los estudios de impacto social, y establecer vínculos de confianza con el concesionario; así como brinda legitimidad y aceptación respecto al proyecto que se ejecutará en la comunidad. Adicionalmente, queremos recalcar que es importante que la identificación de los bienes inmuebles y sujetos pasivos (parte inicial de la elaboración de un PACRI), se realice a la par con los Estudios Definitivos de Ingeniería, pues de esta forma, evitaremos realizar modificaciones posteriores a dichos estudios, tal como sucedió en el contrato de concesión Quilca; así como, minimizaremos la posibilidad de riesgos en sobrecostos y demoras para realizar nuevos estudios.

En el contrato Longitudinal de la Sierra Tramo 4 tampoco se han considerado medidas para prevenir la falta de fluidez económica (necesarios para realizar los pagos 
compensatorios a los sujetos pasivos), pese a que se trata de un problema común en los contratos de concesión vial. Como mencionamos anteriormente, es conveniente que sea el concesionario quien realice los pagos compensatorios, toda vez que dispone de liquidez y no tiene trámites burocráticos que seguir.

\subsection{Conclusiones del Tercer Capítulo}

Respecto al análisis realizado sobre los indicadores de los factores críticos de éxito, podemos concluir que:

- Para lograr compensar de forma justa al sujeto pasivo por la pérdida de su derecho de propiedad, se debe establecer una comunicación continuada y sostenida con los sujetos pasivos, la misma que se puede lograr a través de la elaboración de los PACRI.

- Para obtener la titularidad del área concesionada en el periodo de tiempo más breve posible, se deberá procurar obtener la titularidad de los predios por medio del procedimiento de adquisición por trato directo.

Producto del análisis realizado a los contratos de concesión vial Quilca y Autopista del Sol, y de acuerdo a la opinión de expertos entrevistados, hemos identificado los factores de riesgo más relevantes de la gestión predial, los mismos que son: Convenio de plazos reducidos para realizar la gestión predial, posibilidad de rechazo social del proyecto a ejecutarse, problemas para identificar los bienes inmuebles afectados por el Derecho de Vía, problemas para identificar a los sujetos pasivos, demora para elaborar el expediente técnico legal, demora en realizar las valorizaciones de los bienes inmuebles, valor compensatorio que no está de acuerdo a los intereses del sujeto pasivo, demora en gestionar el trato directo, problema de liquidez económica para realizar pagos compensatorios, y demora en gestionar los pagos compensatorios.

Dichos factores de riesgos han sido afrontados con medidas correctivas, a través de adendas. Sin embargo, en el proyecto de contrato de concesión Longitudinal de la Sierra Tramo 4, hemos identificado que se han adoptado medidas preventivas frente a los factores de riesgos aquí hallados. 
Se han señalado las siguientes medidas preventivas para afrontar algunos de los factores de riesgo mencionados: (i) Pactar en el contrato de concesión vial plazos amplios para lograr obtener la titularidad de los predios e (ii) impulsar la gestión predial por trato directo. Con relación a uno de los sub tramos del contrato Longitudinal de la sierra Tramo 4, se pactó que el concesionario sería responsable de: (iii) identificar los bienes inmuebles, (iv) identificar a los sujetos pasivos y (v) elaborar los expedientes técnicos. Mientras que, la obtención de la titularidad de los predios ubicados en los demás tramos, junto con todos los demás factores de riesgos, serían responsabilidad del concedente.

Por lo desarrollado, concluimos que todos los factores de riesgo identificados pueden ser negociados entre las partes (concedente y concesionario) en los contratos de concesión vial, y, de esta forma, ser afrontados preventivamente; así como, la asignación de los factores de riesgo. 


\section{CAPÍTULO IV: OBTENCIÓN DE PREDIOS EN LAS AMÉRICAS}

\subsection{Infraestructura vial en América Latina}

Al igual que Perú, a inicios de los años 90 muchos países en América Latina atravesaban por una crisis en infraestructura vial.

Según Rufián (2002):

En Colombia, la inversión promedio con anterioridad a esta fecha era cercana al $0,7 \%$ del PIB, frente a una inversión estimada deseable del $2 \%$ o $3 \%$ del producto. En Chile, la red vial pavimentada se incrementó en 32\% entre 1974 y 1989, mientras que la flota de vehículos lo hizo en $150 \%$ durante el mismo período, estimándose los déficits de infraestructura vial en 4.250 millones de dólares y en 2.000 millones de dólares para vialidad interurbana y urbana, respectivamente. En Perú, a la misma fecha, sólo el 8\% del sistema vial del país estaba en buen estado, mientras que el $16 \%$ se encontraba en un estado regular y el resto en mal estado, lo que dificultaba enormemente la actividad económica del país. (p. 11)

Así también, según González (2007), es recién a partir de 1990, que el país mexicano aceleró la construcción de infraestructura de carreteras, mediante el otorgamiento de cerca de medio centenar de concesiones otorgadas para la construcción, operación, explotación y conservación del sistema vial (p. 1).

Los cuatro países iniciaron en la década de los noventa programas de mejoramiento vial, con el objetivo de estructurar una red vial que permitiera satisfacer adecuadamente las necesidades de transporte de sus ciudadanos. Para tal efecto, según Rufián (2002):

Los programas de mejoramiento vial incluyeron mecanismos concebidos para lograr la incorporación de capitales privados mediante contratos de concesión de obra pública, financiados por empresas nacionales o extranjeras que 
recuperarían su inversión a través de garantías del Estado, subsidios y peajes. Sin embargo, los resultados han sido desiguales. (p. 12)

Según el estudio anual realizado por The Economist Intelligence Unit (2017), Chile y Colombia son los países que lideran en Latinoamérica en Proyectos de Infraestructura. Mientras que Perú se encuentra ubicado en el puesto número 5 y México, en el número 6.

The Economist Intelligence Unit (2017) señala que Chile cuenta con un sólido marco normativo y de apoyo institucional para las APP, que se ve reforzado por un sólido clima de inversión y negocios y por instrumentos de financiación desarrollados. Dicho país ha implementado más de 70 proyectos de APP en los últimos cinco años, según la base de datos PPI del Banco Mundial.

Sobre Colombia, sabemos que su entorno está marcado por un sólido marco regulatorio respaldado por una nueva ley de APP implementada en el 2012. Además, las entidades de APP en el país tienen experiencia en desarrollar y mantener contratos de APP, lo que sirve para atraer la participación del sector privado en proyectos de infraestructura. Esto se evidencia en los aproximadamente 37 proyectos adjudicados al sector privado en los últimos cinco años (The Economist Intelligence Unit, 2017).

Por esta razón, analizaremos el contexto de estos países, desde los años 90 hasta la actualidad, estudiaremos las etapas por las cuales atravesaron, e identificaremos los principales puntos que mejoraron estos países en materia de obtención y liberación de áreas concesionadas.

- Chile

La historia de las licitaciones del sistema de concesiones chilena se puede agrupar fundamentalmente en cuatro generaciones. Estas generaciones dan cuenta del aprendizaje de los actores involucrados en la industria, y de la experiencia que adquirió en la medida que se consolidaron diversos criterios técnicos de los modelos de licitación y financieros.

La primera generación de contratos de concesión fue realizada sobre vías terrestres ya existentes, pero que requerían ser mejoradas o potenciadas. La segunda generación de proyectos se inició con tres licitaciones de infraestructura, que superaban 
los 100 millones de dólares. Los proyectos de esta fase fueron la Ruta 78, que une Santiago con el puerto de San Antonio; el Acceso Norte a Concepción, primera autopista concesionada con un trazado nuevo; y la Ruta Santiago-Los Andes, que conduce hasta el paso Los Libertadores, en la frontera con Argentina. Los dos primeros fueron adjudicados en 1995 y el tercero en 1996. La experiencia adquirida de estas concesiones permitió mejorar la gestión de la autoridad, no sólo en materia de mecanismos de adjudicación, sino también en ámbitos técnicos específicos, como los antecedentes de ingeniería necesarios (Camino la Madera), la fotometría (Acceso Norte a Concepción) y los procedimientos de expropiaciones (Ruta 78), entre otros. Esa experiencia adquirida se plasmó luego en la tercera generación, que agrupó el mayor número de proyectos licitados. La adjudicación de estas licitaciones tuvo lugar entre 1996 y 1998. (Coordinación de Concesiones de Obras Públicas, 2016)

En la actualidad el Estado chileno se rige por la Ley de Concesiones de Obras Públicas (Ley $\mathrm{N}^{\circ} 20410,2010$ ), por la que se establece que debe haber un mínimo de estudios necesarios para la evaluación y estructuración de los proyectos. Esta ley introdujo mejoras significativas en la legislación anterior, incluida una mayor transparencia e incorporó criterios de mayor objetividad en torno a la renegociación y la transferencia involuntaria de riesgos comerciales.

Consideramos que el éxito de las concesiones en Chile se debe a que más inversionistas fueron atraídos por los siguientes factores: Estabilidad política del país; la calidad de la información previa para los inversionistas, desde estudios de impacto ambiental hasta la ingeniería definitiva; el trato directo con los inversionistas potenciales durante la precalificación por parte de la Coordinación de Concesiones del Ministerio de Obras Públicas, que permitía la promoción de estos proyectos y presentaba su atractivo para los inversionistas; y la participación del Estado en los riesgos de los proyectos de largo plazo y el aporte estatal de altos montos (cofinanciamiento) que garantizaba la viabilidad de los proyectos (Mendiola et al., 2011). 


\section{- Colombia}

$\mathrm{Al}$ igual que Chile, Colombia ha atravesado por cuatro generaciones de concesiones. En la primera generación de contratos de concesión se apreciaron fallas en los contratos que consistían en demoras en la entrega de los predios y demoras en los plazos para la emisión de licencias ambientales, por lo que se consideraron una falla del sistema. De igual forma, parte de este problema fue que el Estado colombiano entregaba al postor concesionario el proyecto en etapa de pre factibilidad y perdía parte del control. Esto se realizó con el objetivo de que el concesionario confeccionara y se encargara del diseño definitivo del proceso de expropiación. Sin embargo, no hubo una adecuada supervisión por parte del Estado colombiano. Respecto de la asignación de riesgos, debido a que se puso mayor énfasis en el Estado, solo se benefició al concesionario en el caso del riesgo cambiario que fue asumido completamente por este último. A ello se sumó un cálculo deficiente del tráfico, lo que generó mayores problemas y afectó los flujos. En la segunda generación se buscó superar las fallas anteriores, pero se terminó cayendo en problemas similares debido fundamentalmente a fallas en el diseño de los contratos. En la tercera generación se observó un mayor grado de institucionalidad en el sector y mejoras en la distribución de riesgos y los estudios técnicos y financieros. A pesar de ello, se continuaron reclamando mejoras al sistema.

Actualmente, Colombia se encuentra atravesando por una cuarta generación de APP, que tiene nuevas exigencias técnicas, pues brindan mucha importancia a los estudios requeridos para los proyectos de infraestructura; así como, ha realizado cambios en la asignación de riesgos.

$\mathrm{Al}$ abrir los procesos de selección de contratistas para la ejecución de proyectos de APP de iniciativa pública, la entidad pública solicitante debe contar con los estudios vigentes de carácter técnico, socioeconómico, ambiental, predial, financiero y jurídico acordes con el proyecto; la descripción completa del proyecto, incluyendo diseño, construcción, operación, mantenimiento, organización o explotación del mismo; el modelo financiero detallado y formulado que fundamente el valor del proyecto; descripción detallada de las fases y duración del proyecto y justificación del plazo del contrato. Además, debe contar con los estudios financieros sobre la evaluación costo beneficio del proyecto analizando su impacto social, económico y ambiental sobre la 
población directamente afectada, evaluando los beneficios socioeconómicos esperados; entre otros requisitos establecidos en el artículo 11 de la Ley N. ${ }^{\circ} 1508$ (2012).

Asimismo, cuando se trate de proyectos de APP de iniciativa privada, el nivel de estudio es igual de exigente que para los proyectos de iniciativa pública, solo que, en este caso los estudios se dividen en dos etapas (pre factibilidad y de factibilidad) y los costos son asumidos por cuenta y riesgo del concesionario.

Los estudios requeridos para la aprobación de los proyectos son muy completos, pues incluyen los estudios de adquisición y expropiación, permitiendo así que el Estado colombiano tenga certeza de los costos y riesgos que le demandarán determinados proyectos, teniendo así mejor posición de negociación frente los inversionistas y mejorando la asignación de riesgos.

En resumen, podríamos decir que los problemas detectados en Colombia surgieron por la falta de los estudios adecuados para la licitación de los proyectos e incentivos para los inversionistas. Dicha situación se refleja en contratos que han sido renegociados, lo que afecta la operación de los proyectos, y con ello las finanzas públicas, ante los desembolsos no presupuestados por la falta de previsión (Mendiola et al., 2011). También es preciso señalar que la adquisición de predios fue un punto crítico en la concesión de proyectos viales ya que, Colombia, hasta el 2005 no contaban con una ley de expropiaciones, lo que en la práctica implicó grandes demoras en la inversión y en los avances físicos de la obra.

\section{- México}

Según González (2007), a partir de 1990, México aceleró la construcción de carreteras mediante el otorgamiento de cerca de medio centenar de concesiones viales otorgadas por dicho gobierno para la construcción, operación, explotación y conservación del sistema carretero. Se había previsto en el esquema concesionario de carreteras que, la inversión aportada por empresarios privados y bancos, sería recuperable y obtendrían un rendimiento dentro del plazo de concesión. Sin embargo, en 1997, el Estado mexicano implementó el Programa de Rescate Carretero ante la crisis económica iniciada en el país en los años 1994 y 1995, pues las empresas concesionarias se vieron seriamente afectadas como consecuencia de que sus ingresos no cubrían los gastos de mantenimiento; por ello, 
el programa tenía como objetivo evitar el deterioro de las carreteras dadas en concesión. Así, 23 concesiones fueron asumidas por el Gobierno mexicano, mientras que al resto se les extendió los plazos en un promedio de 20 años adicionales (Mendiola et al., 2011).

Según Mendiola et al (2011), la crisis de concesiones viales se debió a que se realizaron estudios incompletos que subestimaron el valor real de las concesiones cuyos costos, en promedio, sobrepasaron en más de 50\% lo proyectado; las empresas obtuvieron préstamos de corto y mediano plazo a tasas de interés variable; se incrementaron las tarifas de peaje, llegando a ser las más altas del mundo; y se otorgaba la concesión al licitante que ofrecía el menor periodo de concesión. En el 2003 se relanzaron las concesiones luego de la crisis experimentada. El nuevo esquema consideraba que las concesiones fuesen subsidiadas mediante un aporte estatal inicial y un apoyo en el servicio de la deuda. (p. 29)

Finalmente, es recién a partir del 16 de enero de 2012 que México aprueba la Ley de Asociaciones Público Privadas (2012), seguida por el Reglamento de la Ley de Asociaciones Públicas Privadas (2012), aprobada el 5 de noviembre de 2012.

\subsubsection{Reflexiones}

Hemos estudiado a países del continente americano que, al igual que el Perú durante los años noventa, tenían un contexto social inestable e infraestructura vial crítica, pero que, con la colaboración de los inversionistas privados, nacionales y extranjeros, y por medio de contratos de concesión vial (alianzas público privadas), lograron reducir la brecha en infraestructura de manera significativa. Colombia, Chile y México han sido reconocidos por The Economist Intelligence Unit como países líderes en concesiones viales en Latino América, por contar con un adecuado marco normativo en materia de concesiones viales y mantener una economía estable. Sin embargo, de acuerdo a lo investigado, hemos determinado que Colombia y Chile han desarrollado mejor los marcos legales referentes a gestión predial, pues han optimizado e institucionalizado dicho procedimiento en sus territorios. Entonces, siendo estos países los más representativos, es importante comprender la gestión del procedimiento de obtención de titularidad de áreas concesionadas en proyectos de infraestructura vial de los países mencionados. 


\subsection{Gestión predial en Chile y Colombia}

En la presente sección nuestro objetivo será comprender la gestión predial para proyectos de infraestructura vial en Chile y Colombia; para ello, estudiaremos las normas que regulan las adquisiciones y expropiaciones en dichos países, e identificaremos a los sujetos intervinientes; luego, estudiaremos el procedimiento de adquisición y expropiación que se lleva a cabo en ambos países; finalmente, identificaremos al sujeto (concedente y/o concesionario) responsable de los costos derivados de la gestión predial.

\subsubsection{En Chile}

A. Normas que regulan la gestión predial

El marco legal de la gestión predial para concesiones viales chilena se enmarca en: La Constitución Política de Chile (1978); el Decreto Ley Nº 2186 (1978), Ley Orgánica de Procedimiento de Expropiaciones; el Decreto con Fuerza de Ley $\mathrm{N}^{\circ}$ 850 (1978); y, el Decreto Ley $\mathrm{N}^{\circ} 900$ (1996), Ley de concesiones.

En el numeral 24 del artículo 19 de la Constitución Política de Chile (1978), se establece que nadie puede ser privado de su propiedad, salvo por ley general o especial que autorice la expropiación por causa de utilidad pública o de interés nacional, calificada por el legislador. Asimismo, el sujeto expropiado tiene derecho a reclamar sobre la legalidad del acto expropiatorio, y tiene derecho a ser indemnizado por el daño patrimonial causado, el mismo que podrá ser fijado de común acuerdo entre el expropiante y expropiado, o en sentencia de tribunal. En ese sentido, el D Decreto Ley $\mathrm{N}^{\circ} 2186$ (1978) establece en su artículo 2 los lineamientos con los que deberá contar la entidad autorizada para expropiar.

Por el DFL N 850 (1978) se precisa cuál es la entidad responsable de ejecutar las expropiaciones; y, por el Decreto Ley $N^{\circ} 900$ (1996), se precisa a quien corresponde asumir los desembolsos, gastos o expensas que se originen las adquisiciones, expropiaciones y limitaciones de la propiedad privada. 
B. Sujetos intervinientes en la gestión predial

El artículo 3 del DFL No 850 (1978) establece que el Ministerio de Obras Públicas (MOP) tiene a su cargo la expropiación de bienes para las obras de infraestructura. En ese sentido, el MOP ha creado la Unidad de Expropiaciones de la Dirección de Vialidad, el mismo que solo expropia caminos que son de competencia de dicha Dirección, ya sean Caminos Públicos Nacionales y Regionales. (Dirección de Vialidad del MOP, 2019)

C. Procedimientos para obtener la titularidad de predios en Chile

La adquisición de titularidad de predios en Chile puede ser realizado de dos formas: (i) por convenio, y (ii) por expropiación por vía judicial. El procedimiento por convenio es similar al procedimiento de adquisición regulado en la legislación peruana. De acuerdo a lo señalado en el Decreto Ley N. 2186 (1978), la gestión de ambos procedimientos está a cargo del Estado chileno, representado por el MOP.

Para iniciar la gestión predial de obras viales en Chile, la Dirección General de Concesiones del MOP (s.f./2) señala el siguiente procedimiento. Primero se requiere contar con el proyecto de lo que será la Obra Pública Concesionada, para luego elaborar el plano de las áreas sujetas a expropiación. Aprobado el plano, el MOP notifica al propietario afectado, indicando la superficie del predio que será necesario expropiar. Una comisión de tres peritos tasadores independientes visita el predio para efectuar la tasación del área que se necesita expropiar. La comisión portará un certificado que acredita su nombramiento. Con información de terreno y antecedentes de la propiedad, la comisión elabora un informe de tasación, indicando características de la propiedad, valor comercial del terreno y el valor de las construcciones. Posteriormente, el expropiado recibe una notificación por parte del MOP con copia del informe indicándole el valor de tasación y las oficinas del MOP donde debe acudir. Si hay acuerdo con la tasación, se procederá a la firma de un convenio en el que se individualiza la superficie a expropiar y se indica el monto final a pagar como indemnización. Firmado el convenio, el MOP efectúa los trámites 
administrativos, los cuales concluyen con la firma de la Escritura Pública de expropiación por parte del MOP y del expropiado y la posterior inscripción a nombre del Fisco del terreno expropiado en el Conservador de Bienes Raíces respectivo. Después de inscrita la propiedad a favor del Estado chileno, el MOP paga el valor acordado en el convenio. Si no existe acuerdo con la tasación, la expropiación será tramitada por vía judicial, oportunidad en la que se puede reclamar del monto fijado por los peritos, siendo los tribunales los encargados de fijar la indemnización definitiva, para lo cual tomarán en consideración los antecedentes presentados por el expropiado y el MOP. Mientras se desarrolla el proceso judicial, el juez puede ordenar que se pague al propietario expropiado la suma no disputada del monto de indemnización. Además, los tribunales pueden autorizar al MOP para que ingrese a terreno y ejecute las obras a pesar del procedimiento judicial en trámite.

A continuación, desarrollaremos cada etapa de la gestión predial descrita.

En Chile, la identificación de los predios es una actividad compartida, pues dentro de los procesos de licitación de los proyectos, las empresas precalificadas participan en el diseño definitivo de los mismos, proponiendo mejoras, adiciones o ajustes al diseño del proyecto. En caso sea necesario, el MOP podría solicitar la realización de estudios adicionales, los que serán considerados en la elaboración de las bases de la licitación del proyecto final y pagados por las empresas precalificadas $\mathrm{y}$, al culminar el proceso licitatorio, la empresa ganadora (concesionario) deberá devolver el monto sufragado al resto de participantes.

Para prevenir el rechazo social del proyecto de infraestructura, en Chile, los estudios preliminares incluyen un informe por el que se identifica la posible población afectada, así como proponen beneficios que se brindarán a la comunidad. Estos estudios, al igual que la identificación de predios, son realizados por el concedente en colaboración con el concesionario.

Respecto a la tasación de predios, en Chile se calcula el valor estimado de los predios a expropiar en la etapa de gestión predial, y es realizado por cuenta y riesgo de la entidad sobre la cual recaerá el proyecto vial. En el Estado chileno se habla de indemnización provisional e indemnización definitiva. La indemnización provisional es la valorización que ha recibido el inmueble por parte de la comisión 
tasadora; mientras que la indemnización definitiva es fijada de común acuerdo entre el expropiante y el expropiado, o por el tribunal competente. Asimismo, cabe precisar que el valor del bien inmueble es determinado mediante el método de análisis de mercado, es decir "Valor Comercial", el mismo que no considera el daño emergente ni lucro cesante.

La valuación de los predios es realizada por una comisión de tres miembros, la misma que determinará cual será el monto de la indemnización provisional. Los miembros de esta comisión son técnicos de diversas especialidades que figuran en una lista de peritos, que aprueba el Presidente de la República de Chile por decreto del Ministerio de Hacienda, para una región o agrupación de regiones, donde solo uno de los miembros puede pertenecer a la administración centralizada o descentralizada del Estado chileno, y no puede ser trabajador del MOP. De este modo, el Estado chileno pretende garantizar a los propietarios de los inmuebles a ser expropiados que la tasación de sus inmuebles es objetiva e imparcial.

La expropiación comienza con la notificación del MOP a los expropiados, previa visita de los Peritos Tasadores, con la Resolución que los nombra o la notificación de los valores tasados (Dirección de Vialidad del MOP, 2019). Una vez notificado el sujeto, que tiene dominio de la propiedad, está en condiciones de elegir entre los dos caminos que permite la Ley. La primera alternativa es firmar un convenio ad referéndum ${ }^{19}$, mediante un procedimiento de convenio; $y$, la segunda alternativa es solicitar la consignación judicial, e iniciar un procedimiento expropiatorio. Si el sujeto afectado por la expropiación aceptase la oferta de compra, el monto ofrecido puede pagarse al contado, en dinero, en otras especies de bienes, a plazo, en cuotas, etc.

Las formalidades del procedimiento de convenio están reguladas en los artículos 11 y 12 del Decreto Ley N. ${ }^{\circ} 2186$, se señala que el acuerdo debe contener la declaración de las partes (expropiante y expropiado) sobre el bien requerido,

${ }^{19}$ Convenio Ad Referéndum Directo de Precios es un acuerdo en virtud del cual las partes hacen entrega material de los terrenos necesarios para la ejecución de una obra pública, y convienen el monto de la indemnización definitiva a pagar por dichos terrenos, sujeto a la aprobación del acto administrativo correspondiente (Dirección de Vialidad del MOP, 2019). 
por el que el expropiado se compromete a entregar al expropiante la propiedad, posesión o dominio de su bien inmueble, en un breve periodo de tiempo. Asimismo, el acuerdo deberá constar por escritura pública. Otras formalidades propias del acuerdo son mencionar la fecha y numero de Diario Oficial en el que fue publicada la expropiación y la individualización del bien a ser expropiado. En caso los bienes se encuentren inscritos en registros públicos, se deberá insertar una copia de la inscripción de dominio, con certificado de vigencia del propietario expropiado, y una copia de un certificado de hipotecas, gravámenes, prohibiciones y litigios. Si los bienes y derechos necesarios para realizar las obras no han sido adquiridas por el concesionario en el procedimiento de convenio, se adquirirán vía expropiación judicial.

Cuando se trate de expropiación por vía judicial, el MOP también será el responsable de supervisar y ejecutar dicho procedimiento. Este se realizará conforme a lo establecido en el Decreto Ley Nº 2186 (1978).

Es preciso resaltar que el MOP garantiza al concesionario que, si el procedimiento expropiatorio se transforma en un reclamo judicial por parte del o de los expropiados, y genera un retraso en la entrega de los bienes con respecto a los plazos previstos, el MOP compensará al concesionario otorgándole un aumento en el periodo de concesión por el mismo lapso de retraso.

Finalmente, es posible que el expropiante y expropiado suscriban el convenio ad referéndum antes o durante el procedimiento de expropiación (siempre antes de que se haya dictado una sentencia definitiva), con el objetivo de adquirir los bienes inmuebles.

D. Asignación de los costos derivados de la gestión predial

El artículo 15 del Decreto Ley $\mathrm{N}^{\circ} 900$ (1996) precisa que, el Estado chileno es el responsable de la adquisición de los predios por la vía de expropiación judicial; sin embargo, tanto los costos para la adquisición directa, como para la obtención de los predios por la vía de expropiación judicial, están a cargo del concesionario. Dichos costos incluyen la tasación de los terrenos, así como los demás gastos necesarios para la transferencia de propiedad. Los valores de las tasaciones de las 
propiedades están incluidos en los "Proyectos Referenciales de Ingeniería Definitiva" entregados por el MOP al concesionario. Si los gastos exceden los montos señalados en las proyecciones, y no han sido asignadas al concesionario en las bases de licitación, deben ser asumidos por el MOP. Mientras que, si el concesionario es quien propone las modificaciones a los "Proyectos Referenciales de Ingeniería Definitiva", que requieran adquisiciones o expropiaciones adicionales a las contempladas en ellos y demanden un desembolso adicional (no incluido en la cifra anterior), será responsabilidad exclusiva del concesionario. Así también, en el Decreto Ley $N^{\circ} 900$ (1996) se señala que, el atraso en el cumplimiento de cualquiera de los pagos para la adquisición y expropiación, que estuviesen a cargo del concesionario, tendrá como consecuencia el pago de multas, según lo convenido en los contratos de concesión vial.

En la práctica, según señalan Hayal y Mendoza (2014), "ha sido frecuente que el Estado, a través de las Bases de Licitación propuestas por el MOP en diversos proyectos, asuma un alto porcentaje de este, o incluso su totalidad, particularmente cuando supera el valor ofertado en la licitación” (p. 143); es decir, el concesionario no siempre asume la totalidad de los costos de la gestión predial como se señala en la norma. Esto demuestra que la asignación de los costos de la gestión predial es negociable y flexible, según determinada obra de infraestructura.

\subsubsection{En Colombia}

A. Normas que regulan la gestión predial

La obtención de predios en el Estado colombiano puede ser realizado de tres formas: (i) enajenación voluntaria, (ii) expropiación por vía judicial o (iii) expropiación por vía administrativa ${ }^{20}$.

${ }^{20}$ La expropiación por vía administrativa es reconocida en la Constitución Política colombiana. Este es un mecanismo que permite transferir la propiedad de los bienes inmuebles privados al Estado colombiano, justificado en la utilidad pública, interés social y la necesidad de urgencia. 
La expropiación por vía judicial se regula por: La Constitución Política de Colombia (1991); la Ley N. 9 (1989), Ley de Reforma Urbana; la Ley Nº 388 (1997), Ley de Desarrollo Territorial; y, la Ley N.o 1564, Código General del Proceso colombiano.

El artículo 58 de la Constitución Política de Colombia (1991) señala que el Estado garantiza "la propiedad privada y los demás derechos adquiridos con arreglo a las leyes civiles, los cuales no pueden ser desconocidos ni vulnerados por leyes posteriores." Sin embargo, "por motivos de utilidad pública o interés social definidos por el legislador, podrá haber expropiación mediante sentencia judicial e indemnización previa. Esta se fijará consultando los intereses de la comunidad y del afectado. En los casos que determine el legislador, dicha expropiación podrá adelantarse por vía administrativa, sujeta a posterior acción contenciosa-administrativa, incluso respecto del precio."

En el Capítulo III de la Ley $N^{\circ} 9$ (1989), se regula el procedimiento de adquisición de bienes por enajenación voluntaria y por expropiación por la vía judicial. La Ley $\mathrm{N}^{\circ} 388$ (1997) modificó algunos procedimientos de la expropiación judicial regulada en la Ley $\mathrm{N}^{\circ} 9$ (1989), y reguló expresamente la adquisición. Mientras que, los artículos 451 y 459 del Código de Procedimiento Civil colombiano (1970), contienen las normas generales del procedimiento para expropiar por la vía judicial.

La expropiación por la vía administrativa solo se ejecuta en casos específicos determinadas por el legislador, siempre que sea por "motivos de utilidad pública o de interés social”, de acuerdo a lo establecido en el artículo 63 de la Ley $\mathrm{N}^{\circ} 388$ (1997), y que, "la respectiva autoridad administrativa competente considere que existen especiales condiciones de urgencia". En ese sentido, en el art. 19 de la Ley $N^{\circ} 105$ (1993), Por la cual se adoptan medidas y disposiciones para los proyectos de infraestructura de transporte y se conceden facultades extraordinarias, define como "motivo de utilidad pública e interés social [a] la ejecución y/o desarrollo de proyectos de infraestructura del transporte[...], así como el desarrollo de las actividades relacionadas con su construcción, mantenimiento, rehabilitación o mejora, quedando autorizada la 
expropiación administrativa o judicial de los bienes e inmuebles urbanos y rurales que se requieran para tal fin."

Entonces, cuando se realice la expropiación administrativa, se deberán considerar los lineamientos establecidos en la Ley N. ${ }^{\circ} 1682$ (2013), Por la cual se adoptan medidas y disposiciones para los proyectos de infraestructura de transporte y se conceden facultades extraordinarias, y la Ley N. ${ }^{o} 1742$ (2014), Por la cual se adoptan medidas y disposiciones para los proyectos de infraestructura de transporte, agua potable y saneamiento básico, y los demás sectores que requieran expropiación en proyectos de inversión que adelante el Estado y se dictan otras disposiciones.

\section{B. Sujetos intervinientes en la gestión predial}

El artículo 11 de la Ley N. 9 (1989), modificado por el artículo 59 de la Ley N. ${ }^{\circ}$ 388 (1997), precisa que las Entidades Estatales competentes: “[L]a Nación, las entidades territoriales, las áreas metropolitanas y asociaciones de municipios", pueden adquirir por: (i) Enajenación voluntaria o, (ii) mediante decreto, la expropiación de los bienes inmuebles ubicados sobre las áreas concesionadas. Así también, las sociedades de economía mixta (tales como las creadas por la regulación de las APP), que estén expresamente facultadas por sus propios estatutos para ejecutar la gestión predial, también podrían adquirir o decretar la expropiación de bienes inmuebles para el desarrollo de las adquisiciones o expropiaciones. Así mismo, el concedente y concesionario deberán pactar dichas obligaciones en el contrato de concesión.

Teniendo en consideración esta alternativa que brindaba la normativa interna, respecto a la adquisición de bienes inmuebles, la Agencia Nacional de Infraestructura $(\mathrm{ANI})^{21}$ ha diseñado un único modelo de contrato de cuarta

\footnotetext{
${ }^{21}$ En Colombia, desde noviembre de 2011, la ANI tiene por objeto planear, coordinar, estructurar, contratar, ejecutar, administrar y evaluar proyectos de concesiones y otras formas de Asociación Público Privada, para el diseño, construcción, mantenimiento, operación, administración y/o explotación de la infraestructura pública de transporte en todos sus modos y de los servicios conexos o relacionados y el desarrollo de proyectos de asociación público privada para otro tipo de infraestructura pública cuando así lo determine expresamente el Gobierno Nacional respecto de infraestructuras semejantes relacionados a las
} 
generación, basado en las normas de expropiación y en su marco normativo de APP. De este contrato resalta el "Apéndice Técnico N. ${ }^{\circ}$ 7: Gestión predial”, por el que se detallan las condiciones establecidas en el procedimiento de adquisición y/o expropiación de los inmuebles privados o públicos sobre los cuales se construirán los proyectos viales. Cabe precisar que el Apéndice Técnico $\mathrm{N}^{\circ} 7$ ha unificado el diverso marco legal colombiano que regula las adquisiciones y expropiaciones.

En el Apéndice Técnico $\mathrm{N}^{\circ} 7$ se señala de forma clara que, la gestión predial para la ejecución de las obras de infraestructura vial, se encuentra a cargo del concesionario, quien desarrolla dicha labor en favor y en representación de la ANI. Sin embargo, cabe la posibilidad de que el concedente y el concesionario distribuyan el riesgo de distintas formas, según cada etapa de la gestión predial. Mientras tanto, algunas de las funciones de la ANI consisten en impartir las directrices generales para llevar a cabo el desarrollo de la gestión predial y/o supervisar que el concesionario realice correctamente la gestión predial; comunicar a las entidades públicas vinculadas para el desarrollo del proyecto; y, definir el tipo de expropiación que se ejecutará para la adquisición de predios, en caso no se pueda realizar vía enajenación voluntaria (adquisición).

\section{Procedimiento para obtener la titularidad de predios en Colombia}

De acuerdo a lo desarrollado anteriormente, la obtención de predios en el Estado colombiano puede ser realizada por enajenación voluntaria, expropiación por vía judicial o expropiación por vía administrativa.

La enajenación voluntaria es similar al procedimiento de adquisición por trato directo del Estado peruano, pues consiste en verificar los estudios de identificación de inmuebles, así como del expediente técnico legal, elaborar y 
notificar una "Oferta formal de compra" al titular de la propiedad inmueble, esperar la aceptación de la oferta para suscribir e inscribir la compraventa del bien inmueble. Sin embargo, difiere del Estado peruano en que, el Estado colombiano no brinda un incentivo por la suscripción del trato directo; y, si el titular de la propiedad inmueble no aceptase la oferta, el ANI (en representación del Estado colombiano) y en coordinación con el concesionario, decidirán si se procede con la expropiación por la vía administrativa o la expropiación vía judicial.

El procedimiento de enajenación voluntaria tiene como principal actor al concesionario, quien tiene entre sus funciones conformar o contratar un grupo de profesionales de gestión predial, bajo su propio costo y riesgo, que le permitan desarrollar el plan de adquisición de predios, realizar la demarcación de los linderos del área a adquirir para el proyecto vial, determinar los costos de adquisición de los predios correspondientes al proyecto, para lo cual debe contratar a una empresa especializada ${ }^{22}$, que realizará los avalúos comerciales corporativos (las tasaciones) según los lineamientos establecidos por el Instituto Geográfico Agustín Codazzi (Ley N. ${ }^{\circ} 1682,2013$ ). Cabe precisar que el avalúo comercial (tasación) incluye el valor de las indemnizaciones, o compensaciones, como resultado de la afectación del derecho de propiedad de los particulares. La tasación es efectuada en un plazo máximo de 6 meses, y los costos que demanden las tasaciones son atribuidos al concesionario (Ley N. ${ }^{\circ}$ 1450, 2011).

Asimismo, el concesionario debe determinar los costos de cercar las áreas adquiridas, garantizar que los predios aledaños al proyecto queden con el acceso necesario que les permita su normal desarrollo y acceso, y gestionar la oferta de compra con los titulares o poseedores de los bienes inmuebles deseados que se encuentren en las áreas concesionadas.

Para prevenir el rechazo social de la obra de infraestructura vial, el concesionario desarrolla planes y actividades de gestión social, según los

${ }^{22}$ El gremio o lonja de propiedad raíz a contratar por el Concesionario para la realización de los Avalúos Comerciales Corporativos, además de las obligaciones y condiciones establecidas en la Ley Aplicable sobre la materia, debe cumplir con determinados requisitos, tales como experiencia en el mercado no menor de 8 años; el gremio o lonja de propiedad raíz a contratar por el Concesionario para la realización de los Avalúos Comerciales Corporativos, además de las obligaciones y condiciones establecidas en la Ley Aplicable sobre la materia. (Ley 1682, 2013) 
parámetros establecidos en el Apéndice 8 del contrato de concesión colombiano. Algunos de los objetivos de la gestión social son:

- Desarrollar planes y actividades que reduzcan o mitiguen los impactos negativos y potencien los impactos positivos en las comunidades relacionadas con el Proyecto.

- Crear relaciones de credibilidad y confianza con las comunidades del área de influencia del proyecto.

- Promover en las comunidades la apropiación, respeto y sentido de pertenencia de las obras que se adelantan, así como el establecimiento de canales de participación de las comunidades en torno al proyecto.

Cuando se haya realizado la oferta de compra por parte del concedente, y el titular de la propiedad inmueble no aceptase la oferta, la ANI (en representación del Estado colombiano), en coordinación con el concesionario, deberán decidir si se procede con la expropiación por la vía administrativa o la vía judicial.

En caso la ANI decidiera llevar a cabo el proceso de expropiación por vía administrativa, el concesionario deberá elaborar el proyecto de acto administrativo mediante el cual se declara la expropiación del Predio, el cual deberá cumplir con los requisitos previstos para este acto en la Ley Aplicable, y entregarlo al Interventor ${ }^{23}$. El Interventor formulará sus observaciones; y la ANI definirá, al momento de suscribir el correspondiente acto administrativo, si adopta o no las observaciones efectuadas por el Interventor. En todo caso, el acto administrativo mediante el cual se declara la expropiación por vía administrativa, deberá ser publicado treinta días después desde que hubiere quedado firme el acto administrativo mediante el cual se efectuó la oferta formal de compra. Ejecutoriado el acto administrativo mediante el cual se declara la expropiación por vía administrativa, el concesionario procederá con la inscripción en el registro de instrumentos públicos correspondientes. Asimismo, el concesionario

23 El Interventor es quien realiza el seguimiento técnico a la ejecución de los contratos estatales colombianos. Puede ser una persona natural o jurídica, y es contratada por la entidad contratante mediante un contrato de interventoría. 
adelantará todas las actividades e interpondrá las acciones previstas en la ley aplicable, necesarias para obtener la tenencia efectiva del predio, incluyendo la solicitud de intervención de las autoridades de policía.

En una expropiación por vía judicial, el concesionario actuará como apoderado de la ANI para efectos de los trámites de expropiación judicial, y será responsable por el adecuado desarrollo del Proceso.

La demanda de expropiación es presentada por el concesionario en calidad de apoderado de la ANI. En la demanda de expropiación, el concesionario deberá solicitar la entrega anticipada del predio deseado; también estará a cargo del proceso de expropiación judicial, y será el responsable de la realización de todas las actuaciones judiciales hasta que el Juez ordene la inscripción de la sentencia mediante el cual se otorga la titularidad a la ANI, y se registre en el respectivo folio de matrícula inmobiliaria, previa cancelación de todos los valores ordenados por el Juzgado.

Así mismo, durante el proceso de expropiación judicial, siempre y cuando no se haya dictado sentencia definitiva, es posible que el titular del derecho real de dominio y el concesionario lleguen a un acuerdo, el cual no podrá modificar los términos iniciales de adquisición, en cuyo caso se pondrá fin al proceso judicial.

D. Asignación de los costos derivados de la gestión predial

En Colombia, todos los costos vinculados a la gestión predial para la obtención de las áreas concesionadas se encuentran a cargo del concesionario. Este aporta los recursos para la adquisición de los predios y las compensaciones socioeconómicas, mediante el traslado de los recursos necesarios a una subcuenta de predios, administrada por una fiduciaria. Los recursos de la subcuenta de predios son utilizados única y exclusivamente para los pagos a los propietarios de los predios y para la aplicación del plan de compensaciones socioeconómicas. Sin embargo, si los costos del valor estimado de predios y compensaciones socioeconómicas son insuficientes para la adquisición de los predios, los costos 
adicionales al valor estimado de predios y compensaciones socioeconómicas podrían ser asumidos en su totalidad por la ANI.

Asimismo, a fin de incentivar que el concesionario negocie de manera eficiente con los propietarios, en Colombia, se prevé la posibilidad de otorgar al concesionario el $60 \%$ del ahorro provocado en la cuenta predial, siempre que: (i) más del ochenta por ciento $(80 \%)$ de los predios se hayan adquirido por enajenación voluntaria ya sea durante el proceso de expropiación o antes, y (ii) no se hubieren requerido aportes adicionales de la ANI.

\subsubsection{Cuadro comparativo}

De acuerdo a lo desarrollado en el presente capitulo, hemos identificado que Chile y Colombia son los países más representativos y con mayores avances en la legislación sobre gestión predial para obras de infraestructura vial; motivo por el cual hemos realizado estudios sobre la gestión predial que emplean ambos países. Como resultado del estudio de las normas y contratos que regulan la gestión predial chilena y colombiana, hemos identificado a los principales actores, y las medidas preventivas adoptadas por estos países, que sirven para afrontar los principales factores de riesgos en los procedimientos de adquisición y expropiación. A continuación, presentaremos el cuadro resumen comparativo. 
Tabla 4.1

Cuadro comparativo de la gestión predial en concesiones viales de Chile y Colombia

\begin{tabular}{|c|c|c|}
\hline $\begin{array}{l}\text { Factor } \\
\text { de riesgo } \\
\end{array}$ & Chile & Colombia \\
\hline $\begin{array}{c}\text { Modalidades para } \\
\text { obtener la titularidad } \\
\text { de predios }\end{array}$ & (i) Por convenio, y (ii) por expropiación por vía judicial. & $\begin{array}{l}\text { (i) Enajenación voluntaria, (ii) expropiación por vía } \\
\text { judicial o (iii) expropiación por vía administrativa. }\end{array}$ \\
\hline $\begin{array}{c}\text { Responsables de } \\
\text { obtener la titularidad } \\
\text { de predios }\end{array}$ & $\begin{array}{l}\text { Estado Chileno (concedente), con posibilidad de que el } \\
\text { concesionario actúe en su representación en la } \\
\text { modalidad de adquisición por convenio. }\end{array}$ & $\begin{array}{l}\text { Estado Colombiano (concedente), con posibilidad de } \\
\text { que el concesionario actúe en su representación en } \\
\text { cualquiera de las modalidades. }\end{array}$ \\
\hline $\begin{array}{l}\text { Identificación de } \\
\text { predios que serán } \\
\text { concesionados }\end{array}$ & $\begin{array}{l}\text { Actividad compartida entre el concedente y el } \\
\text { concesionario. }\end{array}$ & $\begin{array}{l}\text { Actividad realizada por el concesionario, en } \\
\text { representación del concedente. }\end{array}$ \\
\hline $\begin{array}{l}\text { Medidas para } \\
\text { prevenir el rechazo } \\
\text { social del proyecto } \\
\text { de infraestructura }\end{array}$ & $\begin{array}{l}\text { Se realizan estudios durante la preparación del proyecto } \\
\text { sobre los beneficios de la población afectada. }\end{array}$ & $\begin{array}{l}\text { Se desarrollan planes y actividades de gestión social } \\
\text { del proyecto. }\end{array}$ \\
\hline $\begin{array}{l}\text { Responsable de } \\
\text { prevenir el rechazo } \\
\text { social del proyecto } \\
\text { de infraestructura }\end{array}$ & $\begin{array}{l}\text { Actividad realizada bajo responsabilidad del concedente } \\
\text { y concesionario. }\end{array}$ & $\begin{array}{l}\text { Actividad realizada por el concesionario, en } \\
\text { representación del concedente. }\end{array}$ \\
\hline \begin{tabular}{|c|}
$\begin{array}{c}\text { Elaboración del } \\
\text { expediente técnico } \\
\text { legal }\end{array}$ \\
\end{tabular} & Actividad realizada bajo responsabilidad del concedente. & $\mid \begin{array}{l}\text { Actividad realizada bajo responsabilidad del } \\
\text { concesionario, en representación del concedente. }\end{array}$ \\
\hline Tasación de predios & Actividad realizada bajo responsabilidad del concedente. & $\begin{array}{|llll|}\text { Actividad realizada bajo responsabilidad del } \\
\text { concesionario, en representación del concedente. }\end{array}$ \\
\hline $\begin{array}{c}\text { Sistema de } \\
\text { tasación de predios }\end{array}$ & $\begin{array}{l}\text { Los inmuebles son tasados por una comisión tasadora, } \\
\text { dando el monto de la indemnización provisional; y, la } \\
\text { indemnización definitiva es fijada de común acuerdo } \\
\text { entre el expropiante y expropiado (cuando se realice por } \\
\text { enajenación voluntaria), o por el Juez (cuando se realice } \\
\text { por expropiación judicial). }\end{array}$ & $\begin{array}{l}\text { Los inmuebles son tasados por el concesionario o una } \\
\text { empresa especializada contratada por el concesionario, } \\
\text { de acuerdo con los lineamientos de la normatividad } \\
\text { interna. El contratista determinará el valor comercial del } \\
\text { inmueble. }\end{array}$ \\
\hline $\begin{array}{c}\text { Supervisión de la } \\
\text { tasación }\end{array}$ & Supervisión realizada por el concedente. & $\begin{array}{l}\text { Supervisión realizada por el concesionario y por el } \\
\text { concedente. }\end{array}$ \\
\hline $\begin{array}{c}\text { Asignación de los } \\
\text { costos de la gestión } \\
\text { predial }\end{array}$ & $\begin{array}{l}\text { Los costos derivados para la adquisición directa y la } \\
\text { expropiación vía judicial son obligaciones del } \\
\text { concesionario. Si los gastos exceden los montos } \\
\text { proyectados, y no han sido asignadas al concesionario } \\
\text { en las bases de licitación, deben ser asumidos por el } \\
\text { MOP. }\end{array}$ & $\begin{array}{l}\text { Los costos derivados para la adquisición directa y la } \\
\text { expropiación vía judicial o vía administrativa son } \\
\text { obligaciones del concesionario. Si los gastos exceden } \\
\text { los montos proyectados, y no han sido asignadas al } \\
\text { concesionario en las bases de licitación, deben ser } \\
\text { asumidos por la ANI. }\end{array}$ \\
\hline
\end{tabular}

Fuente: La Constitución Política de Chile (1978); el Decreto Ley N$^{\circ} 2186$ (1978), Ley Orgánica de Procedimiento de Expropiaciones; el Decreto con Fuerza de Ley $\mathrm{N}^{\circ} 850$ (1978); el Decreto Ley $\mathrm{N}^{\circ} 900$ (1996), Ley de concesiones; La Constitución Política de Colombia (1991); la Ley N. ${ }^{\circ} 9$ (1989), Ley de Reforma Urbana; la Ley N ${ }^{\circ} 388$ (1997), Ley de Desarrollo Territorial; y, la Ley N. ${ }^{\circ}$ 1564, Código General del Proceso colombiano.

Elaboración Propia

\section{En resumen:}

- En el Estado chileno; según marco legal interno, el procedimiento por convenio (adquisición) y de expropiación judicial, son de responsabilidad del mismo Estado; y, los costos derivados de la gestión predial, son de responsabilidad del 
concesionario. Mientras que, en los contratos, los costos son derivados hacia el concedente.

- En el Estado colombiano; según marco legal interno, el procedimiento de enajenación voluntaria (adquisición) y de expropiación judicial y administrativa es responsabilidad del Estado; sin embargo, es posible pactar vía contractual que sea el concesionario quien dirija y ejecute la gestión predial en representación del Estado, siempre bajo la supervisión de este último; y, los costos que deriven de dicho procedimiento, también serán asumidos por el concesionario.

\subsection{Conclusiones del Cuarto Capítulo}

Teniendo en consideración lo estudiado en la sección anterior, realizaremos un análisis comparado de las medidas adoptadas en Chile, Colombia y Perú, para afrontar los principales factores de riesgos que influyen en el éxito de la gestión predial.

\section{- Modalidades para obtener la titularidad de predios}

De acuerdo al análisis realizado, el procedimiento de adquisición por trato directo (en Perú), es similar al procedimiento de adquisición por convenio (en Chile), y al procedimiento de enajenación voluntaria (en Colombia), pues consisten en lograr la titularidad de un predio mediante la suscripción de un acuerdo, sin recurrir al procedimiento de expropiación. Tanto en Chile, como en Colombia, brindan incentivos al sujeto pasivo de la gestión predial y al concesionario, para que logren obtener la titularidad de los predios concesionados a través de los procedimientos por convenio o enajenación voluntaria, según corresponda a cada país.

Los procedimientos de expropiación judicial de Chile y Colombia difieren del procedimiento de expropiación judicial de Perú; pues, en estos procedimientos se puede discutir el valor indemnizatorio de tasación hecha al bien inmueble concesionado, e inclusive la razón misma del objeto de expropiación. Sin embargo, en Perú solo se puede discutir el valor indemnizatorio producto de la tasación, el mismo que puede realizarse vía judicial o vía arbitral. Por ello, concluimos que el procedimiento de expropiación de Perú es similar al procedimiento de expropiación administrativa de Colombia. El mismo que es promovido por el Estado colombiano cuando se desea adquirir áreas concesionadas que corresponden a obras de infraestructura vial. 
Cabe precisar que, si en Perú una expropiación es realizada sin cumplir con el requisito principal: necesidad pública o interés nacional, el sujeto pasivo de dicha adquisición o expropiación podrá recurrir a instancias judiciales o arbitrales, y discutir el objeto de la expropiación.

\section{- Responsables de obtener la titularidad de predios}

Los únicos dotados de facultades para ejercer el Ius Imperium son los Estados, por tanto, Chile, Colombia y Perú son los principales responsables de obtener la titularidad de predios que se encuentren en las áreas concesionadas dentro de sus territorios. Estos Estados pueden obtener la titularidad de predios por el procedimiento de adquisición o su equivalente en cada país.

En Chile y Colombia, la gestión predial puede ser ejecutada por el concedente en colaboración con el concesionario, o este último puede actuar en representación de los intereses del Estado. Mientras que, solo en Colombia el concesionario puede actuar en representación del Estado en los procedimientos de expropiación administrativa, y como impulsador, en los procedimientos de expropiación judicial y administrativa.

En el Perú, el concedente solo está facultado para colaborar de forma parcial en el procedimiento de adquisición, pero no para actuar en representación del Estado, ni está facultado para actuar como impulsador en el procedimiento de expropiación vía judicial o arbitral.

\section{- De la identificación de predios}

En Colombia y Chile, la identificación de predios es realizada en colaboración conjunta entre el concedente y concesionario, durante la elaboración de los Estudios Definitivos de Ingería, los mismos que son entregados antes de la suscripción del contrato de concesión vial. Mientras que, en el Perú el concedente es el responsable de identificar los predios, procedimiento que no se encuentra delimitado de forma clara. Entonces, en la práctica, la identificación de predios se realiza después de la elaboración de los Estudios Definitivos de Ingeniería; es decir, posterior a la suscripción del contrato de concesión vial. 


\section{- Medidas para prevenir el rechazo social del proyecto de infraestructura}

En Chile y Colombia se consideran los estudios de impacto social dentro del informe preliminar de los proyectos de infraestructura vial. Desde la formación del proyecto se empieza a interactuar con la población que se verá afectada por la obra de infraestructura vial. La intervención se realiza de forma activa, generando sentido de permanencia entre los miembros de la comunidad afectada sobre el proyecto. Cabe precisar que dichos estudios son realizados y ejecutados por el Estado, en colaboración con los postulantes del proceso de licitación.

Por tanto, el factor de riesgo de rechazo social del proyecto de infraestructura puede ser afrontado preventivamente, y el Estado peruano puede prevenirlo realizando estudios de impacto social o PACRI, tal y como lo hacen en Colombia y Chile.

\section{- De la elaboración del expediente técnico}

De acuerdo a lo desarrollado, en el Perú, la elaboración del expediente técnico legal para obras de infraestructura vial, es responsabilidad de Provias Nacional, entidad que actúa en representación del Estado. A diferencia del Estado chileno, quien traslada la responsabilidad de elaborar el expediente técnico legal al concesionario, y éste lo realiza bajo supervisión del mismo Estado. En el Estado colombiano, por norma se han establecido los lineamientos técnicos y la experiencia con la que debe contar la empresa privada que llevará a cabo la elaboración del expediente técnico, sea esta empresa el concesionario o un contratista de este último.

Entonces, ni en Chile ni en Colombia es el Estado quien realiza la gestión predial, sino un contratista. Considerando ello, es posible optimizar la gestión predial peruana si es que se imita el procedimiento de elaboración del expediente técnico de estos países, trasladando la responsabilidad de elaborar dichos expedientes al inversionista privado.

El numeral 23.2 del artículo 23 del D. Leg. N. ${ }^{\circ}$ 1192, permite trasladar la responsabilidad de elaborar los expedientes técnico legal al concesionario por la vía contractual; por tanto, quedaría pendiente que, en la práctica, se aproveche este artículo para así mejorar la gestión predial. 


\section{- Responsables de la tasación}

En el Perú, las tasaciones son ejecutadas y auto supervisadas por el MVCS, entidad estatal. Esta entidad ha sido duramente criticada por las demoras en realizar la entrega de las valorizaciones de los bienes inmuebles solicitados para proyectos de infraestructura vial. Consideramos que esto se debe a que en la actualidad el MVCS realiza las valorizaciones de bienes inmuebles que provienen de todas partes del país y de distintos proyectos de infraestructura. Es por esta razón que consideramos oportuno que la ejecución de las tasaciones sea realizada por un contratista especializado, al igual que se realiza en el Estado colombiano.

\section{- Del sistema de tasación de los predios}

Respecto a la tasación de predios, hemos logrado identificar que cada país tiene una forma distinta de ejecutarla. El sistema de tasación chileno contrata tres peritos para realizar las valuaciones de los bienes inmuebles. Mientras que, el Estado colombiano deriva dicha responsabilidad al concesionario, quien lo puede hacer por cuenta propia o puede contratar a una empresa especializada según requisitos establecidos por Ley. Como se desarrolló en el capítulo anterior, la tasación en el Perú es realizada por un Perito adscrito al Ministerio de Vivienda, Construcción y Saneamiento (MVCS) que es elegido por la Dirección de Construcción de dicho Ministerio.

Con relación al sistema de tasación, podría considerarse ventajoso el empleado en Chile por contar con tres peritos para realizar las valuaciones de los bienes inmuebles; pero, aunque el sistema de tasación chileno es bueno, sería alto el costo para el Estado peruano porque encarecería el costo final del proyecto a licitar y, por tanto, sería menos atractivo para los inversionistas. Mientras tanto, en Colombia, el sistema de tasación traslada completamente la responsabilidad al concesionario, pudiendo este último realízalo por su cuenta y riesgo, o trasladando la obligación a un contratista.

Teniendo en consideración la experiencia extranjera, consideramos oportuno que el Perú, al igual que en Colombia, opte porque sean las empresas especializadas las que realicen las tasaciones de los bienes inmuebles; que sea el concesionario quien asuma en 
primera instancia los costos para realizar dichas tasaciones, y que, dependiendo del proyecto de infraestructura vial, se evalúe si este será reintegrado por el concedente o formará parte del costo total del proyecto.

Con relación al valor final de la tasación, hemos identificado que Colombia y Chile solo consideran el valor comercial del inmueble, a diferencia de Perú, que considera dentro de la tasación el daño emergente y el lucro cesante.

\section{- De los costos derivados del procedimiento de adquisición y expropiación}

Como hemos estudiado, los costos derivados de la gestión predial en Chile y Colombia son asumidos por el concesionario, previniendo así la escasez de recursos y evitando posibles demoras en los pagos de las indemnizaciones a realizarse cuando se ejecuten las adquisiciones y/o expropiaciones.

A diferencia de estos países, el Estado peruano, con el D. Leg. N. ${ }^{\circ} 1192$, a través del numeral 23.4, artículo 23, establece que los costos derivados de la adquisición de los bienes inmuebles afectados, pueden ser negociados en los contratos de asociación público privada. Sin embargo, lo único que puede ser negociado es la forma de pago.

Teniendo en consideración la experiencia extranjera, es posible mejorar derivación de costos en la gestión predial con la participación del concesionario.

Con relación a las modificaciones a los Estudios Definitivos de Ingeniería, por los que se propone la adquisición de nuevas áreas no contempladas en los primeros estudios, la normativa no precisa como se debe proceder; sin embargo, en los contratos de concesión vial peruanos se pactó reiteradas veces que estos se realizan por costo y riesgo del concedente, ya sea por sugerencia del mismo concedente o del concesionario. Dicha condición difiere del marco legal de Chile y Colombia, pues en estos países los costos y riesgos se asignan según el origen que motive el cambio solicitado. Por tanto, consideramos que el marco legal peruano debería regular este factor de riesgo según sea lo más favorable para el Estado y sus ciudadanos. 


\section{CONCLUSIONES}

De acuerdo a la investigación y análisis realizado en los capítulos anteriores de nuestro trabajo de investigación, hemos llegado a la conclusión que las implicancias legales para asignar un nuevo rol al concesionario, que optimice los procedimientos de adquisición y expropiación en los contratos de concesión vial, son: i) Armonizar y, por tanto, modificar el D. Leg. N. ${ }^{\circ} 1192$ (2015), Decreto Legislativo N. ${ }^{\circ} 1362$ (2018) y , las Directrices para la elaboración y aplicación del PACRI (2004); ii) Incorporar, de acuerdo a los factores de éxito, el nuevo rol participativo del concesionario en los procedimientos de adquisición y expropiación de los contratos de concesión vial, que permitan prevenir los factores de riesgo; e, iii) Incorporar la participación activa del concesionario, desarrollada en el marco legal, en los contratos de concesión vial, suscritos y/o por suscribirse.

El concesionario tiene interés en liberar las áreas concesionadas lo más pronto posible porque solo de esta manera podrá ejecutar la obra de infraestructura que se ha obligado a ejecutar por el contrato de concesión vial suscrito con el Estado; y, de esta manera podrá recuperar la inversión realizada y obtener las ganancias esperadas. Así mismo, el concesionario tiene las herramientas legales y económicas para acelerar la gestión predial, a diferencia del Estado. Por tanto, se optimizará los procedimientos de adquisición y expropiación de los contratos de concesión vial cuando el marco legal peruano promueva la participación del concesionario en la gestión predial, al igual que se viene ejecutando en Chile y Colombia; así como, cuando el nuevo rol del concesionario en el marco legal peruano se vea reflejado en los contratos de concesión vial.

De acuerdo a lo desarrollado en el Capítulo II, la Constitución Política del Perú permite obtener la titularidad de predios de dos formas: Por el procedimiento de adquisición por trato directo y por el procedimiento de expropiación. Para efectos de nuestra investigación, a estos procedimientos los hemos denominado en conjunto gestión predial.

El procedimiento de adquisición está conformado por las siguientes etapas: Identificación de predios, identificación del sujeto pasivo, elaboración del expediente técnico legal, tasación de predios, presentación de la oferta de adquisición, que incluye 
el incentivo económico adicional del $20 \%$ sobre el valor de tasación. Si, el sujeto pasivo de la gestión predial acepta la oferta de adquisición, estos firmarán el acuerdo de adquisición por trato directo y se realizará la inscripción registral del bien inmueble. Los sujetos pasivos desalojarán el bien inmueble o, de lo contrario, se procederá con el procedimiento de ejecución coactiva. Si el sujeto pasivo de la gestión predial rechazara la oferta de adquisición, terminará el procedimiento de adquisición.

El procedimiento de expropiación inicia con el rechazo de la oferta de adquisición, siempre que se haya publicado la ley autoritativa por el congreso, y está conformado por las siguientes etapas: Publicación de la norma que aprueba la ejecución de expropiación del bien inmueble y el valor de la tasación, sin incluir el incentivo económico adicional; depósito de la consignación sobre el valor de la tasación publicada; notificación notarial o judicialmente al sujeto pasivo sobre la publicación realizada y sobre el pago de la tasación; finalmente, la inscripción registral de la expropiación. Los sujetos pasivos deberán entregar el bien inmueble expropiado, pudiendo ser realizado previo acuerdo con el sujeto activo, de lo contrario, se seguirá el procedimiento de ejecución coactiva.

De acuerdo a lo desarrollado, sabemos que la gestión predial inicia con la identificación de predios; sin embargo, las derogadas normas que regulaban la gestión predial, no precisaban cuando debía iniciar esta fase; y, como es de esperarse, tampoco se señalaba en los contratos de concesión vial. El nuevo marco legal de las Adquisiciones y Expropiaciones, D. Leg. N. ${ }^{\circ} 1192$, sí establece cuando debe iniciar a más tardar la fase de identificación de predios.

De igual modo ha sucedido con los Planes de Compensación y Reasentamiento Involuntario para Proyectos de Infraestructura de Transporte (PACRI). Pese a que, las Directrices para la elaboración y aplicación del PACRI han sido reguladas por el MTC en el 2004, estas no fueron consideradas por el D. Leg. N. ${ }^{\circ} 1192$, ni las derogadas normas que regulaban las concesiones viales, el Decreto Legislativo N.o 1012 (2008) y su reglamento, el Decreto Supremo N. ${ }^{\circ}$ 127-2014-EF (2014); y el Decreto Legislativo N. ${ }^{\circ}$ 1224 (2015) y su reglamento, el Decreto Supremo N. ${ }^{\circ}$ 410-2015-EF (2015). A diferencia de las normas mencionadas, el Decreto Legislativo N. ${ }^{0} 1362$ (2018) sí ha precisado que el MTC se encuentra facultado de ejecutar el PACRI., cuando sea necesario. Este cambio permitirá promocionar el PACRI entre las futuras concesiones viales, lo que optimizará la gestión predial pues se podrán prevenir el rechazo social, facilitará la inspección ocular 
de las viviendas, facilitará la realización de tasaciones, y mejorará las condiciones de negociación entre el sujeto activo y sujeto pasivo de la gestión predial. Sin embargo, para garantizar la ejecución de los PACRI, su implementación debe ser obligatoria siempre que sea necesario ejecutar la gestión predial; así como, debe ampliarse la posibilidad de que los PACRI puedan ser elaborados por el concesionario.

Respecto a la tasación de predios en la gestión predial, es facultad del MTC solicitar la elaboración de la tasación de los inmuebles necesarios para la ejecución de sus proyectos de infraestructura, a peritos u organismos especializados en el rubro, con reconocida y acreditada experiencia. Los mismos que actuarán de acuerdo al Reglamento Nacional de Tasaciones y la normatividad vigente; y, el MTC será solidariamente responsable de los actos de estos peritos y/u organismos. Consideramos que este cambio facilitará obtener las valorizaciones de los inmuebles, pues se dejará de depender el MVCS; sin embargo, está pendiente otorgar un roll participativo al concesionario en la tasación de predios.

Asimismo, si bien se han establecido los criterios por los que se deberá elegir a los peritos o entidades tasadoras, así como, sea ha precisado que el MTC será la entidad encargada de supervisarla, aún está pendiente que se delimite qué pasará en caso de que no se cumplan con las disposiciones establecidas en el Reglamento Nacional de Tasaciones y la normatividad vigente; y, que se determine si se les será aplicable penalizaciones por incumplimiento. Cabe precisar que el sistema de tasación de predios está diseñado para realizar la valorización comercial individual de cada bien inmueble. Teniendo en consideración ello, es necesario que también se mejore el criterio de tasaciones, y así permitir la rápida y eficiente valorización de predios.

De acuerdo al marco legal vigente, la gestión predial para obras de infraestructura vial se encuentra a cargo del MTC, quien actúa en representación del Estado peruano y es denominado sujeto activo de la gestión predial. Mientras que, el concesionario, denominado también “inversionista" en la gestión predial, tiene la posibilidad de colaborar con la elaboración del expediente técnico legal, y de efectuar la implementación, gestión y/o culminación del procedimiento de adquisición por trato directo. Sin embargo, en la mayoría de los contratos de concesión vial el concesionario tiene un rol limitado, pues es el Estado quien tiene la responsabilidad de ejecutar el procedimiento de adquisición. Solo en algunos contratos se acordó que sea el 
concesionario quien identifique a los sujetos pasivos, elabore los expedientes técnicos de los inmuebles a expropiar, y realice los pagos compensatorios, que posteriormente fueron reintegrados por el Estado al concesionario.

Teniendo en consideración la situación descrita, concluimos que es necesario que los contratos de concesión vial que aún se encuentran trabados por la falta de entrega de predios, se adecúen al D. Leg. N. ${ }^{\circ} 1192$, y aprovechen las facilidades que brinda dicha norma, para que sea el concesionario quien impulse el trato directo en el procedimiento de adquisición. Así como, para que, en los futuros contratos de concesión vial, se convenga desde su suscripción toda la colaboración posible por parte del concesionario en la gestión predial.

De acuerdo a lo desarrollado en el Capítulo III, los principales factores de éxito del procedimiento de obtención de titularidad de áreas concesionadas son lograr obtener la titularidad de áreas concesionadas en el tiempo más breve posible; y, que el sujeto pasivo de la gestión predial sea compensado adecuadamente por la pérdida de su derecho de propiedad. Estos factores de éxito permitirán identificar al Estado peruano, cuáles son las medidas más adecuada para afrontar los factores de riesgo de las concesiones viales.

De acuerdo al análisis exhaustivo realizado sobre la Adenda N ${ }^{\circ} 1$ del contrato de concesión vial Quilca, la Adenda N. ${ }^{\circ} 2$ del contrato de concesión vial Autopista el Sol y la opinión de los expertos entrevistados, concluimos que los principales factores de riesgos del procedimiento de obtención de titularidad de áreas concesionadas son: Plazos reducidos acordados para realizar la entrega de titularidad, posibilidad de rechazo social del proyecto a ejecutarse, problemas para identificar los bienes inmuebles afectados por el Derecho de Vía, problema para identificar a los sujetos pasivos, demora para elaborar el expediente técnico legal, demora en realizar las valorizaciones de los bienes inmuebles, valor compensatorio que no está de acuerdo a los intereses del sujeto pasivo, demora en gestionar el trato directo, problema de liquidez económica para realizar pagos compensatorios a los sujetos pasivos de la gestión predial, y, demora en gestionar los pagos compensatorios.

Algunos de los factores de riesgo de la gestión predial en los contratos de concesión vial han sido afrontados mediante medidas correctivas, incorporadas al contrato a través de las adendas estudiadas. Es decir, se incurría en incumplimiento contractual (sobre factores de riesgo que pudieron haber sido previstos) y posteriormente 
se proponían soluciones. Esta situación ha perjudicado al Estado peruano con sobrecostos adicionales y generando retrasos para la adecuada ejecución de las obras de infraestructura vial.

Se analizó también el proyecto en cartera "Infraestructura vial Longitudinal de la Sierra Tramo 4", y hemos identificado que el Estado ha implementado mejoras en la gestión predial. Algunas mejoras que identificamos son: Ampliación de los plazos de entrega de las áreas concesionadas; promoción del procedimiento de adquisición por trato directo; y asignación al concesionario como el responsable, por cuenta propia o contratando a un contratista, de identificar los bienes inmuebles afectados por el Derecho de Vía, identificar a los sujetos pasivos y elaborar los expedientes técnicos, de un determinado tramo.

Por lo expuesto, concluimos que el nuevo rol del concesionario en los contratos de concesión vial impactará positivamente en la gestión predial, pues la experiencia en otros contratos de concesión vial ha demostrado que el concesionario toma las medidas adecuadas para afrontar dichos factores de riesgo. Sin embargo, el Estado debe adoptar más medidas preventivas en los contratos de concesión vial que estén acorde con los factores de riesgo y, principalmente, con los factores de éxito identificados.

Como resultado de los estudios realizados en el Capítulo IV sobre el desarrollo de la infraestructura vial en países de América Latina, hemos identificado que Chile y Colombia, al igual que Perú, tenían un contexto social inestable e infraestructura vial crítica, pero que, con la colaboración de los inversionistas privados, nacionales y extranjeros, y por medio de contratos de concesión vial (alianzas público privadas), lograron reducir la brecha en infraestructura de manera significativa. Asimismo, sus marcos normativos sobre gestión predial han desarrollado formas estratégicas de afrontar y prevenir los factores de riesgos, principalmente cuando se tratan de obras de infraestructura vial.

Con relación al desarrollo de la gestión predial en Chile y Colombia hemos identificado lo siguiente:

- En Chile, el procedimiento para obtener la titularidad áreas concesionaras se puede realizar de dos formas: (i) por convenio, y (ii) por expropiación por vía judicial. El responsable de obtener la titularidad de los predios es el concedente, el Ministerio de Obras Públicas quien actúa en representación del Estado chileno; 
con la posibilidad de que el concesionario actúe en su representación en la modalidad de adquisición por convenio. La identificación de los predios es una actividad compartida entre el concedente y el concesionario. Con relación a las medidas para prevenir el rechazo social del proyecto de infraestructura vial, el concedente es el responsable de realizar los estudios durante la preparación del proyecto.

La tasación de predios se encuentra bajo responsabilidad del concedente, y son realizados por una comisión tasadora, dando el monto de la indemnización provisional; y, la indemnización definitiva es fijada de común acuerdo entre el expropiante y expropiado (cuando se realice por enajenación voluntaria), o por el Juez (cuando se realice por expropiación judicial).

Los costos derivados para la adquisición directa y la expropiación vía judicial son obligaciones del concesionario. Si los gastos exceden los montos proyectados, y no han sido asignadas al concesionario en las bases de licitación, deben ser asumidos por el MOP.

- En Colombia, el procedimiento para obtener la titularidad áreas concesionaras se puede realizar de tres formas: (i) enajenación voluntaria, (ii) expropiación por vía judicial o (iii) expropiación por vía administrativa. El responsable de obtener la titularidad de los predios es el concedente, la Autoridad Nacional de Infraestructura (ANI) quien actúa en representación del Estado chileno, con posibilidad de que el concesionario actúe en su representación en cualquiera de las formas.

Las medidas para prevenir el rechazo social del proyecto de infraestructura vial, la identificación de predios, la elaboración de los expedientes técnico legal y la tasación de predios son realizados por el concesionario, en representación del concedente.

Con relación a la tasación de predios, los inmuebles son tasados por el concesionario o una empresa especializada contratada por el concesionario, según las condiciones establecidas por su normativa interna.

Los costos derivados para la adquisición directa y la expropiación vía judicial o vía administrativa son obligaciones del concesionario; $\mathrm{y}$, si los gastos exceden los 
montos proyectados y no han sido asignadas al concesionario en las bases de licitación, deben ser asumidos por la ANI.

Como podemos observar, ambos países han creado una única entidad especializada que ejecuta y supervisa todas las fases por las que atraviesa una APP, las mismas que consideran a la gestión predial como una fase relevante del proyecto de infraestructura. Por ejemplo, en Chile la entidad responsable es la Dirección General de Concesiones del MOP; mientras que, en Colombia, es la ANI. Los marcos legales de ambos países, referentes a la gestión predial, se encuentran en armonía con las normas que regulan a las asociaciones público privadas; así como, han adoptado medidas para prevenir el rechazo social del proyecto y que, promueven la adquisición por trato directo (convenio o enajenación voluntaria, según cada país) en obras de infraestructura vial. También hemos identificado que ambos países han optado por ejecutar la gestión predial en colaboración con el concesionario; o, como en Colombia, trasladar al concesionario la responsabilidad total de ejecutar la gestión predial en representación del Estado.

Entonces, teniendo en consideración los roles asumidos por los concesionarios en los contratos de concesión vial chileno y colombiano, según marco legal, y los buenos resultados obtenidos, podemos concluir que es posible optimizar los procedimientos de adquisición y expropiación, designando un nuevo rol al concesionario en los contratos de concesión vial peruanos, siempre que el marco legal y los futuros contratos adopten medidas preventivas estratégicas frente a los factores de riesgo identificados anteriormente. 


\section{RECOMENDACIONES}

Teniendo en consideración las conclusiones de la presente investigación, recomendamos que el marco legal peruano promueva la participación del concesionario en la gestión predial; y que, dicho marco legal se vea reflejado en los futuros contratos de concesión vial a suscribirse.

Asimismo, se debe implementar mejoras y realizar cambios al D. Leg. N. 1192 que fortalezcan la gestión predial, para ello proponemos las siguientes mejoras al rol del concesionario en los procedimientos de adquisición y expropiación en los contratos de concesión vial.

- Primero, la adecuación del D. Leg. N. ${ }^{\circ}$ 1192, el Decreto Legislativo N. 1362 (2018) y las Directrices para la Elaboración y Aplicación de Planes de Compensación y Reasentamiento Involuntario para Proyectos de Infraestructura de Transporte (2004), poniéndolas en armonía para que contribuyan con la celeridad de la gestión predial, así como, permitan la participación del concesionario.

- Segundo, recomendamos que la nueva participación del concesionario considere los factores de éxito identificados en nuestra investigación, desde el diseño del contrato hasta la negociación de los términos en los futuros contratos de concesión vial.

- Tercero, proponemos las siguientes medidas preventivas para afrontar cada uno de los factores de riesgo identificados en nuestra investigación:

- Establecer plazos adecuados para la entrega de las áreas concesionadas, ya sea por parte del concedente al concesionario o viceversa, según dimensiones de las áreas requeridas y las condiciones registrales en las que se encuentran las mismas.

- Con relación a los problemas para identificar las áreas concesionadas, recomendamos que esta fase de la gestión predial se ejecute antes de la fase de transacción de la concesión, tanto para las asociaciones público privadas cofinanciadas como para las autofinanciadas, con el objetivo de estimar el plazo necesario para la entrega de las áreas concesionadas antes de iniciar la 
transacción con el concesionario. Así como, recomendamos que la identificación de predios se realice en colaboración conjunta entre el concedente y los concursantes en el proceso de licitación.

- Como desarrollamos anteriormente, son los inversionistas quienes cuentan con mejor capacidad económica y tecnológica para verificar que, la información de los Estudios Preliminares, corresponde con la realidad de cada inmueble. El concesionario puede validar la información técnica, física, socio-económica y jurídica de cada uno de los inmuebles requeridos para la ejecución del proyecto; así como, los inversionistas pueden redefinir, de manera precisa, el área requerida en cada predio y, por tanto, también puede definir la existencia de áreas sobrantes y áreas remanentes, previas a la suscripción del contrato de concesión.

- Con el fin de prevenir las demoras en identificar a los sujetos pasivos, demoras en la elaboración del expediente técnico legal, demoras en realizar las valorizaciones de los bienes inmuebles, demoras en gestionar el trato directo y el posible rechazo de la población afectada por la concesión, recomendamos realizar estudios de impacto social e implementar el PACRI, según las necesidades de la población afectada, y en todos los contratos de concesión vial en los que será necesario realizar la gestión predial. Así como, recomendamos permitir participar activamente al concesionario en la elaboración de los PACRI.

- Cuando el valor compensatorio no está de acuerdo a los intereses del sujeto pasivo, se debe brindar la posibilidad de que sujeto pasivo discuta el valor compensatorio por la vía judicial o arbitral, mientras dispone del dinero correspondiente a la indemnización compensatoria, condición que debería poder ser pactada por un acuerdo adicional al trato directo. De esta manera se logrará contar con la transferencia registral y disponibilidad física del bien inmueble, mientras que por la vía judicial o arbitral se discute el valor final del bien inmueble.

- Con relación al problema de liquidez económica para realizar pagos compensatorios a los sujetos pasivos de la gestión predial, y, demora en gestionar los pagos compensatorios, recomendamos que este factor de riesgo sea afrontado con medidas preventivas en los contratos de concesión vial, por 
las que se establezca que sea el concesionario el responsable de realizar los pagos compensatorios cuando sean necesarios para el éxito de la gestión predial, gastos que le podrán ser devueltos por el concedente, según condiciones de la licitación. Esta medida preventiva debe ser negociada en la fase de transacción en la concesión vial.

- Con relación a la solicitud de adquisición de nuevos predios por la modificación de los Estudios Definitivos de Ingeniería, los riesgos y costos que estos demanden deben regularse en el D. Leg. N. ${ }^{\circ}$ 1362; caso contrario, las adendas que se suscriban, deben considerar la asignación de riesgos, según las causas que motivaron la solicitud.

- Cuarto, recomendamos que, a través de una modificación a la Ley Marco de Adquisición y Expropiación, se brinde la posibilidad al concesionario de participar activamente en todo el procedimiento de adquisición, y en representación del Estado peruano; así como, que se brinde al concesionario la posibilidad de participar como impulsador en todo el procedimiento de expropiación.

Adicionalmente, en aras de mejorar los procedimientos de adquisición y expropiación en concesiones viales y solucionar otras problemáticas identificadas durante nuestra investigación, compartimos algunas recomendaciones adicionales:

- Realizar la pronta adecuación normativa que establezca el inicio de la identificación de predios afectados por la concesión vial en el Decreto Legislativo N. 1362 (2018).

- Precisar si son, o no, sujetos pasivos los poseedores con menos de diez años sobre los bienes privados estatales, en consideración con la Ley N. ${ }^{\circ} 29618$.

- Realizar pronta regulación normativa sobre la facultad que tiene el MTC para solicitar la tasación de inmuebles a peritos u organismos especializados.

- Plasmar en los futuros contratos de concesión vial, desde la fase de estructuración de la concesión, las facilidades que les brinda la Ley Marco de Adquisición y Expropiación, tal y como se ha implementado sutilmente en el proyecto de contrato Longitudinal de la Sierra Tramo 4. 
- Recomendamos que la responsabilidad de ejecutar y/o supervisar la gestión predial de las concesiones viales se centre en una única entidad, tal como se realiza en Colombia y Chile, con el objetivo de mantener el control de la gestión predial.

- Así también, recomendamos que se elabore un anexo único para los contratos de concesión vial, en los que consolide todas las fases de los procedimientos de adquisición y expropiación, y considere la máxima participación del concesionario posible; tal como se realiza en el Estado colombiano.

Finalmente, recomendamos a ProInversión, MTC, OSITRAN y MEF tener en consideración las propuestas planteadas en nuestras recomendaciones; así como, pedimos al Poder Legislativo evaluar el siguiente proyecto de ley (Adjunto en el Anexo A), propuesto en aras de optimizar los procedimientos de adquisición y expropiación y contando con la intervención del concesionario. 


\section{REFERENCIAS}

Agencia de Promoción de la Inversión Privada, ProInversión. (s.f.). En ProInversión. Recuperado el 10 de diciembre de 2018, de sitio de Internet: https://www.proyectosapp.pe/modulos/JER/PlantillaProyecto.aspx?ARE=0\&PF $\mathrm{L}=2 \& \mathrm{JER}=5845 \& \mathrm{SEC}=22$

Avendaño, F. (25, noviembre, 2014). Bienes de dominio privado del Estado: ¿imprescriptibles? IUS 360. Recuperado del sitio de Internet: http://ius360.com/jornadas/jornada-por-los-30-anos-del-codigo-civil/bienes-dedominio-privado-del-estado-imprescriptibles/

Bernales Ballesteros, E. (1999). La Constitución de 1993: Análisis Comparado. Lima: Editora Rao

Castillo, L. (2006). El derecho de propiedad como objeto de protección del proceso de amparo. Normas legales: análisis jurídico: doctrina, jurisprudencia, consultas, documentos, 2 (360), pp. 165-180.

Coordinación de Concesiones de Obras Públicas. (2016). Concesiones de Obras Públicas en Chile. 20 años. [versión PDF]. Recuperado de http://www.concesiones.cl/Documents/libro-Concesiones_obras-publicas-chile20.pdf

Cusato, A. y Pastor C. (2008). Lecciones del Mantenimiento de Carreteras en el Perú, 1992 - 2007. Recuperado del sitio de Internet del Instituto Peruano de Economía: http://ipe.org.pe/wp-content/uploads/2009/08/ipe-lecciones-del-mantenimientode-carreteras-en-el-peru-1992-2007.pdf

Dirección de Vialidad del Ministerio de Obras Públicas. (08, febrero, 2019). Preguntas frecuentes. Información jurídica. Recuperado de http://www.vialidad.cl/areasdevialidad/Expropiaciones/Paginas/default.aspx

García-Toma, Víctor. (1998). Análisis Sistemático de la Constitución Peruana de 1993, Tomo II. Lima: Universidad de Lima, Fondo de Desarrollo Editorial.

Gerencia de Regulación y Estudios Económicos de OSITRAN. (2018). Informe de desempeño 2017. Concesión del tramo vial: Dv. Quilca - Dv. Arequipa (Respartición) - Dv. Matarani - Dv. Moquegua - Dv. Ilo- Tacna- La Concordia. Lima.

Gerencia de Regulación y Estudios Económicos de OSITRAN. (2018/2). Informe de desempeño 2017. Concesión del tramo vial: Trujillo - Sullana. Lima. 
González Rodríguez, J. (2007). Las concesiones de las autopistas mexicanas, examen de su vertiente legislativa. México D.F.: Centro de Estudios Sociales y de Opinión Pública.

Hayal, J. y Mendoza, D. (2014). CONTRATOS DE CONCESIONES DE OBRAS PÚBLICAS: El régimen jurídico de la concesión durante la fase de construcción de la obrar Recuperado de http://repositorio.uchile.cl/bitstream/handle/2250/129791/Contratos-deconcesiones-de-obras-p\%C3\%BAblicas.pdf;sequence $=1$

Martin Tirado, R. (2007). Expropiaciones y concesiones sobre obras públicas de infraestructura y de servicios públicos: la experiencia peruana. Jus Doctrina y Práctica, (No 8), Pp. 383-395.

Mendiola, A.; Alvarado F.; Chocano, Z; Cotrado, A.; García, L. y Aguirre, C. (2011). Factores críticos de éxito en concesiones viales en el Perú (1. ${ }^{a}$ ed.). Lima.: Universidad ESAN.

Organismo Supervisor de la Inversión en Infraestructura de Transporte de Uso Público, OSITRAN. (2018). Recuperado del sitio de Internet de OSITRAN: https://www.ositran.gob.pe/carreteras/

Provias Nacional. (s.f.). En Provias Nacional. Recuperado el 03 de julio de 2018, de sitio de Internet: https://www.pvn.gob.pe/nosotros/

Provias Nacional/2. (s.f.). En Provias Nacional. Recuperado el 01 de marzo de 2019, de sitio de de Internet: http://www.proviasnac.gob.pe/frmPlanesyPresupuestos.aspx?idmenu=718

Rufián Lizana, D. M. (2002). Políticas de concesión vial: análisis de las experiencias de Chile, Colombia y Perú. Santiago de Chile: Instituto Latinoamericano y del Caribe de Planificación Económica y Social (Ilpes) / Cepal.

Sentencia N. ${ }^{\circ}$ 0008-2003-AI/TC (Lima). (2003). Tribunal Constitucional de Perú. Recuperado de sitio de internet del Tribunal Constitucional de Perú: https://www.tc.gob.pe/jurisprudencia/2003/00008-2003-AI.html

Sentencia N. o 37/1987 (Madrid). (1987). Tribunal Constitucional de España. Recuperado de sitio de internet del Tribunal Constitucional de España: http://hj.tribunalconstitucional.es/es-ES/Resolucion/Show/769

Soria, F. (2018). Nuevas Modificaciones a la Ley Marco de Adquisición y expropiación de inmuebles: Siguiendo la búsqueda de un proceso expeditivo y facilitador para proyectos de infraestructura. IUS 360. Recuperado del sitio de Internet: http://ius360.com/publico/administrativo/nuevas-modificaciones-la-ley-marcode-adquisicion-y-expropiacion-de-inmuebles-siguiendo-la-busqueda-de-unproceso-expeditivo-y-facilitador-para-proyectos-de-infraestructura/ 
The Economist Intelligence Unit. (2017). Evaluating the environment for public-private partnerships in Latin America and the Caribbean: The 2017 Infrascope [Evaluación del entorno para las alianzas público-privadas en América Latina y el Caribe: El Infrascope 2017]. EIU, New York, NY.

World Bank Group. (18, Setiembre, 2016).Concesión, Proyectos de ConstrucciónOperación-Traspaso (BOT), Proyectos de Diseño-Operación-Construcción (DBO). Recuperado del sitio de Internet: https://ppp.worldbank.org/publicprivate-partnership/es/asociaciones-publico-privadas/acuerdos/concesionconstruccion-operacion-traspaso 


\section{REFERENCIAS NORMATIVAS}

Constitución Política de Chile. (09 de junio de 1978). Recuperado del sitio de internet de la Biblioteca del Congreso Nacional de Chile: https://www.leychile.cl/Consulta/m/norma_plana?idNorma=6848\&org=nxc2\%3 Fid_c\%3D1027

Constitución Política de Colombia. (13 de junio de 1991). Recuperado del sitio de internet de Corte Constitucional del Gobierno colombiano: http://www.corteconstitucional.gov.co/inicio/Constitucion\%20politica\%20de\%2 0Colombia.pdf

Constitución Política del Perú. (29 de diciembre de 1993). Recuperado del sitio de internet del Sistema Peruano de Información Jurídica: http://spij.minjus.gob.pe

Convención Americana Sobre Derechos Humanos. (22 de noviembre de 1969). Recuperado del sitio de internet de la Organización de los Estados Americanos: https://www.oas.org/dil/esp/tratados_b-

$\underline{32 \text { convencion_americana_sobre_derechos_humanos.htm }}$

Declaración Americana de los Derechos y Deberes del Hombre. (1948). Recuperado del sitio de internet de la Organización de los Estados Americanos: https://www.oas.org/dil/esp/Declaraci\%C3\%B3n_Americana_de_los_Derechos _y_Deberes_del_Hombre_1948.pdf

Declaración Universal de Derechos Humanos. (10 de diciembre de 1948). Recuperado del sitio de internet de Naciones Unidas: https://www.ohchr.org/EN/UDHR/Documents/UDHR_Translations/spn.pdf

Decreto con Fuerza de Ley $N^{\circ} 850$ del MOP. (25 de febrero de 1978). Recuperado del sitio de internet de la Biblioteca del Congreso Nacional de Chile: https://www.leychile.cl/Consulta/m/norma_plana?idNorma=6848\&org=nxc2\%3 Fid_c\%3D1027

Decreto Legislativo N. ${ }^{\circ}$ 1012, Decreto Legislativo que aprueba la ley marco de asociaciones público - privadas para la generación de empleo productivo y dicta normas para la agilización de los procesos de promoción de la inversión privada. (13 de mayo de 2008). Recuperado del sitio de internet del Sistema Peruano de Información Jurídica: http://spij.minjus.gob.pe

Decreto Legislativo $\mathrm{N}^{\circ}$ 1192, Ley Marco de Adquisición y Expropiación de inmuebles, transferencia de inmuebles de propiedad del Estado, liberación de interferencias y dicta otras medidas para la ejecución de obras de infraestructura. (23 de agosto 
de 2015). Recuperado del sitio de internet del Sistema Peruano de Información Jurídica: http://spij.minjus.gob.pe

Decreto Legislativo $\mathrm{N}^{\circ}$ 1210, Decreto Legislativo que modifica la Décima Disposición Complementaria Final del Decreto Legislativo $N^{\circ}$ 1192. (23 de Setiembre de 2015). Recuperado del sitio de internet del Sistema Peruano de Información Jurídica: http://spij.minjus.gob.pe

Decreto Legislativo $\mathrm{N}^{\circ}$ 1224, Decreto Legislativo del Marco de Promoción de la Inversión Privada mediante Asociaciones Público Privadas y Proyectos en Activos. (25 de Setiembre de 2015). Recuperado del sitio de internet del Sistema Peruano de Información Jurídica: http://spij.minjus.gob.pe

Decreto Legislativo $\mathrm{N}^{\circ}$ 1362, Decreto Legislativo que regula la Promoción de la Inversión Privada mediante Asociaciones Público Privadas y Proyectos en Activos. (23 de julio de 2018). Recuperado del sitio de internet del Sistema Peruano de Información Jurídica: http://spij.minjus.gob.pe

Decreto Legislativo $\mathrm{N}^{\circ} 1366$, Decreto Legislativo que modifica el Decreto Legislativo $\mathrm{N}^{\circ}$ 1192, que aprueba la Ley Marco de Adquisición y Expropiación de Inmuebles, Transferencia de Inmuebles de Propiedad del Estado, Liberación de Interferencias y dicta otras medidas para la ejecución de obras de infraestructura. (23 de julio de 2018). Recuperado del sitio de internet del Sistema Peruano de Información Jurídica: http://spij.minjus.gob.pe

Decreto Legislativo No 295, Código Civil. (25 de julio de 1984). Recuperado del sitio de internet del Sistema Peruano de Información Jurídica: http://spij.minjus.gob.pe

Decreto Legislativo $\mathrm{N}^{\mathrm{o}}$ 313, Ley general de expropiación. (25 de julio de 1984). Recuperado del sitio de internet del Sistema Peruano de Información Jurídica: http://spij.minjus.gob.pe

Decreto Ley $\mathrm{N}^{\circ}$ 2186, Ley Orgánica de Procedimiento de Expropiaciones. (09 de junio de 1978). Recuperado del sitio de internet de la Biblioteca del Congreso Nacional de

Chile: https://www.leychile.cl/Consulta/m/norma_plana?idNorma=6848\&org=nxc2\%3 Fid_c\%3D1027

Decreto Ley $\mathrm{N}^{\circ} 900$ del MOP, Ley de concesiones. (18 de diciembre de 1996). Recuperado del sitio de internet de la Biblioteca del Congreso Nacional de Chile: https://www.leychile.cl/Consulta/m/norma_plana?idNorma=6848\&org=nxc2\%3 Fid c\%3D1027

Decreto $N^{\circ}$ 1400, Código de Procedimiento Civil colombiano. (06 de agosto de 1970). Recuperado del sitio de internet de la Secretaría Jurídica Distrital de la Alcaldía Mayor de Bogotá

D.C.: https://www.alcaldiabogota.gov.co/sisjur/normas/Norma1.jsp?i=6923 
Decreto Supremo N. ${ }^{\circ}$ 011-2019-Vivienda, Texto Único Ordenado del Decreto Legislativo N. ${ }^{\circ}$ 1192. (12 de marzo de 2019). Recuperado del sitio de internet del Sistema Peruano de Información Jurídica: http://spij.minjus.gob.pe

Decreto Supremo N. ${ }^{\circ}$ 047-85-PCM, Reglamento del Decreto Legislativo No 313, Ley General de Expropiación. (22 de junio de 1985). Recuperado del sitio de internet del Sistema Peruano de Información Jurídica: http://spij.minjus.gob.pe

Decreto Supremo N. ${ }^{\circ}$ 059-96-PCM, Texto único ordenado de las normas con rango de ley que regulan la entrega en concesión al sector privado de las obras públicas de infraestructura y de servicios públicos. (26 de diciembre de 1996). Recuperado del sitio de internet del Sistema Peruano de Información Jurídica: http://spij.minjus.gob.pe

Decreto Supremo N. ${ }^{\circ}$ 127-2014-EF, Reglamento del Decreto Legislativo $N^{\circ} 1012$ que aprueba la ley marco de asociaciones público - privadas para la generación de empleo productivo y dicta normas para la agilización de los procesos de promoción de la inversión privada. (31 de mayo de 2014). Recuperado del sitio de internet del Sistema Peruano de Información Jurídica: http://spij.minjus.gob.pe

Decreto Supremo No 130-2001-EF, Dictan medidas reglamentarias para que cualquier entidad pública pueda realizar acciones de saneamiento técnico, legal y contable de inmuebles de propiedad estatal. (04 de julio de 2001). Recuperado del sitio de internet del Sistema Peruano de Información Jurídica: http://spij.minjus.gob.pe

Decreto Supremo N. ${ }^{\circ}$ 240-2018-EF, Reglamento del Decreto Legislativo $N^{\circ} 1362$, Decreto Legislativo que regula la Promoción de la Inversión Privada mediante Asociaciones Público Privadas y Proyectos en Activos. (30 de octubre de 2018). Recuperado del sitio de internet del Sistema Peruano de Información Jurídica: http://spij.minjus.gob.pe

Decreto Supremo $N^{\circ}$ 410-2015-EF, Reglamento del Decreto Legislativo $\mathrm{N}^{\circ} 1224$, Decreto Legislativo del Marco de Promoción de la Inversión Privada mediante Asociaciones Público Privadas y Proyectos en Activos. (27 de diciembre de 2015). Recuperado del sitio de internet del Sistema Peruano de Información Jurídica: http://spij.minjus.gob.pe

Ley de Asociaciones Público Privadas. (16 de enero de 2012). Recuperado del sitio de internet de la Cámara de Diputados: http://www.diputados.gob.mx/LeyesBiblio/ref/lapp.htm

Ley $\mathrm{N}^{\circ}$ 1450, Por la cual se expide el Plan Nacional de Desarrollo, 2010-2014. (16 de julio de 2011). Recuperado del sitio de internet: https://wipolex.wipo.int/es/text/226358

Ley $\mathrm{N}^{\circ} 1508$, Por la cual se establece el régimen jurídico de las Asociaciones Público Privadas, se dictan normas orgánicas de presupuesto y se dictan otras disposiciones. (10 de enero de 2012). Recuperado del sitio de internet de Departamento Nacional de Planeación del Gobierno de Colombia: https://www.dnp.gov.co/programas/participaci\%C3\%B3n-privada-\%20y-en- 
proyectos-de-infraestructura/asociaciones-publico-privadas/Paginas/marconormativo-app.aspx

Ley $N^{\circ}$ 1564, Código General del Proceso colombiano. (12 de julio de 2012). Recuperado del sitio de internet: https://app.vlex.com/\#vid/391649121

Ley $\mathrm{N}^{\circ} 1682$, Por la cual se adoptan medidas y disposiciones para los proyectos de infraestructura de transporte y se conceden facultades extraordinarias. (22 de noviembre de 2013). Recuperado de sitio de internet: http://www.suinjuriscol.gov.co/viewDocument.asp?ruta=Leyes/1686323

Ley $\mathrm{N}^{\circ}$ 1742, Por la cual se adoptan medidas y disposiciones para los proyectos de infraestructura de transporte, agua potable y saneamiento básico, y los demás sectores que requieran expropiación en proyectos de inversión que adelante el Estado y se dictan otras disposiciones. (26 de diciembre de 2014). Recuperado de sitio de internet de la Secretaría Jurídica Distrital de la Alcaldía Mayor de Bogotá D.C.: https://www.ani.gov.co/sites/default/files/ley_1742.pdf

Ley $\mathrm{N}^{\mathrm{o}} 26512$, Ley por la que declaran de necesidad y utilidad pública el saneamiento legal de los inmuebles de propiedad de los Sectores Educación y Transportes, Comunicaciones, Vivienda y Construcción. (02 de julio de 2001). Recuperado del sitio de internet del Sistema Peruano de Información Jurídica: http://spij.minjus.gob.pe

Ley $\mathrm{N}^{\circ}$ 27117. Ley General de Expropiaciones. (20 de mayo de 1999). Recuperado del sitio de internet del Sistema Peruano de Información Jurídica: http://spij.minjus.gob.pe

Ley N. ${ }^{\circ} 27628$, Ley que facilita la ejecución de obras públicas viales. (9 de enero de 2002). Recuperado del sitio de internet del Sistema Peruano de Información Jurídica: http://spij.minjus.gob.pe

Ley $\mathrm{N}^{\circ} 29618$, Ley que establece la presunción de que el Estado es poseedor de los inmuebles de su propiedad y declara imprescriptibles los bienes inmuebles de dominio privado estatal. (24 de noviembre de 2010). Recuperado del sitio de internet del Sistema Peruano de Información Jurídica: http://spij.minjus.gob.pe

Ley $\mathrm{N}^{\circ} 30025$, Ley que facilita la adquisición, expropiación y posesión de bienes inmuebles para obras de infraestructura y declara de necesidad pública la adquisición o expropiación de bienes inmuebles afectados para la ejecución de diversas obras de infraestructura. (22 de mayo de 2013). Recuperado del sitio de internet del Sistema Peruano de Información Jurídica: http://spij.minjus.gob.pe

Ley $\mathrm{N}^{\circ} 30327$, Ley de promoción de las inversiones para el crecimiento económico y el desarrollo sostenible. (21 de mayo de 2015). Recuperado del sitio de internet del Sistema Peruano de Información Jurídica: http://spij.minjus.gob.pe

Ley N 388, Ley de Desarrollo Territorial. (18 de julio de 1997). Recuperado del sitio de internet: 
http://www.ideam.gov.co/documents/24024/26915/C_Users_JGomez_Documen ts_ley_388_1997.pdf/8e64686e-09e1-4396-b0d1-70f23abe8fb3

Ley $\mathrm{N}^{\circ}$ 9, Ley de Reforma Urbana. (11 de enero de 1989). Recuperado del sitio de internet:

https://www.dapboyaca.gov.co/descargas/Normatividad_Pots/ley\%209\%201989 . .pdf

Pacto Internacional de Derechos Económicos, Sociales y Culturales. (16 de diciembre de 1966). Recuperado del sitio de internet de Naciones Unidas: https://www.ohchr.org/SP/ProfessionalInterest/Pages/CESCR.aspx

Reglamento de la Ley de Asociaciones Público Privadas. (5 de noviembre de 2012). Recuperado del sitio de internet de la Cámara de Diputados de México: http://www.diputados.gob.mx/LeyesBiblio/ref/regla.htm

Resolución Ministerial N 172-2016-VIVIENDA. (23 de julio de 2016). Recuperado del sitio de internet del Sistema Peruano de Información Jurídica: http://spij.minjus.gob.pe

Resolución Ministerial 763-2018-MTC/01. (01 de octubre de 2018). Recuperado del sitio de internet del Ministerio de Transportes y Comunicaciones: http://transparencia.mtc.gob.pe/idm_docs/Resoluciones_Viceministeriales/1321 9.pdf 


\section{BIBLIOGRAFÍA}

Acosta, O. L., Rozas Balbontín, P. \& Silva, A. (2008). Desarrollo vial e impacto fiscal del sistema de concesiones en Colombia. Santiago de Chile: División de Recursos Naturales e Infraestructura, Cepal.

Barrionuevo Luna, A. y Watanabe A. (2015). Demora en la entrega de predios necesarios para la ejecución de proyectos viales concesionados (Tesis de Maestría, Universidad del Pacífico, Lima, Perú). Recuperada de http://hdl.handle.net/11354/1124

Bull, A. (2004). Concesiones viales en América Latina: situación actual y perspectivas. Santiago de Chile: Cepal.

Coordinación de Concesiones de Obras Públicas. (2015). Sistema de Concesiones en Chile. Recuperado del sitio de Internet del Ministerio de Obras Públicas: http://www.mop.cl/participacion_ciudadana/Documents/cosoc/actas/ANEX O_SESION_7_N_1_COSOC_MOP_10122015.pdf

De la Torre, A. y Rudolph, H. (29 de marzo de 2016). Los Siete Pecados de Alianzas Público-Privadas Deficientes. Banco Mundial, p. 2.

Guasch, J. (2005). Concesiones de infraestructura. Cómo hacerlo bien. Barcelona: Antoni Bosch.

La Contraloría General de la República. (2015). Causas y efectos de las renegociaciones contractuales de las Asociaciones Público-Privadas en el Perú. Lima: Marena Morel

Menchola Arana, M. (2016). El Riesgo de Diseño en los Contratos de Concesión de Infraestructura Vial. Círculo de Derecho Administrativo, Núm. 16, 61-74.

Montoya, P. (2010). Concesiones de infraestructura vial. Lima: Dirección General de Concesiones en Transportes, Viceministerio de Transportes, MTC.

OECD (2015), Multi-dimensional Review of Peru: Volume 1. Initial Assessment [Estudio Multidimensional del Perú. Volumen 1. Evaluación inicial], OECD Publishing, Paris. DOI: http://dx.doi.org/10.1787/9789264243279-en

Pietro Barragán, T. (julio, 2015). Las Asociaciones Público-Privadas en el Perú: condiciones actuales y retos. Administración pública y control, Núm. 19, 6267.

Zecenarro, C. (2017). Comentarios a las novedades que trae el D. L. 1330, que modifica la Ley Marco de adquisiciones y expropiaciones para proyectos de infraestructura. Legis.pe. Recuperado de: http://legis.pe/comentarios-a-lasnovedades-que-trae-el-d-1-1330-que-modifica-la-ley-marco-deadquisiciones-y-expropiaciones-para-proyectos-de-infraestructura/ 
ANEXOS 


\section{Anexo A: Proyecto de Ley}

\section{PRESENTACIÓN.}

Los ciudadanos, a iniciativa de en ejercicio de su derecho de iniciativa que le confiere el artículo $107^{\circ}$ de la Constitución Política del Perú y la Ley N. ${ }^{\circ} 26300$, Ley de los Derechos de Participación y Control Ciudadanos.

\section{TÍTULO}

Ley que modifica el Decreto Legislativo N. 1192 , que aprueba la Ley Marco de Adquisición y Expropiación de Inmuebles, Transferencia de Inmuebles de Propiedad del Estado, Liberación de Interferencias y dicta otras medidas para la ejecución de obras de infraestructura

\section{FÓRMULA LEGAL.}

\section{Artículo 1.- Modificación de artículos del Decreto Legislativo No 1192}

Modifíquese los artículos 4, 5, 6, 12, 16, 21 y 23 del Decreto Legislativo $\mathrm{N}^{\mathrm{o}}$ 1192, en los siguientes términos:

\section{“Artículo 4.- Definiciones}

4.8-A Postores: Son posibles inversionistas que participan en los procesos de promoción de la inversión privada, en competencia y con igualdad de trato, con el fin de evitar conductas anticompetitivas o colusorias."

\section{“Artículo 5.- Del Beneficiario y el Sujeto Activo}

5.6. Tratándose de Obras de Infraestructura vial a ser ejecutadas mediante el mecanismo de asociaciones público privadas, el Sujeto Activo está facultado para realizar los procesos de reubicación o reasentamiento que permitan la liberación y saneamiento de terrenos y predios. Los procesos de reubicación o reasentamiento se deberán ejecutar 
de acuerdo a lo establecido en las Directrices para la Elaboración y Aplicación de Planes de Compensación y Reasentamiento Involuntario para Proyectos de Infraestructura de Transporte."

“Artículo 6.- Del Sujeto Pasivo en bienes inmuebles inscritos

6.3. Tratándose de bienes de dominio privado del Estado, el Sujeto Pasivo es el poseedor con más de diez años de antigüedad que tenga título de posesión inscrito, o cuya posesión se haya originado en mérito a resolución judicial o administrativa, o mediante certificado, constancia o documento que acredite la posesión emitido por la autoridad competente, de conformidad con la Ley N. ${ }^{\circ} 29618$, Ley que establece la presunción de que el Estado es poseedor de los inmuebles de su propiedad y declara imprescriptibles los bienes inmuebles de dominio privado estatal. En estos casos, el poseedor adjunta documentación en calidad de prueba complementaria."

\section{“Artículo 12.- Órgano encargado de la Tasación

12.2. En forma alternativa a lo dispuesto en el presente artículo, se autoriza al Ministerio de Transportes y Comunicaciones, por un plazo de cinco años contados a partir del 23 de julio de 2018, a solicitar la elaboración de la Tasación de los inmuebles necesarios para la ejecución de sus proyectos de infraestructura, a Peritos u organismos especializados en el rubro, con reconocida y acreditada experiencia. El procedimiento de tasación se ajustará a lo establecido en el Reglamento Nacional de Tasaciones y la normatividad vigente. Los organismos especializados a cargo del servicio de tasación serán solidariamente responsables con el Perito a cargo de la elaboración de la Tasación. El Ministerio de Transportes y Comunicaciones, mediante resolución ministerial emitirá las disposiciones complementarias necesarias; así como, establecerá las penalidades y/o sanciones, en caso los peritos $\mathrm{y} / \mathrm{u}$ organismos especializados no cumplan con las disposiciones establecidas en el Reglamento Nacional de Tasaciones.”

“Artículo 16.- Identificación de los inmuebles materia de Adquisición 


\section{$(\ldots)$}

16.5. Tratándose de Obras de Infraestructura vial a ser ejecutadas mediante el mecanismo de asociaciones público privadas, cofinanciadas o autofinanciadas, la identificación de los inmuebles debe completarse a la fecha de cierre de la fase de estructuración de la Asociación Público Privada.

Si el Sujeto Activo no puede identificar la totalidad de los predios necesarios para la ejecución del proyecto, a la fecha de cierre de la fase de estructuración del proceso de promoción de la inversión privada, los postores podrán colaborar con el Sujeto Activo, para identificar los bienes inmuebles restantes, antes del cierre de la fase de transacción, y de acuerdo a lo que disponga el organismo de promoción de la inversión privada."

\section{“Artículo 21.- Sobre los acuerdos de Adquisición}

\section{$(\ldots)$}

21.5. El Sujeto Activo puede celebrar contratos preparatorios o demás pactos permitidos por el Código Civil, con el propósito de obtener la posesión anticipada de los bienes inmuebles, para lo cual puede efectuar un pago hasta por el monto equivalente al cincuenta por ciento del Valor Estimado del Inmueble, el mismo que se considera como pago a cuenta del valor de la Tasación, previa certificación de disponibilidad presupuestal para financiar el pago del Valor Estimado del Inmueble. En este supuesto, el Sujeto Activo debe solicitar el bloqueo registral ante el Registro de Predios de la Sunarp, la misma que tendrá una vigencia máxima de dos años o hasta que el Sujeto Activo informe que ha culminado el proceso de Adquisición, lo que ocurra primero.

Tratándose de Obras de Infraestructura vial a ser ejecutadas mediante el mecanismo de asociaciones público privadas, el Sujeto Pasivo podrá cuestionar vía arbitral o judicial el valor de tasación final del bien inmueble siempre que, con la suscripción de contratos preparatorios o demás pactos, el Sujeto Pasivo efectúe la entrega anticipada de la posesión de los inmuebles." 


\section{“Artículo 23.- Adquisición a cargo del inversionista privado}

23.1. El organismo promotor de la inversión privada evalúa y determina en los respectivos contratos de asociación público privada el régimen aplicable a las Adquisiciones y Expropiaciones de inmuebles por parte del inversionista.

23.2. Tratándose de contratos en los cuales el Sujeto Activo no pueda entregar la totalidad de los predios necesarios para la ejecución del proyecto a la fecha de cierre del proceso de promoción de la inversión privada, dichos contratos pueden establecer que la elaboración de los expedientes técnicos legales serán realizados por el inversionista durante la etapa de elaboración de los estudios definitivos y entregados al Sujeto Activo en el plazo máximo determinado por el organismo promotor de la inversión privada respectivo.

23.3. En caso el contrato lo disponga, el inversionista efectuará la implementación, gestión y/o culminación del proceso de Adquisición por trato directo, procesos de reubicación o reasentamiento, y liberación de Interferencias, conforme a lo previsto en el presente Decreto Legislativo. En dicho caso, el inversionista privado se obliga a obtener la propiedad del inmueble, a favor del Beneficiario, mediante Adquisición por trato directo.

Tratándose de Obras de Infraestructura vial a ser ejecutadas mediante el mecanismo de asociaciones público privadas, el inversionista podrá conformar o contratar una entidad especializada en gestión predial, tanto para la elaboración de los expedientes técnico legal, tasación de los bienes inmuebles y gestión del trato directo, procesos de reubicación o reasentamiento; que cumpla con perfiles adecuados en cuanto a idoneidad, competencia y experiencia en la adquisición de predios para proyectos de infraestructura. La entidad especializada contratada por el inversionista, y éste último, serán solidariamente responsables, y deberán actuar conforme a los lineamientos establecidos para el Procedimiento de Adquisición. El Ministerio de Transportes y Comunicaciones, mediante resolución ministerial emitirá las disposiciones complementarias necesarias, por las que se establecerá los criterios de selección de los profesionales o de la entidad especializada en gestión predial, se identificará el organismo 
sobre el que recaerá la función de supervisión del inversionista, y se decidirá si se aplicarán penalidades en caso de incumplimientos.

\section{$(\ldots)$}

23.7. Una vez que el inversionista informe el agotamiento de las gestiones para adquirir el inmueble por Adquisición o transcurrido el plazo establecido en esta norma, el Sujeto Activo inicia el proceso de Expropiación. Para tales efectos, el inversionista presenta un informe sustentado al Sujeto Activo, incluyendo los documentos que acrediten el agotamiento de la Adquisición por trato directo.

Tratándose de Obras de Infraestructura vial a ser ejecutadas mediante el mecanismo de asociaciones público privadas, en el contrato se podrá establecer que el inversionista colaborará con el Sujeto Activo en el procedimiento de Expropiación preparando los informes y/o documentos establecidos en el Título IV; así como, realizando los pagos consignatarios, los mismos que le serán reembolsados por el Sujeto Activo según las condiciones establecidas en el numeral 23.5 del presente artículo.”

\section{EXPOSICIÓN DE MOTIVOS.}

\section{A. FUNDAMENTO DE LA PROPUESTA:}

Las propuestas formuladas tienen como propósito principal dictar medidas que permitan optimizar los procedimientos de adquisición y expropiación de inmuebles de para la pronta ejecución de los proyectos de infraestructura vial a ser ejecutadas mediante el mecanismo de asociaciones público privadas, de manera ágil y que permita destrabar los problemas que actualmente retrasan la ejecución de dichas obras en el territorio nacional. En ese sentido, el presente proyecto de ley no contraviene la constitución Política del Perú ni la legislación vigente.

\section{B. EFECTOS DE LA VIGENCIA DE LA NORMA:}

A continuación, analizaremos las propuestas legislativas planteadas: 


\section{(i) La definición de "Postores"}

Este cambio tiene por objetivo aplicar de mejor forma el Decreto Legislativo N. ${ }^{\circ} 1192$ (2015), se ha introducido la definición de “postores”, la cual se ha precisado conforme a lo descrito en el Decreto Legislativo N. ${ }^{\circ} 1362$ (2018). En el inciso 1., numeral 4.1., artículo 4 del Decreto Legislativo N. ${ }^{\circ}$ 1362 (2018) se precisa que: “1. Competencia: Los procesos de promoción de la inversión privada promueven la competencia e igualdad de trato entre los postores, y evitan conductas anticompetitivas o colusorias."

Entonces, la definición de postores desarrollada en el Decreto Legislativo N. ${ }^{\circ} 1192$ (2015), se encuentra en armonía con el concepto derivado del Decreto Legislativo N. ${ }^{\circ} 1362$ (2018).

\section{(ii) Precisión de las facultades del Beneficiario y el Sujeto Activo}

Este cambio tiene por objetivo adecuar el Decreto Legislativo N. ${ }^{\circ} 1192$ (2015), el Decreto Legislativo N. ${ }^{o}$ 1362(2018) y las Directrices para la Elaboración y Aplicación de Planes de Compensación y Reasentamiento Involuntario para Proyectos de Infraestructura de Transporte, poniéndolas en armonía para que contribuyan con la celeridad de la gestión predial.

Las Directrices para la Elaboración y Aplicación de Planes de Compensación y Reasentamiento Involuntario para Proyectos de Infraestructura de Transporte han sido reguladas por el MTC en el 2004; sin embargo, no fueron consideradas por el Decreto Legislativo N. ${ }^{\circ} 192$ (2015), ni las derogadas normas que regulaban las concesiones viales, el Decreto Legislativo N. 1012 (2008) y su reglamento, el Decreto Supremo N. ${ }^{\circ} 127$ 2014-EF (2014); y el Decreto Legislativo N. ${ }^{\circ} 1224$ (2015) y su reglamento, el Decreto Supremo N. ${ }^{\circ}$ 410-2015-EF (2015). A diferencia de las normas mencionadas, el Decreto Legislativo N. ${ }^{\circ} 1362$ (2018) sí ha precisado que el MTC se encuentra facultado de ejecutar el PACRI., cuando sea necesario. Aunque no se haya establecido mayor detalle, esto permitirá promocionar el PACRI entre las futuras concesiones viales, lo que optimizará la gestión predial pues se podrán prevenir el rechazo social, facilitará la inspección ocular de las viviendas, facilitará la realización de tasaciones, y mejorará las 
condiciones de negociación entre el sujeto activo y sujeto pasivo de la gestión predial.

(iii) Precisión para determinar al Sujeto Pasivo de bienes inmuebles inscritos

Este cambio normativo tiene por objetivo aclarar que no son Sujetos Pasivos los poseedores con menos de diez años sobre bienes de derecho privado estatal, de conformidad con la Ley N. 29618 (2010), Ley que establece la presunción de que el Estado es poseedor de los inmuebles de su propiedad y declara imprescriptibles los bienes inmuebles de dominio privado estatal, publicada el 24 de noviembre de 2010. En ese sentido, los poseedores cuyo plazo de prescripción haya iniciado antes de la publicación de la Ley N. ${ }^{\circ}$ 29618 (2010), sí podrán ser considerados Sujetos Pasivos de la gestión predial; mientras que, los poseedores cuyo plazo de prescripción haya iniciado con fecha posterior a la Ley N. 29618 (2010), no serán considerados Sujetos Pasivos de la gestión predial, y, por tanto, sobre ellos se iniciará el proceso de desalojo y, de corresponder, un pago por las edificaciones realizadas en el inmueble privado estatal.

\section{(iv) Precisiones sobre los órganos encargados de la tasación}

Este cambio normativo tiene por objetivo complementar las modificaciones realizadas por el Decreto Legislativo N. ${ }^{\circ} 1366$, por el cual se autoriza al Ministerio de Transportes y Comunicaciones, por un plazo de cinco años contados a partir de la publicación del citado Decreto Legislativo, a solicitar la elaboración de la Tasación de los inmuebles necesarios para la ejecución de sus proyectos de infraestructura, a Peritos u organismos especializados en el rubro, con reconocida y acreditada experiencia. Ante ello, se señaló en la misma norma que, el Ministerio de Transportes y Comunicaciones, mediante resolución ministerial emitirá las disposiciones complementarias necesarias. Poco tiempo después se publicó la Resolución Ministerial 763-2018-MTC/01; sin embargo, esta norma no considera las medidas a tomar en caso los peritos y/u organismos especializados no cumplan con las disposiciones establecidas en el Reglamento Nacional de Tasaciones. 
Esta adición normativa tiene por objetivo optimizar la gestión predial en las de Obras de Infraestructura vial a ser ejecutadas mediante el mecanismo de asociaciones público privadas, cofinanciadas o autofinanciadas, estableciendo como fecha máxima para la identificación de predios el cierre de la fase de estructuración del proceso de promoción de la inversión privada. Así mismo, se brinda la posibilidad de que sean los postores quienes, con su experiencia y tecnología, puedan colaborar con el Sujeto Activo para lograr la identificación de los bienes inmuebles restantes, en la fase de transacción del proceso de promoción de la inversión privada.

\section{(vi) Precisión sobre los acuerdos de Adquisición}

Esta adición normativa tiene por objetivo optimizar la gestión predial en las de obras de infraestructura vial a ser ejecutadas mediante el mecanismo de asociaciones público privadas, proponiendo una nueva alternativa de negociación que promueva la entrega anticipada del bien inmueble deseado. Esta brinda la posibilidad de que Sujeto Pasivo discuta el valor compensatorio por la vía judicial o arbitral, mientras dispone de un porcentaje del dinero correspondiente a la indemnización compensatoria, tasada en primera instancia.

Con relación al porcentaje con el que podrá disponer el Sujeto Pasivo, se brinda solo el cincuenta por ciento con el fin de incentivar al Sujeto Pasivo de realizar la entrega anticipada del bien inmueble voluntariamente y sin recurrir al procedimiento de expropiación, gozando del incentivo adicional del veinte por ciento sobre el valor de tasación; pues, si se entregase el cien por ciento del valor de tasación, se incentivaría a más a Sujetos Pasivos no suscribir el trato directo y a cuestionar vía judicial o arbitrar el valor de tasación final.

En Chile, mientras se desarrolla el proceso de expropiación judicial, el juez puede ordenar que se pague al propietario expropiado la suma no disputada del monto de indemnización; así como, se puede autorizar al Ministerio de Obras Públicas (Entidad que representa al Estado Chileno en las 
Expropiaciones) para que ingrese a terreno y ejecute las obras a pesar del procedimiento judicial en trámite.

(vii) Adiciones a las funciones del inversionista privado que está a cargo de la Adquisición

Con estos cambios se busca promover que el organismo promotor de la inversión privada involucre más al inversionista en la gestión predial de las obras de Infraestructura vial a ser ejecutadas mediante el mecanismo de asociaciones público privadas.

Considerando lo descrito, en el numeral 23.1. se ha propuesto que el organismo promotor de la inversión privada evalúe y determine en cada contrato de concesión vial, sobre el régimen aplicable a las Adquisiciones y Expropiaciones de inmuebles, por parte del inversionista.

Se ha aclarado en el numeral 23.2. que es el Sujeto Activo (Ministerio competente del sector, el Gobierno Regional y el Gobierno Local) el responsable de entregar la totalidad de los predios necesarios para la ejecución del proyecto, pues antes se señalaba que era el Estado, de manera general.

En ese sentido, se ha modificado el numeral 23.3, y se ha establecido que el inversionista sea quien conforme o contrate una entidad especializada en gestión predial, tanto para la elaboración de los expedientes técnico legal, tasación de los bienes inmuebles y gestión del trato directo, procesos de reubicación o reasentamiento; siempre que, dichos profesionales cuenten con perfiles adecuados en cuanto a idoneidad, competencia y experiencia en la adquisición de predios para proyectos de infraestructura, en zonas urbanas y rurales.

Como se mencionó, la Primera Disposición Complementaria Final del Decreto Legislativo N. ${ }^{\circ}$ 1366, autorizó al Ministerio de Transportes y Comunicaciones a solicitar la elaboración de la tasación de los inmuebles necesarios para la ejecución de sus proyectos de infraestructura, a peritos u organismos especializados en el rubro, con reconocida y acreditada experiencia. En ese sentido, resulta conveniente que se pueda facultar al concesionario la realización de actividades correspondientes al procedimiento 
de adquisición; facultades que deberán ser delimitadas mediante resolución ministerial que emitirá el Ministerio de Transportes y Comunicaciones.

Finalmente, el cambio propuesto para el numeral 23.7 tiene por objetivo permitir y promover la participación del inversionista en el procedimiento de expropiación, a través de la elaboración de informes o documentos establecido en el Título IV. Así como, se propone que el inversionista impulse el procedimiento de expropiación realizando los pagos consignatarios, al igual como se le ha facultado en el numeral 23.5 del artículo 23 del mismo Decreto Legislativo N. ${ }^{\circ} 1192$, es decir, reembolsando los gastos en los que haya incurrido el inversionista para lograr obtener la titularidad de los inmuebles.

De lo analizado, podemos concluir que los cambios normativos propuestos fortalecen el Decreto Legislativo N. ${ }^{\circ}$ 1192, Ley Marco de Adquisición y Expropiación de inmuebles, transferencia de inmuebles de propiedad del Estado, liberación de Interferencias y dicta otras medidas para la ejecución de obras de infraestructura, y no contravienen con la normatividad vigente.

\section{ANÁLISIS COSTO BENEFICIO:}

De acuerdo con la justificación expuesta para cada cambio normativo, las modificaciones planteadas al Decreto Legislativo N. ${ }^{\circ}$ 1192, son medidas que no tendrán costos que impactarán sobre el presupuesto público. Por el contrario, permitirá optimizar los procedimientos de adquisición y expropiación en obras públicas de infraestructura vial, acelerar la entrega de los predios concesionados, y ejecutar las obras de infraestructura vial requeridas; lo cual redunda en el beneficio general del país, al mejorar las vías de transporte, que impulsan el comercio, turismo, comunicación, la educación, los avances tecnológicos y el desarrollo en otros sectores económicos. 